Paula Marzorati Kuntz Puglia

\title{
PORFIRIA AGUDA INTERMITENTE: Estudo CLínICO dE 37 CASOS
}

\author{
Dissertação apresentada à Faculdade de \\ Medicina da Universidade de São Paulo \\ para obtenção do Título de Mestre em \\ Neurologia \\ Área de Concentração: Neurologia \\ Orientador: Prof. Dr. Paulo Eurípedes \\ Marchiori
}




\section{DEDICATÓRIA}



Ao Paulo e à minha família 


\section{AGRADECIMENTOS}


Ao orientador Prof. Dr. Paulo Marchiori pelo estímulo e pelas valiosas orientações

À Dra. Georgina, pelo intercâmbio de informações e pelo auxílio na convocação dos pacientes

Aos funcionários da Eletroneuromiografia e do Arquivo pela ajuda no levantamento de exames e de prontuários

Aos amigos do Departamento de Neurologia e do Serviço de Eletroneuromiografia pelo apoio prestado

Aos funcionários do Departamento de Neurologia, em especial ao Erli e à Sueli, pela eficiência e dedicação com que desempenharam o seu trabalho

Aos amigos do Serviço de Explorações Funcionais do Hospital La Pitié Salpêtrière pelo interesse demonstrado e pelo estímulo fundamentais para a conclusão deste trabalho

Às bibliotecárias da Biblioteca Charcot do Hospital La Pitié Salpêtrière pela ajuda no levantamento bibliográfico

A todos aqueles que se dedicaram a preencher os prontuário dos pacientes da forma mais completa possível 


\section{SUMÁRIO}

Lista de Abreviaturas

Lista de Tabelas

Lista de Figuras

Resumo

Summary

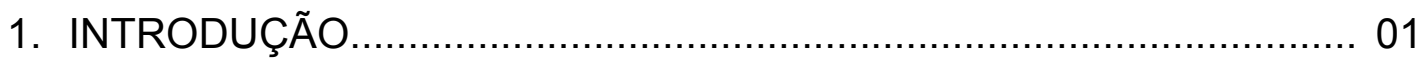

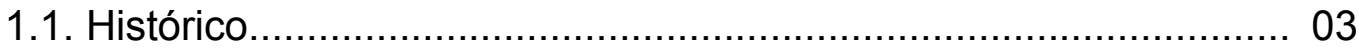

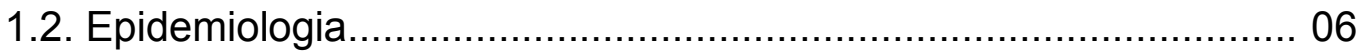

1.2.1. Idade e Sexo........................................................... 06

1.2.2. Incidência e Prevalência............................................. 07

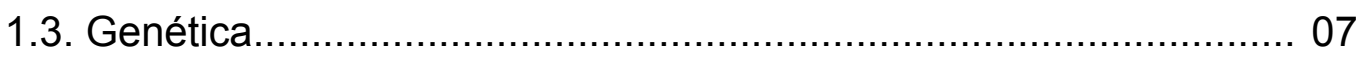

1.4. Biossíntese do Heme e Alterações Metabólicas.......................... 09

1.5. Fatores Precipitantes...................................................... 17

1.5.1. Medicamentos e Outras Substâncias Químicas................ 20

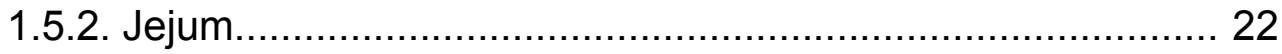

1.5.3. Fatores Hormonais......................................................... 24

1.5.4. Outros................................................................. 26

1.6. Quadro Clínico.............................................................. 27

1.6.1. Manifestações Neurovegetativas.................................. 28

1.6.1.1. Gastro-Intestinais........................................ 28

1.6.1.2. Cardiovasculares e Respiratórias....................... 30

1.6.1.3. Distúrbios Esfincterianos..................................... 31

1.6.2. Manifestações do Sistema Nervoso Periférico................... 31

1.6.3. Manifestações do Sistema Nervoso Central..................... 35

1.6.4. Manifestações Psiquiátricas......................................... 36

1.6.5. Manifestações Sistêmicas.......................................... 37

1.6.6. Diagnóstico Diferencial............................................. 39

1.6.7. Evolução......................................................................... 42

1.6.8. Doenças Associadas...................................................... 44 
1.7. Etiopatogenia................................................................... 45

1.7.1. Deficiência de Heme nos Tecidos Neurais........................ 46

1.7.2. Neurotoxicidade Devido ao Acúmulo de Precursores das 48 Porfirinas (ALA e PBG)

1.7.3. Depleção de Substratos Essenciais ou de Co-Fatores. 54

1.7.4. Acúmulo de Produtos Anormais Derivados dos Precursores das Porfirinas........................................... 57

1.7.5. Outras Hipóteses...................................................... 57

1.8. Neuropatologia.......................................................... 59

1.8.1. Nervos Periféricos................................................. 59

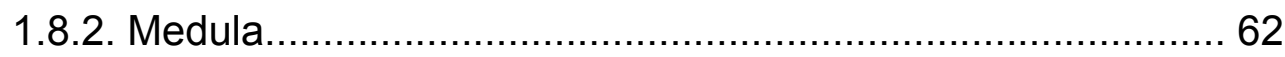

1.8.3. Sistema Neurovegetativo...................................... 62

1.8.4. Encéfalo.................................................................. 63

1.9. Fisiopatologia ............................................................... 64

1.9.1. Sistema Neurovegetativo........................................ 64

1.9.2. Sistema Nervoso Periférico.......................................... 67

1.9.3. Sistema Nervoso Central e Manifestações Psiquiátricas..... 68

1.9.4. Manifestações Sistêmicas............................................ 70

1.10. Diagnóstico............................................................... 72

1.10.1. Bioquímico.......................................................... 72

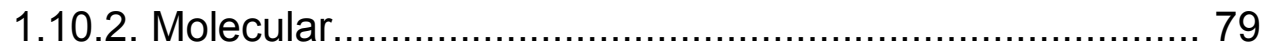

1.10.3. Eletrofisiológico................................................... 80

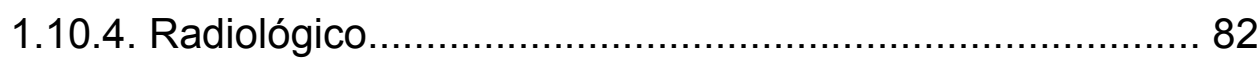

1.11. Tratamento................................................................... 83

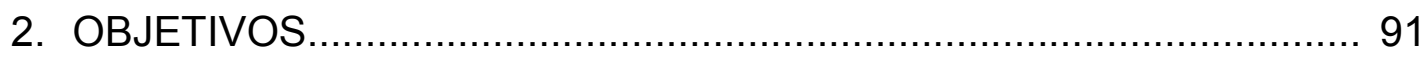

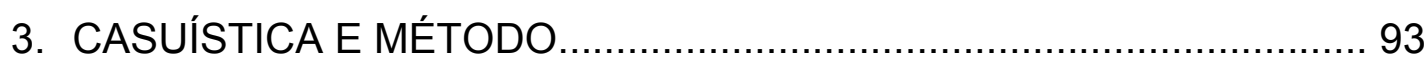

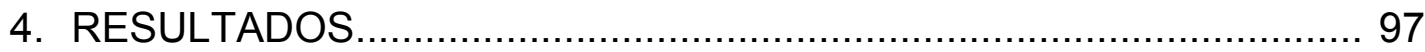

4.1. Características do Grupo Estudado........................................ 98

4.2. Manifestações Clínicas........................................................ 99

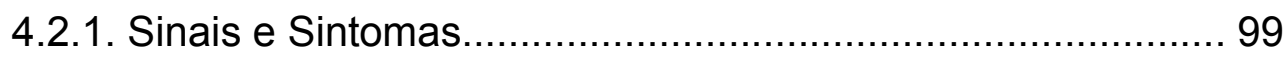

4.2.2. Número e Intensidade das Crises.............................. 112 
4.2.3. Fatores Precipitantes................................................. 116

4.2.4. Diagnóstico.............................................................. 120

4.2.5. Tratamento e Prognóstico........................................... 122

4.2.6. Doenças Associadas.................................................. 123

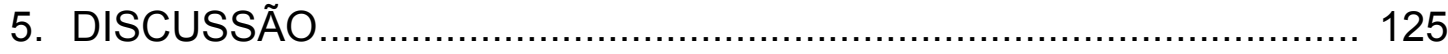

5.1. Grupo Estudado.............................................................. 126

5.1.1. Idade e Sexo........................................................ 126

5.1.2. Antecedente Familiar............................................... 128

5.2. Manifestações Clínicas.......................................................... 130

5.2.1. Sinais e Sintomas.................................................. 130

5.2.1.1. Quadro Clínico Inaugural................................ 130

5.2.1.2. Características das Manifestações Clínicas............ 133

5.2.2. Freqüência e Gravidade das Crises............................... 144

5.2.3. Fatores Precipitantes.............................................. 147

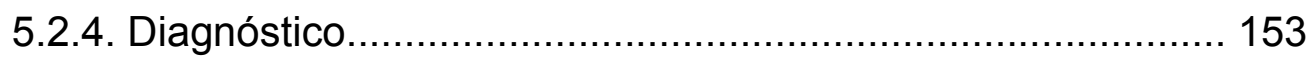

5.2.5. Tratamento, Evolução e Prognóstico................................ 160

5.2.6. Doenças Associadas.................................................. 163

6. CONCLUSÕES .................................................................... 164



8. REFERÊNCIAS BIBLIOGRÁFICAS .......................................... 177 


\section{Lista de Abreviaturas}

\begin{tabular}{ll} 
ADN & Ácido desoxirribonucleico \\
ALA & Ácido $\delta$-aminolevulínico \\
ALA-S & Ácido $\delta$-aminolevulínico-sintetase \\
ALA-D & Ácido $\delta$-aminolevulínico-dehidratase \\
ATP & Adenosina trifosfato \\
Ca ${ }^{++}$ & Cálcio \\
CPH & Coproporfiria hereditária \\
COPRO & Coproporfirina \\
CRIM & "Cross reacting immunological material" \\
D-ALA-D & Deficiência de ALA-dehidratase \\
EDTA & Ácido etilenodiamino tetraacético \\
GABA & Ácido gama-amino-butírico \\
HAD & Hormônio anti-diurético \\
HPLC & Cromatografia líquida de alta performance \\
PAI & Porfiria aguda intermitente \\
Pb & Chumbo \\
PBG & Porfobilinogênio \\
PCT & Porfiria cutânea tarda \\
PEC & Porfiria eritropoiética congênita \\
PPE & Protoporfiria eritropoiética \\
PV & Porfiria variegada \\
RM & Ressonância magnética \\
SIHAD & Síndrome de secreção inapropriada de hormônio anti- \\
SNC & diurético \\
SNP & Sistema nervoso central \\
SNV & Sistema nervoso periférico \\
URO-S & Sistema neurovegetativo \\
URO & Uroporfirinogênio-l-sintetase \\
& Uroporfirina \\
\hline SA &
\end{tabular}


$\mathrm{Zn}$

Zinco

\section{Lista de Tabelas}

Tabela $1 \quad$ Número de crises com acometimento do sistema nervoso periférico e/ou sistema nervoso central....... 100

Tabela $2 \quad$ Alteração do ritmo intestinal.................................. 103

Tabela $3 \quad$ Alteração qualitativa da cor da urina......................... 104

Tabela 4 Alteração do nível de consciência ou confusão mental........................................................... 105

Tabela $5 \quad$ Crises convulsivas.......................................... 105

Tabela $6 \quad$ Manifestações psiquiátricas.................................. 106

Tabela $7 \quad$ Neuropatia motora ou sensitivo-motora.................. 106

Tabela $8 \quad$ Topografia do déficit motor predominante............... 108

Tabela $9 \quad$ Características das manifestações sensitivas.......... 109

Tabela 10 Comprometimento da ventilação........................... 110

Tabela 11 Fatores precipitantes...................................... 116

Tabela $12 \quad$ Fatores precipitantes nas crises graves.................. 117

Tabela 13 Fatores precipitantes nas crises leves................... 118

Tabela 14 Número de fatores precipitantes............................ 119

Tabela 15 Fatores precipitantes nas manifestações crônicas... 119

Tabela 16 Outras doenças ou condições associadas............... 124

Tabela 17 Sintomas e sinais nas diversas séries estudadas.... 134 


\section{Lista de Figuras}

Figura 1 Biossíntese do heme........................................ 12

Figura 2 Manifestações clínicas nas crises de PAl................ 99

Figura 3 Característica da dor abdominal e/ou lombar.......... 101

Figura 4 Localização da dor abdominal e/ou lombar............. 102

Figura 5 Duração da dor abdominal e/ou lombar.................. 103

Figura $6 \quad$ Número de pacientes $x$ número de crises............... 112

Figura $7 \quad$ Número de crises no sexo feminino....................... 112

Figura $8 \quad$ Número de crises no sexo masculino..................... 113

Figura 9 Distribuição das crises quanto à gravidade............ 113

Figura 10 Número de crises entre os pacientes com quadros graves..................................................... 115

Figura 11 Foto - Biópsia de nervo sural de paciente com PAI. 121

Figura 12 Tratamento instituído em 63 crises......................... 122

Figura 13 Algoritmo para diagnóstico de PAl......................... 156 


\section{RESUMO}


Puglia, Paula Marzorati Kuntz. Porfiria aguda intermitente: estudo clínico de 37 casos. São Paulo, 2001. Dissertação (mestrado) - Faculdade de Medicina da Universidade de São Paulo. Departamento de Neurologia

A porfiria aguda intermitente é uma doença autossômica dominante, decorrente de um distúrbio na via biossintética do heme, causado pela redução dos níveis da enzima uroporfirinogênio-I-sintetase. As manifestações clínicas envolvem o sistema nervoso periférico e o central. O diagnóstico baseia-se na excreção urinária elevada dos precursores das porfirinas ácido $\delta$-aminolevulínico e porfobilinogênio. O objetivo deste estudo foi analisar o quadro clínico apresentado por pacientes do Hospital das Clínicas de São Paulo com porfiria aguda intermitente, atendidos no período de janeiro de 1979 a dezembro de 1999. Foram avaliados 37 pacientes, com idades entre 6 e 48 anos, na proporção de 2,7 mulheres:1 homem. A faixa etária na qual ocorreu o maior número de crises foi a terceira década. Os pacientes apresentaram 63 crises, sendo que 13 deles também tiveram manifestações de caráter crônico. As manifestações clínicas mais freqüentes foram: dor abdominal, alteração da cor da urina, mudança no ritmo intestinal, déficit motor ou sensitivo-motor, vômitos, alteração do nível de consciência ou confusão mental, crises convulsivas, quadros disautonômicos cardio-vasculares e distúrbios psiquiátricos. As crises foram classificadas em leves, moderadas e graves, segundo critérios previamente estabelecidos. Todas as manifestações crônicas foram caracterizadas como leves. A neuropatia periférica motora ou sensitivo-motora nunca foi a manifestação inicial da crise de porfiria aguda intermitente. Houve correlação entre o tipo e o número de fatores precipitantes e a manifestação da neuropatia periférica motora ou sensitivomotora, verificando-se que as crises nas quais ela está ausente foram em geral desencadeadas por apenas um fator, mais comumente de origem endócrina ou metabólica endógena, como período menstrual e jejum, enquanto que nas crises com neuropatia periférica houve a participação de vários fatores concomitantemente, sendo estes principalmente de origem exógena, como medicamentos. Os tratamentos mais utilizados nos surtos foram a administração de glicose, aumento da ingestão de carboidratos e o uso de fenotiazínicos. 
SUMMARY 
Puglia, Paula Marzorati Kuntz. Acute intermittent porphyria: clinical study of $\mathbf{3 7}$ cases. São Paulo, 2001. Dissertação (mestrado) - Faculdade de Medicina da Universidade de São Paulo. Departamento de Neurologia

Acute intermittent porphyria is an autosomal dominant disease, caused by a disturbance in the heme biosynthetic pathway, secondary to the reduction on the levels of uroporphyrinogen-I-synthetase enzyme. Clinical manifestations involve central and peripheral nervous system. The diagnosis is based on the elevated urinary excretion of porphyrins precursors $\delta$-aminolevulinic acid and porphobilinogen. The aim of this study was to analyze the clinical manifestations of acute intermittent porphyria in patients of the Hospital das Clínicas of São Paulo, seen between January 1979 and December 1999. 37 patients were studied, from 6 to 48 years old, with a rate of 2,7 women: 1 man. The age in which most of the crisis occurred was the third decade. The patients presented 63 crisis, and 13 of them presented also with chronic manifestations. The commonest clinical presentations were: abdominal pain, change in urine color, change in bowel habits, motor or sensory-motor deficit, vomiting, alteration of consciousness or mental confusion, convulsions, dysautonomic cardiovascular signs and psychiatric disorders. The crisis were classified as mild, moderate and severe, following criteria previously established. All chronic manifestations were characterized as mild. The peripheral motor or sensory-motor neuropathy was never the initial manifestation. Correlation was found between the kind and the number of precipitating factors, and the absence of peripheral neuropathy was in general related to just one factor, more commonly of endogenous endocrine or metabolic origin, like menstrual period and starvation, while in the crisis with peripheral neuropathy multiple factors were involved at the same time, these being of exogenous origin, like drugs. The most commonly used treatments were glucose administration, elevation of carbohydrate intake, and phenothiazines use. 
1. INTRODUÇÃO 
Porfirias são doenças causadas por distúrbios na síntese do heme, conseqüentes a defeitos enzimáticos específicos nesta via, geralmente em associação com fatores desencadeantes endógenos ou exogénos ${ }^{37}$. É um grupo de doenças heterogêneo, com características clínicas e bioquímicas peculiares a cada uma delas. São relativamente raras, e podem ser herdadas, ou, menos comumente, adquiridas. Há sete formas de porfiria reconhecidas atualmente, sendo classificadas segundo o respectivo defeito enzimático e perfil bioquímico encontrado nos tecidos, na urina, no sangue e nas fezes do indivíduo. Baseado no conteúdo da porfirina ou do seu precursor no tecido no qual o distúrbio metabólico predomina (fígado ou medula óssea), classificam-se as porfirias em dois grupos: eritropoiéticas e hepáticas $^{168}$. As eritropoiéticas compreendem a porfiria eritropoiética congênita (PEC), ou Doença de Günther, e a protoporfiria eritropoiética (PPE). Dentre as hepáticas, encontram-se: porfiria aguda intermitente (PAI), porfiria variegada $(\mathrm{PV})$, coproporfiria hereditária $(\mathrm{CPH})$, deficiência de ácido $\delta$-aminolevulínico-dehidratase (D-ALA-D), ou porfiria de Doss, e porfiria cutânea tarda $(P C T)^{137,173}$. Além desta classificação, de acordo com o tecido onde o defeito metabólico expressa-se, há outra, baseada na apresentação clínica, de maior utilidade para fins diagnósticos, separando as porfirias em neurológicas (PAI, D-ALA-D) ou cutâneas (PPE, PCT, PEC), havendo ainda um terceiro grupo, com manifestações neurológicas e cutâneas (PV e CPH).

Neste estudo abordaremos especificamente a PAI, porfiria hepática com manifestações neurológicas, também conhecida como pirroloporfiria ou porfiria sueca, doença decorrente de erro inato do metabolismo das 
porfirinas, que caracteristicamente apresenta-se na forma de episódios recorrentes com remissão em dias ou semanas.

\subsection{HistóRICO}

O termo porfiria tem origem grega (Porphurus), e significa "púrpura". Foi inicialmente utilizado por FISCHER ${ }^{57}$ apud WATSON ${ }^{198}$ e posteriormente popularizado por WALDENSTRÖM ${ }^{194,195,196}$ em várias publicações sobre o tema. GÜNTHER ${ }^{75}$ foi o primeiro a conceber a existência de vários tipos de porfiria, nesta época ainda conhecida como "hematoporfiria". WALDENSTRÖM ${ }^{194}$ foi o autor que caracterizou a PAI como "a pequena imitadora", em contraste com a sífilis, "a grande imitadora", por sua maior incidência, em referência à grande variedade de doenças que é capaz de mimetizar. Foi também responsável pela adoção do termo "porfiria aguda intermitente", apoiando-se no fato de que, apesar do distúrbio metabólico ser crônico, e estar presente desde o nascimento, apresenta-se em surtos agudos, demonstrando que esta doença é uma entidade com características bem definidas, separando-a das demais porfirias e das porfirinúrias sintomáticas. Estas últimas são definidas como condições que podem levar a um aumento da excreção das porfirinas por disfunção na síntese do heme, mas que não preenchem o padrão de excreção das porfirinas e seus precursores encontrado nas porfirias. São exemplos destas condições: ingestão excessiva de etanol, intoxicação por chumbo (Pb), hepatopatias e discrasias sangüíneas. 
Hipócrates foi provavelmente o primeiro a descrever um caso de porfiria $^{64,156,192}$, numa paciente proveniente da cidade de Thásos, com sintomas neurológicos e psiquiátricos, como crises convulsivas, sensação de terror, diminuição do nível de consciência, lipotimia, febre, e eliminação de urina escurecida, pouco antes da menstruação, seguidos de remissão completa e espontânea do quadro após três dias. A primeira descrição de porfiria relacionada à precipitação da crise por medicação é de STOKVIS ${ }^{175}$ apud SUAREZ et al. ${ }^{177}$, em 1889 , que relatou o caso de uma paciente com urina vermelho-escura, falecida após a ingestão de sulfometano. Em 1890 HARLEY ${ }^{77}$ descreveu dois episódios sugestivos de PAI, ambos também relacionados ao sulfometano, e, no mesmo ano, RANKING e PARDINGTON $^{151}$ relataram dois casos, definidos como hematoporfirinúria, sendo um deles fatal, não associados à ingestão de medicamentos. Desde então proliferaram monografias e descrições de $\operatorname{casos}^{66,75,99,113,174,197 .}$

WALDENSTRÖM ${ }^{193}$ conferiu o caráter de doença hereditária à PAI. A análise retrospectiva da eventual presença de porfiria aguda em membros da família real britânica ${ }^{110}$, e da família de Van $\operatorname{Gogh}^{86,108,176}$ - embora o diagnóstico de PAI neste último seja bastante controverso - demonstrou o padrão de hereditariedade da doença, característico pelo fato de poucos portadores do gene manifestarem a doença, apesar de poderem ser identificados através de exames bioquímicos.

CAMPBELL $^{28}$ apud YEUNG-LAIWAH et al. ${ }^{207}$, em 1898, foi o primeiro a descrever as alterações patológicas num caso de porfiria aguda, não conseguindo demonstrar qualquer lesão no sistema nervoso central (SNC). 
ERBSLÖH ${ }^{52}$ descreveu ineditamente os aspectos histopatológicos do nervo femoral de um caso fatal de porfiria que havia sido submetido a tratamento com sulfonal, revelando degeneração axonal e desmielinização segmentar. Após 30 anos, MASON et al. ${ }^{116}$ revisaram extensamente 0 assunto, buscando estabelecer uma relação entre o quadro clínico e os achados patológicos: realizaram autópsias em quatro casos, e concluíram que as alterações mais significativas encontravam-se no sistema nervoso, principalmente nos nervos periféricos e nos gânglios simpáticos do sistema neurovegetativo (SNV), mas também na ponta anterior da medula e no cerebelo. FISCHER ${ }^{57}$ apud WATSON ${ }^{198}$ contribuiu de maneira decisiva para a identificação de compostos envolvidos na fisiopatologia da PAI, isolando a uroporfirina (URO) e a coproporfirina (COPRO). Em 1931, SACHS ${ }^{162}$ observou que a urina de pacientes com PAI continha um cromógeno incolor Ehrlich-positivo, pois esta substância, em contato com o reagente de Ehrlich, adquire uma coloração vermelho-brilhante, chamada de porfobilinogênio (PBG). Este poderia ligar-se tanto à uroporfirina quanto a um pigmento chamado de porfobilina, fornecendo uma pista importante para o diagnóstico laboratorial da doença. WATSON e SCHWARTZ ${ }^{201}$ idealizaram a reação que leva os seus nomes, tornando rotineiro o diagnóstico de porfiria. GOLDBERG e RIMINGTON ${ }^{68}$ demonstraram que o porfobilinogênio é produzido no fígado, e SCHMID, SCHWARTZ e WATSON ${ }^{168}$, que a porfiria aguda intermitente é uma forma de porfiria hepática, ou seja, o distúrbio do metabolismo da porfirina tem origem no fígado. GRANICK e URATA ${ }^{72}$ mostraram que a ácido $\delta$-aminolevulínico-sintetase (ALA-S) é uma enzima 
hepática indutora da via biossintética do heme, com papel fundamental na etiopatogenia da PAI. Outros achados importantes foram a descoberta dos níveis alterados da enzima ALA-sintetase no fígado, por TSCHUDY et al. ${ }^{190}$, e da queda na conversão de PBG em porfirinas, decorrente da deficiência específica de uma enzima, a uroporfirinogênio-I-sintetase (URO-S), identificada na década de 70 por MEYER et al. ${ }^{125}$. TSCHUDY et al. ${ }^{190}$ demonstraram que a ingestão de carboidratos em grandes quantidades bloqueia a indução da ALA-sintetase nas porfirias hepáticas humana e experimental, e BONKOVSKY et al. ${ }^{23}$ foram os primeiros a utilizar hematina endovenosa no tratamento de um paciente, mostrando que este composto era capaz de suprimir o excesso de produção dos precursores da porfirina.

Em 1980 MEISLER et al. $^{122}$ identificaram o locus genético responsável pela codificação da enzima deficitária na PAI no cromossomo 11.

\subsection{EPIDEMIOLOGIA}

\subsubsection{IDADE E SEXo}

A PAl raramente manifesta-se antes da puberdade, tanto clínica quanto laboratorialmente. O pico de incidência do primeiro ataque ocorre entre os 20 e os 30 anos, e é incomum que o primeiro surto ocorra antes da primeira ou após a sexta década de vida ${ }^{197}$. A maioria das crises de PAI ocorre entre a terceira e quarta décadas. Predomina no sexo feminino, constatando-se uma relação de aproximadamente $1,4: 1$ na maior série estudada (321 pacientes) ${ }^{195}$ a 4,3:1 em uma série significativamente menor 



média 11 anos mais tarde que nas mulheres (aos 36 e aos 25 anos, respectivamente) $)^{174}$.

\subsubsection{InCIDÊnCIA E PREVALÊnCIA}

Os dados existentes a respeito da incidência e prevalência da PAI são extremamente variáveis de um país para outro. As estimativas indicam que é mais freqüente na Escandinávia, Inglaterra e Irlanda, sendo que na Lapônia, no norte da Suécia, a prevalência é de 1:1.000 habitantes. Na Finlândia, a incidência de deficiência de URO-S no sangue é de 1:500 indivíduos, sendo que somente alterações no tecido hepático são capazes de produzir o quadro de porfiria $^{132}$. Na Argentina, a prevalência estimada é de 1:125.000 indivíduos $^{42}$. Em geral, considera-se que a prevalência de pacientes com PAl é de 1 a $5 / 100.000$ habitantes $^{189}$, enquanto que a de portadores do gene

é estimada em $1 / 10.000^{89,128}$. Na maioria dos países estudados, a PAl é mais comum que os demais tipos de porfiria. Não há evidência de predomínio sazonal na incidência dos surtos ${ }^{153}$. Não há estudos a respeito no Brasil.

\subsection{GenÉticA}

A expressão do defeito genético em determinado tecido (fígado ou medula óssea), particular a cada porfiria, é em grande parte devida ao controle tecido-específico da expressão genética da via biossintética do 
heme ${ }^{166}$. A PAl é doença hereditária, com transmissão autossômica dominante e penetrância incompleta, de 10 a $20 \%{ }^{69,76,89}$, existindo graus variáveis de expressão, com quadros clínicos de gravidade diversa. Aproximadamente 80 a $90 \%$ dos indivíduos herdeiros do gene são apenas portadores, ou seja, permanecem latentes durante toda a vida, sem apresentarem manifestações clínicas.

O gene responsável pela transmissão da PAl é o que codifica a enzima URO-S, localizando-se na porção distal do braço longo do cromossomo $11^{122}$, nos locus 24.1 e $24.2^{135}$, e contém 15 exons. Sua seqüência já é totalmente conhecida ${ }^{208}$. A mutação genética causa redução de aproximadamente $50 \%$ na atividade da enzima URO-S, o que indica que o alelo mutante está associado com pouca ou nenhuma atividade, devido à deleção de apenas uma parte ou de todo o gene, ou pela produção de uma anormalidade estrutural no RNA mensageiro ou mesmo na proteína da enzima, que seria então rapidamente degradada. Existem duas isoformas da URO-S: uma expressa somente nos eritrócitos, e outra em todos os tecidos, diferindo da primeira pela adição de 17 aminoácidos ${ }^{51}$. Ambas são codificadas pelo mesmo gene, embora transcrito por diferentes promotores.

Estima-se que a maioria das mutações seja herdada, enquanto que apenas $3 \%$ dos casos de PAl são derivados de mutações genéticas "de novo"204. Foram descritas mais de 120 diferentes mutações no gene da URO-S ${ }^{51}$, e aproximadamente $40 \%$ destas mutações ocorrem nos exons 10 e 12, embora tenham sido encontradas mutações em quase todos os exons, assim como em vários introns. Estudos demonstram que as mutações 
assumem características próprias, dependendo da população estudada: na Finlândia $^{92}$, na República Tcheca e na Eslováquia ${ }^{160}$, são extremamente heterogêneas, enquanto que na Suécia existe um número limitado de mutações nas famílias observadas ${ }^{109}$. Não há correlação entre a severidade dos sintomas e o tipo de mutação, o que não surpreende, já tendo sido observado que numa mesma família a expressão clínica pode ser extremamente variável entre os indivíduos, e pode mesmo haver variação entre uma e outra crise, no mesmo paciente. É possível, por outro lado, que diferentes padrões genéticos modulem a sensibilidade individual a um determinado fator precipitante ${ }^{69}$.

Recentemente, ELDER ${ }^{50}$ relatou variantes homozigóticas das porfirias autossômicas dominantes (PAI, PV e $\mathrm{CPH}$ ) e, especificamente em relação à PAI, há relato de quatro crianças com padrão homozigótico, cujo quadro clínico, extremamente grave e com alta letalidade, não segue o padrão das crises típicas de PAI. Neste quadro genético peculiar, a atividade enzimática da URO-S é muito reduzida, variando de 1 a $17 \%$ do normal. A apresentação clínica destas crianças foi variável, indo desde retardo mental e agenesia do vermis cerebelar, até crises convulsivas febris e catarata bilateral, hipoplasia do nervo óptico, e óbito em uma delas, com a idade de oito anos. O quadro de deterioração neurológica é progressivo nestes casos.

\subsection{Biossíntese do Heme e Alterações Metabólicas}

As porfirinas são compostos fundamentais para a manutenção da 
vida, pois na biosfera são coadjuvantes nos processos de captação e utilização da energia ${ }^{128}$. Provavelmente as porfirinas, e especialmente o uroporfirinogênio, foram a fonte dos primeiros pigmentos necessários para a síntese da clorofila. Existem estudos que demonstram que a formação de porfirinas ocorreu quando da descarga elétrica em uma solução de metano, amônia e vapor d'água, e os catalisadores destas reações provavelmente teriam se desenvolvido precocemente na evolução da vida ${ }^{84}$. São grupos prostéticos responsáveis por todo o metabolismo oxidativo.

As porfirinas estão intimamente relacionadas com a biossíntese de heme, também chamado de ferroprotoporfirina. Este é definido como uma molécula plana, que exerce várias funções, conforme a apoproteína a que se associa, gerando hemoglobina, mioglobina, citocromos, peroxidases, e outras proteínas. Os citocromos estão envolvidos na cadeia mitocondrial de transporte de elétrons, da qual a fosforilação oxidativa depende. As enzimas que contém heme catalizam a liberação "quantizada" de energia que é usada para a formação de adenosina trifosfato (ATP).

Todas as células produzem heme, embora os principais produtores sejam o fígado e a medula óssea. A quantidade de heme no organismo depende inteiramente da produção endógena, pois o heme ingerido é completamente decomposto durante o processo digestivo. O catabolismo do heme e das hemoproteínas não produz porfirinas, mas sim compostos tetrapirrólicos com as características de pigmentos da bile, como a bilirrubina $^{123}$.

Cada porfiria é definida pela deficiência de determinada enzima da via 
de síntese do heme. Quando há interrupção completa deste mecanismo bioquímico, ocorre morte celular, enquanto que um distúrbio parcial do mesmo leva a acúmulos anormais de porfirinas, e a manifestações clínicas. Existem duas alterações enzimáticas principais responsáveis pelas modificações bioquímicas encontradas na PAl: a redução da atividade da URO-S e a indução da ALA-S. As enzimas da via de síntese do heme estão compartimentalizadas no interior da célula, ocorrendo as etapas iniciais e finais no interior da mitocôndria, e as demais no citoplasma celular (Figura 1). Esta via biossintética compreende oito etapas enzimáticas principais: 


\section{BIOSSÍNTESE DO HEME}

ENZIMA

PORFIRIA

ALA-sintetase

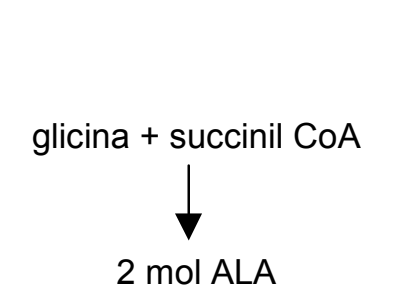

2 mol ALA

ALA-dehidratase

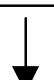

D-ALA-D

uroporfirinogênio-l-sintetase
(ou PBG deaminase)

uroporfirinogênio-I-sintetase
(ou PBG deaminase)

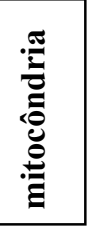

4 mol PBG

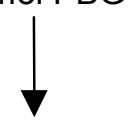

PAI

hidroximetilbilane

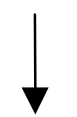

uroporfirinogênio I

uroporfirinogênio-III co-sintetase

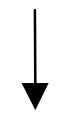

PEC

uroporfirinogênio III

uroporfirinogênio decarboxilase

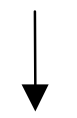

PCT

coproporfirinogênio III

coproporfirinogênio oxidase

protoporfirinogênio oxidase

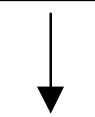

protoporfirinogênio IX

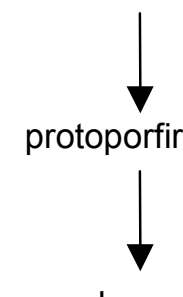

$\mathrm{CPH}$

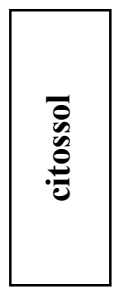

을

ferroquelatase

heme

Figura 1- Via biossintética do heme, com as enzimas deficitárias e seus respectivos tipos de porfiria. Algumas de suas etapas, como as reações de oxidação e redução, ocorrem na mitocôndria, e outras, no citoplasma, como a descarboxilação. Modificado de Schreiber, W.E.: A molecular view of the neurologic porphyrias. Clin. Lab. Med. v. 17, p.75, 1997 
Os cinco primeiros passos são condensações de pequenas moléculas, resultando na produção de uma estrutura em anel, o uroporfirinogênio III. A segunda metade do processo é responsável por modificações na estrutura do anel, oxidando-o, produzindo porfirina, e inserindo ferro na molécula.

A biossíntese do heme envolve, primeiramente, a condensação da succinil coenzima A com glicina, ativada com piridoxal fosfato. $\mathrm{O}$ produto desta reação é o ácido alfa-amino-beta-cetoadípico, rapidamente descarboxilado para formar ácido- $\delta$-aminolevulínico (ALA), o qual é o precursor alifático das porfirinas. Esta reação é catalisada pela ALAsintetase, localizada na mitocôndria.

A segunda fase da produção de heme ocorre quando o ALA difundese para fora da mitocôndria e forma PBG, o qual é um monopirrol precursor das porfirinas, através de auto-condensação, reação esta catalisada pela ALA-dehidratase. A URO-S é responsável pela condensação de quatro moléculas de PBG para formação de hidroximetilbilane, que espontaneamente assume uma forma cíclica, resultando na produção do tetrapirrol uroporfirinogênio I. Na presença da enzima uroporfirinogênio-III co-sintetase ocorre a formação de uroporfirinogênio III.

Os intermediários entre PBG e protoporfirina são formas reduzidas de porfirinas: os porfirinogênios, que são compostos incolores, em contraste com as porfirinas. Os porfirinogênios são rapidamente oxidados, formando porfirinas, através de agentes oxidantes como a luz. A auto-oxidação do uroporfirinogênio é ativada pelo produto, que é a uroporfirina. Portanto, a 
URO e a COPRO são meramente os subprodutos oxidativos dos seus respectivos porfirinogênios, os quais são os substratos da via biossintética. A conversão do coproporfirinogênio III a protoporfirina ocorre no interior da mitocôndria, através da enzima coproporfirinogênio oxidase, que necessita de oxigênio para sua ação. A função da enzima ferroquelatase é inserir íon ferro na protoporfirina, para a formação de heme.

Uma das propriedades do porfirinogênio é a de ligar-se a metais, mais comumente ferro e magnésio, atuando como quelante ${ }^{71}$. O anel tetrapirrólico das porfirinas é quelado com ferro, produzindo heme. A porfirina quelada com magnésio forma a clorofila. Quando o ferro é quelado por certas porfirinas, a sua capacidade de catalizar a decomposição do peróxido de hidrogênio $\left(\mathrm{H}_{2} \mathrm{O}_{2}\right)$ aumenta 10 vezes $^{71}$. As porfirinas e as hemoproteínas são um meio de utilização do ferro para várias funções bioquímicas: 1) transporte de $\mathrm{O}_{2}$ molecular (hemoglobinas); 2) transporte de elétrons (citocromos mitocondriais); 3) ativação do $\mathrm{O}_{2}$ (citocromo oxidase, triptofano pirrolase); 4) ativação de $\mathrm{H}_{2} \mathrm{O}_{2}$ (peroxidases); 5) decomposição de $\mathrm{H}_{2} \mathrm{O}_{2}$ (catalases) ${ }^{70}$.

A enzima limitante desta via no fígado é a ALA-S, cujo controle é efetuado por retro-alimentação negativa. Está sujeita tanto a mecanismos de repressão da atividade quanto de inibição da produção pelo heme. Existe uma pequena quantidade de heme intracelular livre que é reguladora do ritmo de expressão da ALA-S, e quando os níveis de heme caem, sua atividade aumenta. Conseqüentemente, uma redução na produção do heme leva a maior afluxo de substrato na via sintetizadora. A quantidade deste "pool" de heme regulador encontra-se normalmente em equilíbrio com vários 
outros reservatórios nos quais o heme é utilizado, como as hemoproteínas, das quais o citocromo $P_{450}$ é a principal, sendo também responsável pelo metabolismo oxidativo de algumas drogas, mais freqüentemente as lipossolúveis ${ }^{136}$.

O bloqueio enzimático apenas parcial não interrompe a produção do heme, porém estimula a atividade da ALA-S, causando acúmulo de substratos nos tecidos, que são excretados na urina. O controle secundário da via é exercido pela URO-S, também chamada de hidroximetilbilanesintetase ou porfobilinogênio-deaminase, que no entanto tem atividade relativamente pequena, e é inibida pelo protoporfirinogênio e coproporfirinogênio. Em alguns tipos de porfiria experimental, e nas porfirias hepáticas no ser humano, é a ALA-sintetase que se encontra aumentada no tecido hepático. Este aumento explica alguns dos achados bioquímicos nestas doenças. Nas porfirias agudas (PAI, PV, CPH, D-ALA-D) caracteristicamente há excesso de produção e redução do consumo de todos os precursores das porfirinas formados previamente ao defeito enzimático $^{67}$, com episódios agudos de manifestações neurológicas, enquanto que nas não agudas, com fotossensibilidade (PCT, PEC, PPE), ocorre somente a produção excessiva de porfirinas, mas não dos precursores destas, provavelmente por efeito compensatório da atividade da URO-S, somado também ao aumento da ALA-S.

Há descrições de concomitância de dois tipos de porfiria num mesmo paciente: em relação à PAI, este fato foi observado com a PCT e a PV. Neste último caso, esta porfiria é chamada de Chester, na qual ocorre 
simultaneamente deficiência das enzimas URO-S e protoporfirinogêniooxidase $^{150}$

A enzima URO-S encontra-se reduzida em aproximadamente $50 \%$ do normal em todos os tecidos de pacientes com PAI. Apesar disso, é apenas no fígado que a ALA-S encontra-se muito elevada, observando-se que em animais a indução desta enzima por várias substâncias encontra-se restrita ao tecido hepático, sendo a exceção a indução desta enzima pelos esteróides $5 \beta-\mathrm{H}$ nos eritrócitos ${ }^{189}$. Experimentalmente, observa-se que vários metais e hidrocarbonetos halogenados provocam alterações na síntese do heme. Demonstrou-se que a atividade da ALA-S pode ser estimulada por uma variedade de drogas, em animais, e que este estímulo pode ser bloqueado pela ingestão de carboidratos. O nível desta enzima pode encontrar-se aumentado até 50 vezes ou mais o valor normal.

O núcleo tetrapirrólico das porfirinas é aromático e hidrofóbico, e a solubilidade em água aumenta com o aumento de substituintes hidroxil ou carboxil. Assim, observa-se que a solubilidade hídrica é progressivamente maior na proto, copro, e uroporfirina ${ }^{187}$. Fisiologicamente, esta capacidade solúvel está em relação direta com a via de excreção ${ }^{155,165}$ de cada uma destas porfirinas: a protoporfirina, dicarboxílica, é excretada somente pela bile, a coproporfirina, tetracarboxílica, principalmente pela bile, porém também pela urina, como coproporfirinogênio, e a uroporfirina, octacarboxílica, predominantemente pela urina. O espectro de absorção é importante para identificar as porfirinas, e tem relação com certos comprimentos de onda específicos nos quais a fotossensibilização ocorre 
nas porfirias. Na PAl, observa-se excreção urinária aumentada apenas dos precursores das porfirinas ALA e PBG, e não das porfirinas URO e COPRO, que encontram-se em níveis normais na urina e fezes. Por este motivo, pacientes com PAI não apresentam fotossensibilidade, em contraste com outras formas de porfiria ${ }^{123}$. A excreção urinária destes precursores é conseqüência tanto da produção hepática aumentada, como da diminuição de sua utilização. Postula-se que o encontro ocasional de níveis elevados de uroporfirina nesta doença seja meramente um artefato que não representa a porfirina produzida enzimaticamente, pois sabe-se que o PBG pode ser polimerizado in vitro, especialmente num meio ácido, para formar porfirinas e outros pigmentos $^{187}$.

Algumas modificações bioquímicas são observadas nas porfirinas e seus precursores em função do meio em que se encontram. Há formação de polipirróis a partir de PBG quando da exposição da urina à luz, e as porfirinas obtém uma coloração vermelha ou marrom em soluções alcalinas ou em solventes orgânicos, e vermelho-púrpura em soluções ácidas. Quando presentes na urina em grandes quantidades, as porfirinas podem imprimir-lhe um tom de vermelho semelhante ao do vinho do porto.

\subsection{FATORES PRECIPITANTES}

São aqueles que podem converter a doença latente em manifestações clínicas. Embora o defeito fundamental, causador da doença, que é a redução em torno de $50 \%$ nos níveis de URO-S, esteja presente 
durante a vida inteira do paciente, as manifestações neurológicas só ocorrem ocasionalmente, e muitas vezes nunca ocorrem. Conclui-se, então, que este defeito enzimático é necessário, porém não suficiente, para que a doença se manifeste clinicamente, já que a produção fisiológica de heme não se altera se não houver uma demanda maior, como na presença de fatores que induzam o citocromo $\mathrm{P}_{450}$. Em todas as formas herdadas de porfiria humana, os fatores ambientais e metabólicos têm importância vital na determinação da expressão clínica da anormalidade genética. Fatores exógenos, como medicações e substâncias químicas, e endógenos, como hormônios, são necessários para que o defeito genético transpareça, o que inclui as porfirias agudas no rol das chamadas "doenças tóxico-genéticas"130. A maioria destes fatores parece agir através da indução da enzima ALA-S, cuja intensidade em resposta aos agentes indutores é diferente entre os indivíduos. Com base no conhecimento do papel regulador, exercido através de retro-alimentação negativa - explicitado anteriormente - que a enzima ALA-S exerce sobre a biossíntese do heme, e sabendo-se que a enzima ALA-S pode ser induzida no tecido hepático por diversas substâncias, como esteróides endógenos e exógenos, como demonstraram os trabalhos de GRANICK e URATA ${ }^{72}$, e que DE MATTEIS e MARKS ${ }^{40}$, mais recentemente, demonstraram experimentalmente em roedores e em células de fígado de embriões de galinhas, que alguns compostos porfirinogênicos, como barbitúricos, também induzem a hemoproteína microssomal do citocromo $\mathrm{P}_{450}$ como parte da resposta adaptativa do fígado à administração de drogas, postulou-se um mecanismo pelo qual algumas drogas precipitariam um 
ataque de PAl: em condições fisiológicas, existe enzima URO-S em quantidade suficiente para que ocorra a síntese de heme normalmente ${ }^{205}$. 0 bloqueio parcial na síntese do heme - produzido experimentalmente através de compostos químicos, como 3,5-dietoxicarbonil-1,4-dihidrocolina (DDC); alil isopropilacetamida $(\mathrm{AIA})^{118}$, e drogas ${ }^{40,114}$ - limitaria a resposta do fígado porfírico a aumentos repentinos na demanda para que houvesse aumento na síntese do heme, o que levaria à depleção hepática de heme, resultando na indução da ALA-S. Quando uma droga ativa o citocromo $\mathrm{P}_{450}$, ocorre maior incorporação de heme no citocromo $\mathrm{P}_{450}$ e uma redução no "pool" regulador de heme livre. Isto, por sua vez, leva a uma maior produção de ALAsintetase. A URO-S torna-se, então, o fator limitante na síntese de heme, havendo um rápido acúmulo de substratos precursores ALA e PBG. Como não são metabolizados, estes compostos saem dos hepatócitos, entram em outros tecidos, e são excretados pela urina.

Em tese, praticamente todas as drogas que induzem o citocromo hepático microssomal $\mathrm{P}_{450}$ podem causar ataques de porfiria. Embora a maioria das drogas incriminadas na gênese dos ataques sejam lipofílicas e indutoras da função oxidativa do sistema hepático, nem todas possuem estas características, sendo impossível prever com certeza, somente a partir da análise de sua estrutura química, se uma determinada droga é ou não segura para uso no paciente porfírico ${ }^{130}$. É provável que algum outro mecanismo também encontre-se envolvido no desencadeamento de crises através das drogas. TISHLER ${ }^{184}$ demonstrou, através de experimentos in vivo e in vitro, que as drogas conhecidas como precipitantes de ataques de 
porfiria não o são por ação direta sobre a atividade enzimática da URO-S. Este efeito foi encontrado somente com o uso de imipramina e etinilestradiol, embora tenha sido de leve intensidade e aparentemente sem conseqüência biológica.

Deve-se ressaltar que a identificação de substâncias que podem ou não desencadear uma crise de PAl é feita experimentalmente, e que, desta forma, não havendo um modelo ideal e padrão de porfiria experimental, podem existir falsos positivos e falsos negativos, dependendo do sistema utilizado. Não se sabe ao certo se todas as drogas que causam crises de PAl em porfiria induzida experimentalmente realmente desencadeariam um ataque ou, pelo menos, piora do quadro clínico, em seres humanos. Apresentaremos os principais grupos de fatores precipitantes das crises de PAl:

\subsubsection{Medicamentos e OUtRas Substâncias Químicas}

Os efeitos indutores das drogas geralmente são dose-dependentes. As drogas podem causar quatro tipos de efeitos em relação à PAl: precipitantes ou exacerbadoras da crise em humanos, causadoras de PAI em sistemas experimentais, seguras e provavelmente seguras, e suspeitas, com porfirinogenicidade ainda não confirmada (ANEXO A).

Desconhece-se o risco relativo de cada uma dessas drogas, mas certamente há consenso sobre o fato de que barbitúricos, griseofulvina e sulfonamidas devem ser evitados, já que existem abundantes relatos na literatura a respeito de ataques precipitados por estas medicações. As 
substâncias mais freqüentemente incriminadas são os barbitúrbicos, estrógenos, etanol, hidantoína, griseofulvina, meprobamato, anticoncepcionais orais e sulfonamidas. Todas as drogas dos dois primeiros grupos acima descritos também devem ser proscritas, e, de modo geral, devem ser adotados critérios extremamente cautelosos quando da prescrição de medicações a estes pacientes.

O etanol é uma substância reconhecidamente implicada no desencadeamento das crises de $\mathrm{PAI}^{131}$. A associação entre a ingestão de etanol e alterações no metabolismo das porfirias foi observada primeiramente em 1935 em um paciente que duplicou sua excreção de coproporfirina urinária após beber um litro de cerveja ${ }^{59}$. O etanol altera a atividade de uma série de enzimas participantes da síntese do heme: inibe a ALA-D e a ferroquelatase, e aumenta a atividade da ALA-S no fígado ${ }^{131}$.

Descreveu-se também tabagismo como fator responsável pela maior recorrência das crises de $\mathrm{PAI}^{106,130}$, provavelmente pelo fato de alguns dos componentes do cigarro interferirem com o metabolismo dos esteróides, e por induzirem o citocromo hepático $\mathrm{P}_{450}$.

Além do uso de determinadas medicações e do consumo excessivo de etanol, o contato com algumas substâncias químicas também deve ser evitado pelos pacientes porfíricos, pois PETERS ${ }^{144}$, em uma série de casos de PAl, estimou que metade deles havia sido precipitada pela manipulação de tintas a óleo ou solventes. Em humanos, também notou-se uma associação entre a exposição, prolongada e em níveis consideráveis, ao fungicida hexaclorobenzeno, e desenvolvimento de porfiria variegada e 
cutânea tarda ${ }^{37,145}$.

\subsubsection{JEJUM}

A demonstração de que a incidência de porfiria experimental ${ }^{159}$ e a excreção de precursores das porfirinas em pacientes com $\mathrm{PAI}^{55,203}$ variava em relação inversa com o consumo de carboidratos e proteínas, levou à conclusão de que o jejum e o tipo de dieta poderiam ter efeito sobre a ocorrência de ataques de PAI.

Os mecanismos pelos quais o jejum e a hipoglicemia causam a precipitação das crises de PAI não estão esclarecidos. Porém, especula-se que este efeito seja derivado da redução no bloqueio que os carboidratos exercem sobre a indução hepática da $A L A-S^{190}$, provavelmente através do efeito repressor sobre a síntese do seu RNA mensageiro ${ }^{115}$, levando ao aumento da atividade desta enzima.

Existem inúmeros casos descritos em que dietas para perda de peso indubitavelmente tiveram relação com o início das crises, as quais foram rapidamente revertidas quando da suspensão da restrição alimentar ${ }^{95,} 174$. Adoçantes artificiais, como a sacarina, também podem estar implicados no desencadeamento de crises, pois além de serem derivados de sulfas, em geral encontram-se associados a outros fatores precipitantes, como o jejum e/ou a hipoglicemia decorrentes da ingestão exclusiva destes compostos, embora ainda não se tenha comprovação a este respeito. Relata-se também que um ataque de PAI pode ser atribuído à nutrição deficiente causada por verminoses severas ${ }^{144}$. 
A ocorrência concomitante de vários fatores, como condições hormonais e dieta, além do eventual uso de drogas, provavelmente é a condição mais favorável para que haja o desencadeamento da crise de PAI. Como exemplo, existe na literatura relato de uma paciente que fazia uso regularmente de Seconal ${ }^{\circledR}$, um barbitúrico, e nunca havia tido crises evidentes de PAI, o que ocorreu quando retomou seu uso após tê-lo suspendido por vários meses, assim como outros pacientes que fizeram uso de barbitúricos continuamente por muito tempo, sem que a doença latente tenha se manifestado ${ }^{47}$. FELSHER e REDEKER ${ }^{55}$ estudaram o comportamento clínico e da excreção dos precursores ALA e PBG em pacientes que haviam recebido griseofulvina e sido submetidos a modificações na sua dieta, e observaram que a administração de drogas porfirinogênicas associada a uma dieta com alta quantidade de carboidratos aumentava a excreção dos precursores, porém não levava o paciente a apresentar manifestações clínicas. Assim, estes autores sugeriram que uma dieta rica em carboidratos poderia proteger o indivíduo de crises de PAI quando do uso de griseofulvina. Estes autores concluíram também que provavelmente a velocidade em que ocorrem as mudanças na dieta seja o fator mais importante, pois observaram que uma redução abrupta na ingestão calórica proveniente de carboidratos aumentava os níveis de precursores na urina, enquanto que uma adaptação gradual, em pacientes com PAI, não elevava significativamente a excreção destas substâncias. 


\subsubsection{FATORES HORMONAIS}

Além das drogas e da dieta, fatores endógenos, como os hormônios, também exercem papel importante no desencadeamento de crises. Os esteróides estão implicados na precipitação de crises. A favor desta teoria estão as seguintes constatações: as manifestações clínicas e bioquímicas costumam ocorrer após a puberdade, e mesmo as drogas raras vezes são desencadeantes de crises em crianças com deficiência de URO-S; a doença predomina claramente no sexo feminino; existem mulheres nas quais os ataques recorrem regularmente de acordo com o ciclo menstrual, geralmente três dias antes do início da menstruação, mas às vezes próximo ao período da ovulação ${ }^{38,209}$; ocorre aumento ou surgimento dos sintomas em algumas pacientes durante a gestação ${ }^{209}$, e, por fim, a influência que estrógenos exógenos exercem sobre a precipitação de porfiria ou sobre o metabolismo

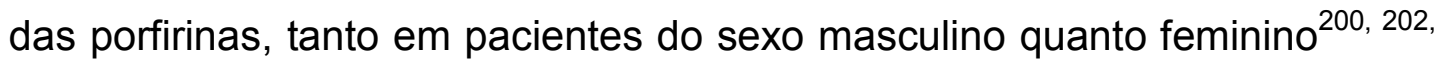
209. Corroborando esta tese, observou-se que os estrógenos podem produzir uma série de alterações bioquímicas semelhantes às encontradas na PAI, como alteração nos níveis da ALA-S. Mesmo em mulheres normais, há evidência de que ocorra um pico nos níveis leucocitários de ALA-S quando os níveis estrogênicos elevam-se ${ }^{180,188}$.

A maioria das pacientes do sexo feminino, no entanto, não sofre qualquer alteração quanto ao surgimento ou não de crises durante o período gestacional $^{163}$. Porém, em alguns casos, o abortamento está nitidamente relacionado com o fim da crise ${ }^{209}$. Observa-se também o inverso em 
algumas mulheres, ou seja, diminuição da freqüência dos ataques durante a gestação, os quais apresentavam-se mensalmente. $\mathrm{Na}$ maioria das mulheres também não há relação direta entre o período menstrual e a ocorrência de ataques, observando-se que apenas 10 a $20 \%$ das pacientes com PAI apresentam, em algum momento, ataques recorrentes aproximadamente três dias antes da menstruação, que duram cinco a seis dias, e cessam espontaneamente com o fim dela. Estes ataques podem ser semelhantes a quadros dismenorréicos, com dores abdominais, porém muitas vezes evoluem para quadros motores ${ }^{187,}{ }^{189}$. Paradoxalmente, a administração de estrógenos ou de anticoncepcionais orais em mulheres que apresentavam crises recorrentes mensalmente preveniu o surgimento destes ataques. Esta aparente contradição sobre o efeito do estrógeno na história natural das crises de PAI não pôde ainda ser explicada, porém é possível que os ataques cíclicos ligados ao período menstrual estejam relacionados com alterações do eixo hipotálamo-ovário, ou mesmo à responsividade tecidual a certos hormônios ${ }^{38}$.

Além dos estrógenos, os andrógenos e, principalmente, a progesterona, também podem estar implicados na precipitação das crises, pois os estrógenos são indutores relativamente fracos da ALA-S, especialmente quando comparados aos metabólitos dos andrógenos e à progesterona ou seus metabólitos. Além disso, as crises cíclicas observadas em mulheres são mais comuns na fase pré-menstrual, quando ocorre o pico de progesterona ${ }^{89}$ 
Na ausência de identificação de agentes precipitantes exógenos, atribui-se geralmente o desencadeamento das crises a fatores endógenos: hormônios gonadais e os produzidos pela supra-renal. O papel dos hormônios sexuais femininos no desencadeamento das crises ainda não está completamente esclarecido, porém, constatou-se que apenas os esteróides com configuração $5 \beta-\mathrm{H}$, entre os quais encontram-se os metabólitos da progesterona e da testosterona, são capazes de estimular a produção excessiva de porfirinas e a via de síntese do heme também nos eritrócitos in vitro, e que os de configuração $5 \alpha-\mathrm{H}$ seriam inativos ${ }^{189}$. A diferença estrutural entre estes compostos seria a posição cis do $H$ no carbono 5 em relação ao grupo metil no carbono 10, enquanto que no esteróide $5 \alpha-\mathrm{H}$ estaria em posição trans. Estudos mais recentes indicam que pode haver relação entre as substâncias produzidas nas adrenais, como a hidrocortisona, e alterações no metabolismo hepático das porfirinas.

\subsubsection{OUtRos}

Os processos infecciosos, bacterianos ou virais, também são reconhecidos como fatores precipitantes de ataques de PAI, embora o modo pelo qual isto ocorra também não esteja claramente explicado. Podem estar relacionados à anorexia e ao aumento na produção de esteróides $5 \beta-\mathrm{H}$ encontrados nestas ocasiões, ou mesmo ao uso de medicações contraindicadas a pacientes com PAl, como alguns antibióticos. Há relatos de crises nas quais os sintomas foram dor abdominal e neuropatia periférica, que ocorreram quando da presença de infecção das vias aéreas superiores, 
no período imediatamente anterior à menstruação, sugerindo que a interação de vários fatores pode ter sido decisiva para o desencadeamento da crise nestes casos $^{47,174}$.

Existe ainda um grupo de pacientes nos quais nenhum fator desencadeante, endógeno ou exógeno, pôde ser identificado.

\subsection{QuAdRo CLínico}

WALDENSTRÖM ${ }^{194}$, GARCIN e LAPRESLE ${ }^{63}$, GOLDBERG ${ }^{66}$, HIERONS $^{81}$ e RIDLEY ${ }^{153}$ foram os primeiros autores a descreverem detalhadamente, realçando aspectos importantes, o quadro neurológico da PAI. Quatro tipos de porfiria hepática apresentam-se clinicamente através de manifestações neurológicas semelhantes: porfiria aguda intermitente, porfiria por deficiência de delta-aminolevulinato dehidratase, coproporfiria hereditária, e porfiria variegata, sendo estas últimas duas acompanhadas também por manifestações cutâneas. O quadro clínico consiste em alterações neurovegetativas, neuropatia periférica sensitivo-motora, manifestações do sistema nervoso central ${ }^{90,124}$, psiquiátricas, e sistêmicas.

As lesões e as alterações funcionais podem ocorrer em qualquer área do sistema nervoso ${ }^{10,65}$, tanto periférico quanto central, embora algumas sejam afetadas mais freqüentemente que outras. Apesar de todas as manifestações encontradas no quadro clínico de uma crise serem de origem neurológica, nem sempre elas são aparentemente pertencentes a esta esfera, podendo o paciente às vezes ser primeiramente encaminhado a um 
clínico geral, cirurgião ou psiquiatra. Classicamente, a tríade dor abdominal, manifestações neurológicas e quadro psiquiátrico remete ao diagnóstico de PAI. Estas manifestações clínicas podem apresentar-se sob a forma de várias síndromes, em diversas combinações possíveis, e graus de intensidade variáveis.

\subsubsection{Manifestações Neurovegetativas}

\subsubsection{GASTRO-INTESTINAIS}

A sintomatologia abdominal é a manifestação inicial em $85 \%$ dos ataques de porfiria, não apenas inaugurando o quadro, mas também nas crises subseqüentes, sendo excepcional que um paciente manifeste outros sintomas como apresentação da doença ${ }^{63}$. Integram este quadro as dores e as alterações do ritmo intestinal. As dores abdominais habitualmente são intensas, geralmente em cólica, porém podem ser em pontadas ou ainda como cãimbras, sem sinais de peritonismo ao exame. Muito mais raramente têm intensidade menor, sendo então relatadas apenas como vago desconforto na região abdominal. Sua localização é variável, podendo ser difusas, no epigástrio, ou mesmo na região lombar, sugerindo cólicas renais, porém geralmente localizam-se nos quadrantes inferiores do abdomem ou no hipogástrio. A irradiação das mesmas pode atingir a região genital, e eventualmente ocorre migração da dor para outras localizações, inclusive durante o mesmo episódio de porfiria ${ }^{99}$. A dor abdominal pode estar ausente em alguns pacientes durante a crise de PAI, embora estes casos sejam raros. A duração da sintomatologia álgica varia de apenas algumas horas a 
vários dias, podendo ocorrer episódios únicos ou em número extremamente variável.

É freqüente a associação de quadro doloroso e alteração de ritmo intestinal, na maioria dos casos manifestando-se por obstipação, às vezes com duração superior a 15 dias, e mais raramente por diarréia. Náusea, acompanhada ou não de vômitos, é outro sintoma extremamente freqüente.

Ao exame clínico o abdome pode estar discretamente tenso, embora geralmente encontre-se flácido, sem dor localizada à palpação e sem sinais de irritação peritoneal, e à inspeção observa-se que o paciente adota uma posição encolhida como sendo a mais confortável. Os ruídos hidro-aéreos estarão diminuídos ou ausentes, quando a obstipação estiver presente, ou aumentado, quando o trânsito intestinal estiver acelerado.

A radiografia simples de abdome pode evidenciar áreas de espasmo e de dilatação das alças intestinais ${ }^{181}$, sugerindo a presença de obstrução intestinal mecânica. Freqüentemente estes pacientes são desnecessariamente submetidos a laparotomias exploratórias, eventualidade em que pode ocorrer agravamento dos sintomas, pela administração de anestésicos e outras drogas, e mesmo pelo estresse cirúrgico. Se o paciente já tiver sido submetido a várias intervenções cirúrgicas, pode haver maior sensibilidade abdominal devido à presença de aderências, o mesmo ocorrendo se houver obstipação por períodos muitos prolongados.

Muitos doentes apresentam quadros recorrentes muito freqüentes, de evolução crônica, entre as crises mais bem definidas, de desconforto abdominal inespecífico, de menor intensidade, associado a alteração da cor 
da urina, obstipação e labilidade emocional, muitas vezes recebendo indevidamente o diagnóstico de pacientes hipocondríacos, ou deprimidos.

\subsubsection{CARDIOVASCULARES E RESPIRATÓRIAS}

Nos quadros severos de PAI comumente são encontrados sinais de hiperatividade simpática ${ }^{89}$, como hipertensão arterial sistêmica, geralmente leve a moderada; sudorese excessiva; taquicardia, cujo valor em geral encontra-se entre 100 e 160 batimentos por minuto; e taquipnéia ${ }^{66}$. Estes quadros disautonômicos acarretam maior risco para os doentes, pois são potencialmente causa de arritmias cardíacas fatais, como fibrilação ventricular, e morte súbita ${ }^{20}$

A hiperventilação deve ser diferenciada da falência respiratória, e foi ocasionalmente descrita em associação à presença de alucinações, e em casos graves de porfiria, com distúrbios dos centros respiratórios do sistema nervoso central ${ }^{146}$. É também relatada hipotensão postural nestes pacientes, caracterizada como queda na pressão arterial sistólica maior do que 25 mmHg após mudança da posição supina para a ortostática, embora esta manifestação seja observada muito mais raramente ${ }^{174,181}$.

Os testes realizados por BLOM et al ${ }^{20}$ sugerem que a disfunção autonômica esteja associada com o traço genético e com as alterações bioquímicas, e não necessariamente com a expressão clínica da doença, já que as alterações cardiovasculares foram encontradas também em indivíduos com a forma latente da PAI. 


\subsubsection{DISTÚRBIOS ESFINCTERIANOS}

Bexiga neurogênica pode estar presente, em geral associada à neuropatia motora ou sensitivo-motora. A disfunção da motilidade vesical pode resultar em retenção, urgência, disúria ou incontinência urinária. Destas, a manifestação mais comum é a incontinência urinária.

Eventualmente, o distúrbio miccional pode se manifestar como hesitação ou retenção urinária intermitente, algumas vezes precedendo em algumas semanas o déficit motor nos membros.

Mais raramente observa-se disfunção também do esfíncter anal ${ }^{154}$.

\subsubsection{Manifestações do Sistema Nervoso PerifÉrico}

Em aproximadamente metade das crises de PAI a neuropatia periférica motora ou sensitivo-motora está presente $66,128,174,195$. É na maioria dos casos fundamentalmente motora, e a distribuição do quadro deficitário é variável de um paciente para outro, e até no mesmo paciente, de acordo com o estágio evolutivo em que ele se encontra. Pode eventualmente comprometer qualquer nervo periférico, na forma de mononeurite isolada ou múltipla, assimetricamente, ou, mais freqüentemente, acometer os quatro membros, embora a assimetria na instalação do quadro parético seja característica, ocorrendo a sucessão de eventos neuropáticos de maneira aparentemente aleatória, e, durante a progressão, finalmente assumir um caráter relativamente simétrico, como uma polineuropatia. O déficit habitualmente predomina nos membros superiores, onde é mais comum a 
instalação inicial do quadro parético, começando e permanecendo mais intenso na musculatura proximal, estendendo-se centrifugamente na maioria dos casos. Não é excepcional o acometimento do nervo radial isoladamente, completo ou parcelar, de maneira semelhante ao que ocorre na intoxicação pelo chumbo. Classicamente, há preferência pelos nervos extensores das mãos e dos pés ${ }^{63}$. Há também relatos isolados de neurite braquial e mononeurite de fibular, após compressão pelo ato de cruzar as pernas ${ }^{144}$.

O quadro motor pode eventualmente assumir um caráter semelhante ao observado na Síndrome de Landry-Guillain-Barré-Strohl, com progressão ascendente, podendo ser simétrica ou não. Ao contrário do descrito por vários autores, esta evolução ascendente não é um caráter de progressão muito freqüente na porfiria, sendo considerado por WALDENSTRÖM 195 "um exemplo interessante de como certos clichês científicos podem ser passados de um autor para outro", não tendo este autor observado nenhum caso deste tipo em 100 pacientes por ele analisados. É tipicamente uma neuropatia aguda, porém, a velocidade de progressão do quadro deficitário pode ser extremamente variável, de 72 horas a até meses, embora mais comumente dentro de alguns dias do início do quadro já esteja estabelecido o ápice do déficit motor ${ }^{154}$.

A musculatura torácica e a abdominal encontram-se afetadas menos freqüentemente que a dos membros, e quase sempre aparecem associadas a esta, não havendo aparentemente nenhuma sucessão bem definida entre os locais acometidos, como bem demonstrou WALDENSTRÖM ${ }^{193}$ em alguns de seus pacientes, que apresentaram déficits motores em locais distantes 
topograficamente, como por exemplo membros superiores, musculatura distal dos membros inferiores, músculos intercostais e diafragma, musculatura das coxas, nervo facial e vago, nesta ordem, ou membro superior esquerdo, nervo hipoglosso, musculatura distal dos demais membros, e tronco.

Os reflexos miotáticos profundos encontram-se hipoativos ou mesmo abolidos, se o acometimento for severo, mas podem ser normais em fases precoces $^{153}$. Uma particularidade refere-se ao fato dos reflexos aquileus ocasionalmente encontrarem-se preservados face às alterações nos demais territórios, principalmente em fases iniciais, o que poderia ser explicado pela maior intensidade do acometimento proximal. É freqüente o desenvolvimento de atrofia da musculatura, mesmo em fases precoces, de predomínio distal e nos membros superiores. Quando severo, o acometimento motor periférico pode levar ao aparecimento de fasciculações, embora estas sejam relativamente raras.

Observam-se manifestações sensitivas com freqüência relativamente alta, embora o quadro motor quase sempre predomine. Hipoestesia e parestesias, difusas ou localizadas, num padrão de distribuição do tipo bota e luva, ou de acometimento proximal, eventualmente atingindo a área perineal, podem estar presentes. Sintomas como disestesias e dores, sem características específicas, e mais raramente até na forma de cãimbras, são comuns, geralmente de localização distal nos membros inferiores, ou difusas por todo o corpo. Dor lombar, semelhante a ciatalgia, pode estar presente isoladamente ou acompanhar os demais sintomas. Podem às vezes 
apresentar-se como um quadro de dor crônica, porém geralmente integram as fases iniciais da crise porfírica, precedendo o envolvimento motor. É pouco freqüente o advento destes sintomas dolorosos sem que haja quadro deficitário associado. Desaparecem precocemente em relação à melhora do quadro parético. Ocasionalmente podem não existir sinais objetivos de comprometimento sensitivo, embora o paciente possa apresentar disestesias extremamente incômodas. A hipoestesia é habitualmente superficial, mas a sensibilidade profunda às vezes também é afetada ${ }^{8}$. Neste caso, a palestesia encontra-se alterada mais comumente que a $\operatorname{artrestesia}^{154}$.

O quadro de paresia decorrente de neuropatia periférica é quase sempre precedido por dor abdominal, e em 5 a $10 \%$ destes ataques, também por sintomas mentais ${ }^{153}$. Pode ocorrer dor abdominal sem que a neuropatia periférica manifeste-se, porém existem casos em que o intervalo entre o início das crises e o surgimento do primeiro ataque com neuropatia sensitivo-motora foi extremamente longo, variando de 3 meses a 14 anos $^{153}$. Em geral, este tempo é muito mais curto, entre 3 e 75 dias na série estudada por RIDLEY ${ }^{153}$. A neuropatia periférica geralmente progride de maneira contínua, até estabilizar-se, seguindo-se a recuperação dos déficits. No entanto, em menor número de casos, pode ser observada uma evolução "em degraus", com períodos de estabilização alternados com recrudescência dos déficits.

Os nervos cranianos também são acometidos em algumas ocasiões, encontrando-se quadros de paralisia facial com maior freqüência, assimétrica ou unilateral mais comumente, em geral em associação com 
déficits motores mais extensos ${ }^{10}$. Há também relatos de comprometimento dos nervos hipoglosso, acessório, vestibular, trigêmeo motor e sensitivo, e da motricidade ocular extrínseca e intrínseca, observando-se excepcionalmente anisocoria ${ }^{174}$. Raramente os nervos ópticos são afetados, causando redução da acuidade visual e mesmo amaurose, transitória ou definitiva, por atrofia do nervo óptico ${ }^{39,98,174}$.

A paralisia do nervo frênico e o envolvimento bulbar dão origem à insuficiência ventilatória, que é a causa mais comum de mortalidade entre estes doentes, e requer assistência respiratória imediata.

\subsubsection{Manifestações do Sistema Nervoso Central}

Os sinais de acometimento de algumas áreas do sistema nervoso central podem ser encobertos pela presença de neuropatia periférica. Talvez por isso, sugerem TADDEINI e WATSON ${ }^{181}$, raramente sejam observados sinais piramidais e extra-piramidais. Estes últimos geralmente são secundários à utilização de fenotiazínicos, mas podem também ser atribuídos ao envolvimento dos gânglios da base. Algumas vezes obtém-se sinal de Babinski e clônus de aquileu, mesmo na presença de envolvimento do sistema nervoso periférico (SNP) ${ }^{181}$, e, precocemente, os reflexos podem ser hiperativos ${ }^{174}$. Sinais de disfunção cerebelar também são observados em alguns pacientes ${ }^{66}$.

O nível de consciência pode alterar-se em quadros mais severos, manifestando-se em fases iniciais como lentificação psico-motora. Estados confusionais, com déficit de atenção, também são observados em alguns 
casos.

O padrão de sono também é ocasionalmente afetado nestes pacientes, tendo RIDLEY ${ }^{153}$ descrito insônia e pesadelos como sintomas iniciais de quatro entre cinco pacientes que iniciaram a crise com alterações mentais.

Eventualmente podem ocorrer crises convulsivas, generalizadas ou focais, embora este quadro seja relativamente raro $^{27}$. Mais freqüentemente, manifestam-se no início do quadro deficitário motor. Há descrições de episódios de amaurose cortical e, menos comumente, de agnosia visual ${ }^{98}$.

\subsubsection{MANIFESTAÇÕEs PSIQUIÁTRICAS}

A importância e a freqüência das manifestações da esfera psiquiátrica estão bem representadas pelo exemplo de que, enquanto a incidência de doentes de PAI na população da Inglaterra é de 5:100.000 indivíduos, na população psiquiátrica a prevalência é de $210: 100.000^{185}$.

O quadro psiquiátrico manifesta-se nestes pacientes através de comportamentos histéricos e alterações de personalidade ${ }^{36}$, erroneamente diagnosticados como funcionais, o que pode ter conseqüências dramáticas para a evolução destes casos. Em alguns pacientes, mesmo os sintomas precoces da neuropatia periférica chegaram a ser rotulados como histéricos. Outros sintomas psiquiátricos descritos são: delírio, semelhante ao delirium tremens, excitação catatônica, psicose paranóide, e menos freqüentemente, quadros depressivos. Além destes, observam-se também quadros de ansiedade, distúrbios do humor, como irritabilidade, alucinações visuais e 
auditivas, micro ou macropsia, sintomas estes que podem ser tão preocupantes para o paciente que podem focalizar totalmente sua atenção, levando-o a desinteressar-se do que ocorre ao seu redor, e a ser pouco colaborativo com o examinador. Conjuntamente, estes sintomas mentais são conhecidos como encefalopatia porfírica.

É ainda controverso se a porfiria pode estar causalmente relacionada a quadros psiquiátricos crônicos ${ }^{141}$, como depressão e esquizofrenia, não existindo porém evidências objetivas a este respeito.

\subsubsection{MANifestaÇões Sistêmicas}

Algumas crises de porfiria podem inaugurar-se com sintomas prodrômicos, como mal-estar indefinido, irritabilidade e dores vagas, poucos dias antes de manifestações mais incisivas estarem presentes, porém este quadro em geral só é valorizado quando avaliado retrospectivamente, dada a sua inespecificidade ${ }^{102}$.

Um dos aspectos mais característicos do ataque de PAl é a alteração da coloração da urina. GÜNTHER ${ }^{75}$ descreve a cor da urina de pacientes com PAl como "vinho tinto, porto, málaga, magenta, cor de cereja, e eventualmente quase negra". No entanto, existem pacientes nos quais a urina não sofre modificação de cor, e nos quais o diagnóstico é mais raramente firmado.

Ocasionalmente são observadas alterações hidroeletrolíticas durante o surto de PAI. A hiponatremia é a alteração laboratorial mais comumente encontrada nestes pacientes (18\%). FRÈRE et al. ${ }^{60}$ observaram que ela é 
mais freqüente nos pacientes com acometimento neurológico periférico. Em alguns pacientes, encontra-se associação de baixos níveis séricos de sódio com hipomagnesemia e hipocalcemia. Leucocitose é a segunda alteração laboratorial mais freqüente, com $17 \%$, seguida de anormalidades nas enzimas hepáticas (10\%). Em 10 a 40\% dos casos, leucocitose e febre acompanham a dor abdominal, mimetizando processos inflamatórios intraabdominais $^{49,66,174}$.

Segundo STEIN e TSCHUDY ${ }^{174}$, em quase todos os pacientes com PAl observou-se intolerância à glicose, particularmente durante as crises. Além disso, hipercolesterolemia foi encontrada em $40 \%$ dos pacientes, associada a aumento na concentração de $\beta$-lipoproteína ${ }^{189}$. Alterações no metabolismo hormonal, favorecendo a produção de metabólitos do esteróide $5 \beta-\mathrm{H}$, indutor de crises de porfiria, também foram observados. Outro aspecto descrito é a liberação inadequada de hormônio do crescimento em alguns pacientes, após sobrecarga de glicose ${ }^{143}$. Em alguns pacientes ocorre também elevação dos níveis de iodo ligado a proteína sérica ${ }^{181}$, porém a taxa metabólica basal e a captação de iodo 131 são normais, geralmente no limite inferior. SAINT e CURNOW ${ }^{163}$ descreveram anemia hemolítica em um paciente, durante o ataque, achado não corroborado por outros autores. Algumas pacientes podem apresentar galactorréia durante o surto.

A aparência da pele foi descrita como "metálica", ou com aumento da pigmentação em alguns casos, e hipertricose pode estar presente ${ }^{103}$. Durante uma crise, o chamado "brilho malar" pode ser visível na face, embora este sinal seja raramente observado. A associação da PAl com 
disfunção hepática, contrariamente às demais porfirias hepáticas (PV e $\mathrm{CPH}$ ), ainda é controversa.

Existem ainda formas atípicas de apresentação de porfiria aguda, com relatos isolados que necessitam de confirmação, como a de CHAUDHRY ${ }^{32}$, cuja paciente inaugurou a crise com pericardite, miocardite e sinais de irritação meníngea. Neste caso, porém, tratava-se de porfiria variegada, confirmada pelos exames laboratoriais. GARCIN e LAPRESLE $^{63}$ também $^{2}$ observaram esta reação meníngea em um de seus pacientes. COHEN et al. $^{33}$ descreveram um caso sem dor abdominal e com quadro doloroso muscular e fraqueza difusos, de caráter intermitente, acompanhado de febre e leucocitose, sem elevação da enzima creatino-quinase, nem alteração ao eletromiograma, porém a biópsia muscular evidenciava atrofia de fibras de causa neurogênica, e o diagnóstico de PAl foi confirmado através da dosagem da enzima deficitária. Este paciente apresentou também um episódio de amaurose monocular.

\subsubsection{Diagnóstico Diferencial}

Segundo WALDENSTRÖM ${ }^{194}$, uma grande variedade de diagnósticos incorretos pode ser feita num paciente com PAI, "que parecem ser muito bem fundamentados quando não se sabe nada sobre a porfiria aguda do paciente". Não existe um teste laboratorial que seja isoladamente suficiente para que se exclua o diagnóstico de PAI, e se existe esta suspeita, recomenda-se que sejam investigadas também a $\mathrm{PV}$ e a $\mathrm{CPH}$. Estas outras porfirias, assim como a D-ALA-D ${ }^{74}$, podem ter quadro clínico semelhante, 
pois são as que apresentam alterações neuropsiquiátricas mais proeminentes. Tomando-se isoladamente o quadro neurológico, pode-se afirmar que este é indistingüível entre estas porfirias, embora quadros severos de neuropatia geralmente sejam encontrados especificamente na $\mathrm{PAl}^{205}$. A D-ALA-D apresenta-se com sintomas idênticos aos da PAI, porém é extremamente rara, e seu padrão de transmissão é autossômico recessivo, podendo manifestar-se na infância. Nesta porfiria, há acúmulo apenas de ALA. O padrão de excreção de porfirinas na urina e nas fezes é útil na diferenciação do tipo de porfiria ${ }^{150}$ (ANEXO E). Porfirias fotossensíveis (PCT, PV, $\mathrm{CPH}, \mathrm{PPE}$ ) são na maioria das vezes facilmente distinguíveis pela presença de manifestações cutâneas, embora em alguns casos estas possam estar ausentes em fases iniciais.

O quadro neurológico periférico clinicamente mais semelhante à PAl é o da Síndrome de Landry-Guillain-Barré-Strohl, pelo modo de instalação, quadro doloroso, e pelas manifestações motoras e autonômicas ${ }^{24,56,120}$. RIDLEY ${ }^{154}$ sugere que a taquicardia nesta afecção raramente é tão importante quanto a observada na porfiria.

As porfirinúrias sintomáticas, destacando-se entre elas o plumbismo, devem ser consideradas como diagnósticos diferenciais. O quadro neurológico e os distúrbios de comportamento são semelhantes aos da PAI. A intoxicação por chumbo causa acúmulo de protoporfirina nos eritrócitos e aumento da excreção urinária de ALA e COPRO, tendo-se observado que as mulheres apresentam quadro de coproporfirinúria mais intenso que os homens. Nesta forma de porfirinúria não há fotossensibilidade, pois a 
protoporfirina quelada pelo zinco $(\mathrm{Zn})$ permanece retida nos eritrócitos. A inibição das enzimas ALA-D, coproporfirinogênio oxidase e ferroquelatase pelo $\mathrm{Pb}$ é o mecanismo pelo qual ocorre o acúmulo de porfirinas e seus precursores, levando a um aumento da enzima controladora da taxa de síntese, a ALA-S. O quadro clínico nesta doença, assim como em outras porfirinúrias, é atribuído não diretamente à anormalidade nas porfirinas, e sim à disfunção primária, manifestando-se por dor abdominal, neuropatia periférica crônica, obstipação, declínio intelectual, e anemia. Esta é causada pela hemólise e pelo efeito depressor do $\mathrm{Pb}$ na biossíntese de heme e de globina. Habitualmente, na intoxicação pelo $\mathrm{Pb}$ não é observado acometimento de nervos cranianos, do tronco, ou alterações esfincterianas. Os aspectos histopatológicos da PAI não são distinguíveis de várias outras afecções do sistema nervoso periférico, como por exemplo o da intoxicação por chumbo. De modo geral, os sintomas agudos que ocorrem quando a excreção urinária de PBG é normal não podem ser atribuídos à PAI.

A tirosinemia hereditária é causada por um erro inato do metabolismo, especificamente pela deficiência da enzima fumarilacetoacetato hidrolase, acarretando elevação nos níveis de succinilacetona e conseqüente inibição da ALA-D e excreção urinária excessiva de ALA. Embora laboratorialmente haja semelhança com as alterações observadas na PAI, clinicamente as duas entidades apresentam algumas diferenças, pois em metade destes pacientes há retardo mental, ataxia sensitiva e alterações da córnea, além de lesões cutâneas ${ }^{2}$. 
Quando as manifestações psiquiátricas são proeminentes, é importante o diagnóstico diferencial com esquizofrenia ${ }^{35,53}$. Em alguns pacientes psiquiátricos sem porfiria, observou-se excreção urinária excessiva de algumas substâncias semelhantes às porfirinas, e o hemopirrol lactama é excretado em excesso tanto em pacientes com PAl quanto em alguns pacientes esquizofrênicos ${ }^{129}$.

A intoxicação por tálio, e principalmente a por arsênico, também devem ser incluídas no diagnóstico diferencial, embora diferenciem-se em alguns dos sinais apresentados, como alopécia no primeiro e hemólise e irritação de mucosas no segundo. Apresentam-se clinicamente sob a forma de dores abdominais, náuseas e vômitos, seguidos por neuropatia periférica, além de quadros psiquiátricos, crises convulsivas e ocasionalmente rebaixamento do nível de consciência, evoluindo para coma em casos mais graves $^{2}$

O quadro laboratorial das hepatopatias, das Síndromes de Rotor, Dubin-Johnson, e da hiperbilirrubinemia da Síndrome de Gilbert, pode apresentar alguns aspectos que também são encontrados em algumas porfirias: aumento da excreção urinária de COPRO, e aumento da atividade da ALA-S nos leucócitos periféricos. Clinicamente, porém, são facilmente distingüíveis da PAl.

\subsubsection{EvoLução}

Os ataques de $\mathrm{PAl}$ geralmente têm progressão rápida, e a recuperação ocorre em dias ou às vezes em semanas, de modo PAULA MARZORATI KUNTZ PUGLIA 
imprevisível. A ocorrência de quadros fatais é estimada em $5 \%$ dos ataques que necessitam de hospitalização ${ }^{82}$. Esta porcentagem eleva-se quando o diagnóstico é tardio ou se o paciente é tratado inadvertidamente com drogas contra-indicadas. WALDENSTRÖM ${ }^{194}$, em 1939, observou que antes do uso mais difundido de medicamentos, os quadros mais graves ou mesmo fatais de PAI eram extremamente raros, como a descrição de RANKING e PARDINGTON $^{151}$ em 1890 de um caso fatal de porfiria, aparentemente sem fator exógeno precipitante. Desde então, progressos terapêuticos como ventilação a pressão positiva intermitente e antibióticos têm diminuído consideravelmente a mortalidade causada por esta doença, porém casos fatais ainda ocorrem. Mesmo os quadros graves são potencialmente reversíveis.

A persistência de sintomas cronicamente, como dor, depressão e ansiedade, pode ser de difícil avaliação, devendo-se considerar nesses casos a possibilidade de dependência de drogas. Porém, se houver excreção excessiva de ALA ou PBG durante este período, os sintomas devem ser a princípio atribuídos à continuidade da própria doença. Se o surto for suficientemente severo, ou se houver recorrência freqüente dos ataques, podem ocorrer lesões axonais e da bainha de mielina tão importantes, que a recuperação dos déficits torna-se prolongada, ou estes, permanentes. ADAMS et al. ${ }^{1}$ descreveram atrofia neurogênica do músculo secundária a lesões persistentes do nervo em pacientes com PAI. Os danos neurais na PAI podem, em sua maioria, ser comparados à axonotmese, ocorrendo restabelecimento completo da função do nervo quando de menor 
intensidade. No entanto, dependendo da intensidade da agressão, pode haver degeneração importante do axônio, e a recuperação do quadro tornase mais lenta, ou mesmo não ocorre. O déficit motor e as alterações sensitivas de localização mais distal tendem a recuperar-se em prazos maiores do que aqueles proximais, mesmo quando estes últimos são mais intensamente acometidos. Em média, a recuperação motora completa ocorre num prazo de 10 meses $^{137,153}$ nos músculos proximais com déficit mais acentuado, e quase o dobro na musculatura distal.

Outras possíveis seqüelas são insuficiência renal e hipertensão arterial sistêmica $^{82}$. Esta última foi evidenciada em aproximadamente $40 \%$ dos pacientes com PAI num acompanhamento a longo prazo ${ }^{12}$.

\subsubsection{DOENÇAS ASSOCIADAS}

LINET et al. ${ }^{105}$ avaliaram a possibilidade de pacientes com PAI desenvolverem câncer hepático e pulmonar, encontrando risco maior nestes pacientes do que na população controle, porém, menor que naqueles com PCT, mesmo levando-se em conta fatores de risco como hepatite por vírus C e tabagismo, respectivamente.

Eventualmente pode haver concomitância com cirrose, hemossiderose e síndrome de Gilbert $^{189}$, embora a função hepática na PAI em princípio não seja comprometida.

Disfunções endócrinas, como diabetes insipidus, galactorréia ${ }^{189}$, e hipertireoidismo também foram relatadas. 
Foram ainda descritas outras doenças concomitantes, embora não seja conclusivo se a associação é meramente coincidental ou não ${ }^{89}$, como no caso do lúpus eritematoso sistêmico e da pancreatite recidivante.

\subsection{ETIOPATOGENIA}

A maioria das manifestações clínicas observadas nas crises de PAI são de origem neurológica. Os mecanismos patogenéticos que causam estas alterações permanecem pouco conhecidos ${ }^{97,205}$, apesar dos recentes avanços em genética molecular e bioquímica das porfirinas. Isto deve-se à dificuldade de reprodução deste distúrbio em modelos animais. A porfiria produzida experimentalmente, através de drogas e outras substâncias, proporciona um modelo útil para a compreensão dos mecanismos de controle da síntese do heme, porém não para a elucidação daqueles que envolvem a patogênese da neuropatia periférica na PAI. O desenvolvimento de cobaias modificadas geneticamente, com níveis reduzidos de URO-S, permitiu a simulação dos distúrbios bioquímicos e das características patológicas da neuropatia periférica da PAl em humanos, porém não tornou possível o estudo adequado das manifestações do sistema nervoso central neste modelo ${ }^{104,124}$

Nenhum dos mecanismos propostos até o momento justifica de forma satisfatória os distúrbios encontrados nesta doença. No entanto, as evidências sugerem que ocorra interação de vários fatores, em seqüência ou paralelamente, causando as diversas manifestações clínicas, como por 
exemplo interação do ALA com receptores para o ácido gama-amino-butírico (GABA), alteração do metabolismo do triptofano, e depleção de heme nas células $^{124}$.

As alterações bioquímicas podem causar dois tipos de anormalidades: funcionais e estruturais. De modo geral, as primeiras seriam responsáveis por manifestações no sistema nervoso central, sendo rapidamente reversíveis quando da recuperação da homeostase metabólica; as alterações estruturais podem estar presentes, mas são relativamente escassas, e seriam observadas predominantemente no sistema nervoso periférico $^{205}$. Em relação aos distúrbios no sistema neurovegetativo, observam-se alterações a princípio funcionais, mas que podem tornar-se lesões estruturais, dependendo da intensidade do acometimento.

Existem, segundo YEUNG-LAIWAH et al. ${ }^{207}$, quatro hipóteses para explicar a patogênese da neuropatia na PAI. As duas mais prováveis são as que consideram a deficiência de heme e a ação do ALA sobre o sistema nervoso.

\subsubsection{DeficiênCla de Heme nos Tecidos Neurais}

As manifestações neuropáticas decorreriam da deficiência de heme nas células nervosas, o que aparentemente estabelece correlação satisfatória entre os achados clínicos, bioquímicos e neuropatológicos desta doença. Sabendo-se que o heme é fundamental para a constituição de enzimas respiratórias, responsáveis pelo transporte de oxigênio, de elétrons, 
e pelo sistema do citocromo $\mathrm{P}_{450}$, a deficiência de heme poderia restringir a capacidade do processo oxidativo mitocondrial nas células nervosas, levando à hipóxia celular e ao comprometimento da função nervosa.

O citocromo $\mathrm{P}_{450}$ é uma hemoproteína importante no metabolismo hepático oxidativo, e teoricamente sua função também estaria prejudicada quando da diminuição dos níveis de heme. A possibilidade de que a deficiência de outras proteínas derivadas do heme, como por exemplo a citocromo oxidase, possa contribuir para a etiopatogenia desta doença, também não está excluída. Este mecanismo causaria um bloqueio neuronal funcional, com redução na utilização tecidual de oxigênio ${ }^{207}$. O transporte mitocondrial de elétrons também é dependente de hemoproteínas, e a depleção destas teria como conseqüência um distúrbio na produção de ATP e provavelmente também no transporte axonal, causando degeneração axonal no SNP ${ }^{205}$. Porém, esta explicação não é totalmente satisfatória, pois o quadro clínico da PAI é diferente do observado nas doenças mitocondriais. É aventada a hipótese de que talvez a disfunção mitocondrial possa favorecer o dano causado pelos radicais livres (vide item 1.7.2).

Apesar de justificar de maneira satisfatória as manifestações clínicas no SNP, a deficiência de heme no SNC, causando alterações no mecanismo oxidativo celular, parece menos provável, pois neste sistema a produção neuronal de citocromo $\mathrm{P}_{450}$ e a ALA-S não são induzidas por drogas exógenas, como no tecido hepático ${ }^{207}$. No entanto, esta hipótese não pode ser totalmente excluída, pois é possível que algum distúrbio na função do citocromo $\mathrm{P}_{450}$ no tecido cerebral ou em outros locais do sistema nervoso 
altere o metabolismo de compostos neuroativos, que poderiam secundariamente afetar a função neurotransmissora.

BADAWY e EVANS $^{9}$ foram os primeiros autores a tentarem correlacionar as alterações da enzima triptofano pirrolase com o aumento da serotonina, e o efeito deste distúrbio bioquímico no surgimento dos sintomas psiquiátricos. A triptofano pirrolase é uma enzima importante no processo metabólico oxidativo, responsável pela transformação do triptofano em outra substância, a cinurenina. Quando há deficiência de heme, caem os níveis desta enzima, e, conseqüentemente, aumentam os do triptofano. Este é precursor da serotonina, que também encontra-se elevada na crise de PAI. Este neurotransmissor atua sobre vários receptores no sistema nervoso central, no periférico e no neurovegetativo.

\subsubsection{Neurotoxicidade Devido ao Acúmulo de Precursores DAS PORFIRINAS (ALA E PBG)}

Atualmente, considera-se que a hipótese mais provável é a que envolve o ALA e o PBG na etiopatogenia das manifestações clínicas da PAI. A observação de que o quadro neuropsiquiátrico ocorre somente nas porfirias hepáticas nas quais há aumento da excreção urinária de ALA e $\mathrm{PBG}^{21}$, e a constatação de que não ocorre manifestação clínica na PAl quando a excreção de precursores na urina encontra-se em níveis normais $^{15}$, teve como conseqüência o fato de tentar-se estabelecer conexão entre estes precursores e as manifestações patológicas do sistema nervoso, deduzindo-se que o ALA e o PBG estariam de alguma forma implicados na patogenia dos sintomas observados durante a crise. Estes precursores são 
detectados no líquido céfalo-raquidiano durante as crises de porfiria, enquanto que nas fases latentes e nos indivíduos normais eles estão ausentes $^{154}$. As hipóteses aqui descritas foram elaboradas em função de estudos em animais $\mathrm{e}$ in vitro, não sendo todavia comprovada sua transposição para os eventos que ocorrem nos pacientes com PAI, já que muitas vezes as concentrações de precursores necessárias para que as alterações ocorram são muito mais elevadas do que as observadas nos indivíduos com porfiria.

O maior obstáculo à atribuição das manifestações neurológicas ao excesso de ALA e PBG é o fato de não haver correlação entre o grau de acometimento e os níveis de precursores na urina, além de vários pacientes assintomáticos excretarem grandes quantidades destes ${ }^{207}$. KRAMER et al. ${ }^{97}$ contestam este fato através de vários exemplos de pacientes que claramente elevaram os níveis de precursores excretados na urina em momentos de franca progressão da doença, com piora do quadro neurológico, e evolução para óbito em alguns deles, sugerindo que a captação dos precursores pelo sistema nervoso ocorre quando suas concentrações encontram-se em níveis bastante elevados. Além disso, a concentração destes metabólitos no líquor não necessariamente é a mesma que a intracelular. Sabe-se que em alguns pacientes, embora haja melhora no padrão bioquímico, ocorre persistência do quadro clínico, devendo-se isto provavelmente à permanência prolongada do ALA no sistema nervoso central, onde sua metabolização é lenta, ou à presença de lesões neurológicas irreversíveis, sendo esta a explicação para a dissociação 
eventualmente encontrada entre o padrão de excreção de ALA e PBG e a gravidade das manifestações clínicas.

A barreira hemato-encefálica é permeável à passagem de PBG, como demonstraram SWEENEY et al. ${ }^{180}$ e BONKOVSKY et al. ${ }^{23}$. Uma hipótese postula que o PBG tenha ação mimética à da serotonina, agindo como um falso neurotransmissor. Este é um mecanismo considerado duvidoso, já que pacientes com D-ALA-D e tirosinemia hereditária, com aumento da produção de ALA, mas não de PBG, têm quadro neurológico semelhante ao da PAI ${ }^{154}$.

A administração intraventricular de ALA em cobaias produz efeitos neurotóxicos, como sonolência, ataxia e convulsões, provavelmente através da inibição da ATPase no tecido cerebral, embora as concentrações necessárias para que ocorra este efeito sejam relativamente altas $\left(10^{-4} \mathrm{M}\right)$, sendo pouco provável que este nível seja atingido durante uma crise porfírica (em geral a concentração é de $10^{-5}$ a $10^{-7} \mathrm{M}$ no líquido céfaloraquidiano). Em concentrações plasmáticas próximas às observadas nos surtos de porfiria, o ALA consegue transpor a barreira hemato-encefálica, e manter-se em níveis elevados no tecido cerebral mesmo após os níveis plasmáticos terem-se normalizado. No SNP a concentração de ALA está muito próxima da plasmática $\left(10^{-5} \mathrm{M}\right)$, já que não há barreira como a hematoencefálica.

Sabe-se que o ALA é incorporado às células numa via comum com o ácido gama-amino-butírico ${ }^{17}$, compartilhando a mesma permease responsável pelo seu transporte. O aumento nos níveis de ALA provocaria então um bloqueio na neurotransmissão fisiológica de GABA. Este precursor 
compete pelos receptores pré-sinápticos do GABA, interagindo com ao menos dois tipos destes receptores. Este efeito ocorre na presença de concentrações de ALA encontradas em crises de porfiria $\left(10^{-6} \mathrm{M}\right)^{26}$. Em concentrações um pouco maiores $\left(10^{-4} \mathrm{M}\right)$, há inibição da captação e aumento do efluxo não só de GABA, como de outro neurotransmissor, o glutamato, que é excitatório, e também semelhante ao ALA estruturalmente. Estudos in vitro demonstraram que o ALA seria capaz de ativar receptores para este neurotransmissor também nos neurônios sensitivos e motores do SNP.

O aumento nos níveis de triptofano, anteriormente explicitado, em condições fisiológicas eleva a concentração de melatonina, o que porém não ocorre na crise de PAI, onde, paradoxalmente, a sua secreção pela glândula pineal encontra-se reduzida. Supõe-se que esta redução paradoxal da melatonina seja devida a uma ação direta do ALA sobre a glândula pineal, já que a vascularização desta encontra-se fora da barreira hemato-encefálica. Isto ocorreria pela semelhança estrutural do ALA com o GABA, sendo este um inibidor da síntese e liberação da melatonina ${ }^{148}$.

O estresse oxidativo pode ser um fator importante, pois o ALA atua como agente oxidante no tecido cerebral de ratos ${ }^{41}$. Recentemente, dados de alguns estudos sugerem que o ALA possa ter importante papel na geração de radicais livres ${ }^{13},{ }^{14,34}$, candidatando este precursor das porfirinas a responsável pelas alterações neurológicas da PAI e de outras afecções decorrentes de defeitos na via biossintética do heme. O nível de estresse oxidativo pode ser constatado através de parâmetros como aumento da 
atividade de enzimas anti-oxidantes, aumento da captação de $\mathrm{Ca}^{++}$, e sinais de danos a estruturas lipídicas e proteicas celulares ${ }^{124}$. MEDEIROS et al. ${ }^{121}$ demonstraram que em pacientes com PAl ou com intoxicação por $\mathrm{Pb}$ os níveis eritrocitários de enzimas anti-oxidantes, como a superóxido-dismutase - somente durante a crise - e glutatione peroxidase - tanto nos pacientes sintomáticos quanto nos portadores - encontram-se elevados. Analogamente, foi observado em trabalhadores expostos ao chumbo uma relação linear entre os níveis plasmáticos deste metal e de ALA, e entre os de chumbo e de enzima superóxido-dismutase ${ }^{34}$. Estes achados sugerem a participação de espécies oxigenadas altamente reativas, como íons peróxido e radicais hidroxila ( $\left.\mathrm{HO}^{*}\right)$, na patogênese das manifestações clínicas destas doenças. Este efeito seria decorrente do efeito pró-oxidante do ALA, indutor da auto-oxidação da oxihemoglobina, com conseqüente prejuízo da função fisiológica mitocondrial, lipossomal, do $A D N$, e de outras proteínas ${ }^{127}$. Foi também observado experimentalmente, em fígado de ratos, acúmulo intramitocondrial de ferritina e corpúsculos de lipofucsina ${ }^{18}$, que poderiam ser resultado de processos oxidativos.

HERMES-LIMA et al. ${ }^{80}$ demonstraram que altas concentrações de ALA são capazes de induzir alterações estruturais na mitocôndria, através do aumento da permeabilidade da membrana mitocondrial, pois os lípides que a formam são particularmente sensíveis ao estresse oxidativo. A peroxidação destes ácidos graxos afeta vários processos de transporte através da membrana, como ativação de receptores, formação de segundo mensageiros, e homeostase do cálcio $\left(\mathrm{Ca}^{++}\right)^{138}$, levando ao aumento do $\mathrm{Ca}^{++}$ 
no citossol, e ativando enzimas degradadoras $\mathrm{Ca}^{++}$dependentes, como proteases, fosfolipases, e endonucleases. A lesão mitocondrial ocorre exatamente quando $\circ \mathrm{Ca}^{++}$é captado pela mitocôndria, sendo $\circ \mathrm{Ca}^{++}$ intramitocondrial o responsável por estas alterações. Além do $\mathrm{Ca}^{++}$, o íon ferro também atua como importante agente lesional na mitocôndria, pois cataliza a formação de radicais hidroxila a partir de $\mathrm{O}_{2}{ }^{-}$e $\mathrm{H}_{2} \mathrm{O}_{2}$. $\mathrm{O}$ acúmulo de ALA, induzido experimentalmente através da administração de succinilacetona, acompanha-se da elevação das quantidades de ferro no plasma, fígado e cérebro, e de ferritina no tecido hepático de cobaias. Esta intensa mobilização de ferro é também indicada pelo aumento na saturação plasmática da transferrina. Além disto, o íon peróxido tem a propriedade de causar a liberação de ferro do retículo endoplasmático e da ferritina, fornecendo íns ferro, que participariam ativamente do dano oxidativo mitocondrial ${ }^{157}$. Demonstrou-se que fosfato, EDTA e ATP aceleram a liberação de ferro promovida pelo $A L A^{158}$. As proteínas também são afetadas, principalmente os grupos sulfidril $\mathrm{e}$ as pontes dissulfide, prejudicando o funcionamento de receptores e de enzimas como as ATPases ${ }^{191}$. A disfunção mitocondrial causada pelo ALA foi comprovada in vivo por BECHARA et al. ${ }^{14}$ através da demonstração do aumento do metabolismo glicolítico hepático e muscular e do menor limiar à fadiga em ratos tratados cronicamente com ALA.

Os radicais livres têm efeito sobre a concentração de óxido nítrico, que exerce importante função como vasodilatador, inibidor da agregação plaquetária e neurotransmissor. Este é inativado pelos ânions superóxido 
$\left(\mathrm{O}_{2}-\right)$, causando constrição arteriolar e prejudicando a regulação do tônus vascular fisiológico, além de a reação entre óxido nítrico e ânions superóxido produzir peroxinitrito, o qual também pode ser uma fonte de radicais hidroxila, resultando em lesão endotelial mais extensa. A ação neurotransmissora do óxido nítrico envolve vias não-adrenérgicas nãocolinérgicas em vários sistemas, como o respiratório e o gastro-intestinal ${ }^{191}$. Portanto, alterações nestas funções poderiam causar distúrbios autonômicos na motilidade intestinal, explicando as manifestações gastro-intestinais encontradas na PAI.

A série de eventos oxidativos em estruturas celulares pode ser prevenida através da administração exógena de $\mathrm{Mg}^{++}$. Especula-se que estes processos que ocorrem na mitocôndria provavelmente teriam lugar também em tecidos como músculos, cérebro, e rins ${ }^{80}$.

Há evidências experimentais de que o acúmulo de ALA exerceria um papel carcinogênico através do dano causado ao ADN, justificando assim a elevada incidência de hepatoma encontrada em pacientes com PAI e com tirosinemia hereditária ${ }^{46}$. Este efeito mutagênico decorreria da capacidade alquelante de bases do ADN, como a guanina, causado pela ação do produto final da oxidação do ALA, o ácido 4,5-dioxovalérico.

\subsubsection{Depleção de Substratos Essencials ou de Co-fatores}

O defeito na via biossintética de produção do heme provocaria a redução na disponibilidade de algumas substâncias fundamentais para o metabolismo: 
1a) Piridoxal fosfato (vitamina B6):

É um co-fator essencial para a ALA-S. Admitindo-se que durante uma crise de PAI ocorra aumento da atividade desta enzima, haveria depleção de piridoxal fosfato, causando sua diminuição nos tecidos neurais. A favor desta hipótese há o fato de haver-se mensurado baixos níveis plasmáticos de piridoxal fosfato em alguns pacientes com PAI, porém deve-se ressaltar que o estado nutricional destes pacientes não havia sido adequadamente analisado para que fosse afastada uma deficiência nutricional prévia ${ }^{22}$. Experimentalmente, provocou-se deficiência de vitamina B6, induzindo-se assim redução da atividade da enzima ALA-S, e conseqüentemente a diminuição dos níveis urinários de ALA e PBG, os quais retornaram a níveis normais quando da administração de piridoxina. Além disso, observou-se que as características histopatológicas da neuropatia da PAI e as da deficiência de vitamina B6 apresentam algumas semelhanças. Existem porém alterações que não são observáveis nos seres humanos, como desmielinização das fibras das colunas posteriores e edema nas células de Betz do córtex motor. No total, conclui-se que as características clínicas destas duas neuropatias, porém, são suficientemente diferentes para tornar esta hipótese pouco plausível, pois enquanto a neuropatia por deficiência de piridoxina é simétrica, distal, de predomínio sensitivo e em membros inferiores, a da porfiria pode ser assimétrica, é quase que exclusivamente motora, de predomínio proximal e freqüentemente predomina nos membros superiores. Confronta-se também com esta hipótese o fato de que pacientes de um grupo controle com deficiência de vitamina B6 quantitativamente 
semelhante ao de pacientes com porfiria não desenvolvem neuropatia. Finalmente, YEUNG-LAIWAH et al. ${ }^{207}$ não encontraram baixos níveis de piridoxal fosfato em seu grupo de pacientes com PAl e estado nutricional adequado, mesmo naqueles com neuropatia.

1b) Zinco:

Este metal é excretado em grandes quantidades pela urina de pacientes porfíricos, pois as porfirinas apresentam propriedades quelantes de muitos íons metálicos divalentes ${ }^{146}$. Porém, é pouco provável que a depleção de zinco tenha algum papel na patogênese da porfiria, já que os aspectos clínicos da deficiência deste metal e da neuropatia da PAl são absolutamente diversos; além disso, a suplementação de zinco não resultou em melhora clínica nos pacientes com PAI. Observou-se ainda que nas porfirias crônicas (PCT e PPE) a excreção de zinco é maior do que na PAI, não obstante o fato de apenas esta última apresentar-se com neuropatia ${ }^{207}$. Estas alterações no metabolismo do Zn parecem, então, apresentar-se mais como epifenômeno na PAI do que como fator etiopatogênico propriamente dito.

1c) Glicina:

É um substrato para a ALA-S. Havendo excesso de atividade da ALA$S$ na crise de PAl, e maior consumo de glicina, haveria deficiência deste substrato em outras vias bioquímicas, tais como para a síntese de acetilcolina. Porém, não foi ainda comprovado que a disponibilidade da glicina ou de acetilcolina estaria diminuída. 


\subsubsection{Acúmulo de Produtos Anormais Derivados dos PRECURSORES dAs PORFIRINAS}

Foi observado que a urina de pacientes esquizofrênicos, de indivíduos expostos a níveis altos de chumbo, e com PAl sintomática, continha alguns compostos pirrólicos derivados do PBG, como hemopirrol lactama e porforbilina. Aventou-se a hipótese de que estas substâncias teriam efeito neurotóxico, e de que poderiam estar envolvidas na patogênese dos sintomas psiquiátricos. A porfobilina só é detectada na urina após sua exposição à luz, o que praticamente elimina-a como fator causal. 0 hemopirrol lactama, por sua vez, mostrou ser indutor da enzima ALA-S ${ }^{129}$, e, como tal, poderia ser incriminado como fator precipitante ou agravante da crise de porfiria. No entanto, são necessários estudos sobre os níveis plasmáticos e neurais deste composto. Contra esta hipótese há o fato de não ter sido comprovada qualquer relação quali ou quantitativa entre as concentrações urinárias destes compostos e as apresentações clínicas da porfiria, especialmente o quadro psiquiátrico ${ }^{141}$. A única manifestação que pôde ser correlacionada com níveis desses metabólitos foi a ansiedade.

\subsubsection{OUTRAs HiPÓtESES}

Atribuem-se ainda a algumas outras hipóteses os distúrbios neurológicos observados na porfiria:

Existem evidências de que as porfirinas são neurotóxicas. Segundo FRESSINAUD ${ }^{61}$, elas teriam a capacidade de ligarem-se a receptores PAULA MARZORATI KUNTZ PUGLIA 1. INTRODUÇÃO 
benzodiazepínicos, situados na membrana externa das mitocôndrias, provavelmente acoplados a um canal de $\mathrm{Ca}^{++}$voltagem-dependente, inibindo assim a respiração mitocondrial. No entanto, o fato de encontrarem-se elevadas em outras porfirias, onde as manifestações são apenas cutâneas, como a PPE, PCT e PEC, sem elevação concomitante de ALA, indica que estes compostos por si só não podem ser responsabilizados pelo quadro neurológico da $\mathrm{PAI}^{124}$.

Foi observada in vitro inibição pré-sináptica da junção neuromuscular ${ }^{54}$, pela redução da freqüência dos potenciais miniatura da placa terminal, tendo sido sugerido que o ALA e o PBG seriam capazes de inibir a liberação de acetilcolina na junção neuromuscular. Isto, porém, não é sustentado pela avaliação eletrofisiológica dos pacientes com PAI, e parece pouco provável que isto tenha alguma relação com a neuropatia observada durante as crises.

Discute-se também a possibilidade de mecanismo vascular na patogênese das lesões encontradas no SNC, pela observação anátomopatológica de focos cerebrais isquêmicos ou necróticos ${ }^{81,100}$, além da semelhança das imagens obtidas na ressonância magnética (RM) com a de vasculopatias (lúpus eritematoso sistêmico e vasculite isolada de $\mathrm{SNC})^{93}$.

KUPFERSCHMIDT et al. $^{98}$ sugeriram que a deficiência da hemoproteína óxido nítrico sintetase, produtora de óxido nítrico, um potente vasodilatador, causaria vasoespasmo e conseqüente isquemia nos lobos occipitais, parcial ou totalmente reversíveis, contrapondo-se à hipótese defendida por SZE ${ }^{179}$, na qual este autor postula que a hipertensão arterial 
sistêmica subjacente, encontrada nos episódios de PAl, em alguns casos acompanhando o início do quadro neurológico, poderia causar encefalopatia, predominando nas regiões cerebrais posteriores, como é a topografia do acometimento aqui descrito.

\subsection{Neuropatologia}

Nas autópsias de pacientes falecidos durante os surtos de porfiria não foram encontradas lesões patológicas significativas no sistema nervoso ${ }^{78}$, sugerindo que os distúrbios metabólicos são a alteração mais importante na fase inicial, e que as alterações histológicas só são evidentes em fases mais adiantadas e severas deste processo. O fato de muitos dos pacientes terem sofrido vários ataques de porfiria dificulta a interpretação dos resultados histopatológicos, já que há somação de alterações crônicas e agudas. Existe, por este motivo, necessidade de avaliação criteriosa que diferencie as alterações decorrentes da própria doença daquelas atribuíveis a outros fatores, como insuficiência renal e hipóxia secundária a insuficiência respiratória.

\subsubsection{Nervos Periféricos}

Não há lesões estruturais patognomônicas da PAI. Em geral, estas seguem o padrão de processos tóxicos, com envolvimento de múltiplas áreas do sistema nervoso. O primeiro estudo de autópsia em paciente com PAI, precipitada por sulfa, data de $1903^{52}$. Na ocasião, foi notada 
degeneração axonal com focos de desmielinização no nervo femoral. É ainda controverso se a alteração patológica primária ocorre na bainha de Schwann ou no axônio. A maioria dos estudos, no entanto, considera que a lesão axonal distal é o evento inicial, tanto em estudos de autópsia quanto em biópsias neurais ${ }^{30}$. Foi proposto que o mecanismo de lesão da neuropatia seria do tipo "dying-back", com o evento tóxico primeiramente ocorrendo no corpo celular, seguido de ruptura do eixo da célula nervosa ${ }^{30}$ ${ }^{180}$, e a desmielinização seguiria o efeito no pericariócito. THOMAS ${ }^{182}$ relata ter observado em biópsias de nervos de pacientes porfíricos um grau moderado de desmielinização, predominantemente paranodal, mas também segmentar. As fibras motoras mais grossas e mielinizadas são as primeiras a sofrerem, assim como em outros tipos de afecções, sendo que as fibras sensitivas de menor calibre são mais resistentes à agressão, e, quando acometidas na porfiria, o são provavelmente por atravessarem regiões especialmente afetadas nos nervos. GIBSON e GOLDBERG ${ }^{65}$ realizaram um estudo neuropatológico detalhado em cinco casos autopsiados, e observaram desmielinização maciça nos nervos periféricos, de caráter segmentar, acometimento difuso e sem predileção topográfica, enquanto os axônios apresentavam-se íntegros ou com alterações insignificantes em alguns casos, e com lesões mais intensas em outros, porém sempre em menor grau que o demonstrado na célula de Schwann. CAVANAGH e MELLICK ${ }^{30}$, numa visão mais aceita atualmente, questionaram esses achados, argumentando que seria impossível que uma afecção desmielinizante primária afetasse seletivamente apenas o componente 
motor de nervos mistos, envolvidos por uma bainha única de mielina. Estes autores encontraram, em quatro casos autopsiados, apenas fibras normais ou sofrendo degeneração walleriana, sem qualquer desmielinização de padrão segmentar. Mesmo muito tempo após o início da paralisia motora, observaram-se alterações degenerativas em estágios iniciais, indicando que o processo lesional ainda não estava completo quando do início do déficit motor. Num estudo mais recente, ANZIL e DOZIC ${ }^{7}$ concluem que a degeneração axonal e a desmielinização são eventos praticamente indissociáveis e simultâneos nesta doença, através de exame de nervo sural obtido em biópsia, negando que a desmielinização seja secundária à degeneração axonal, embora tenham notado acometimento do axônio com freqüência relativamente maior, e admitam que os dois padrões lesionais podem afetar as fibras nervosas concomitante ou separadamente.

Existe um fato paradoxal nos achados de que os axônios motores mais curtos, como os dos nervos cranianos e da musculatura proximal dos membros são os primeiros a serem comprometidos, em contraste com as alterações distais precoces encontradas nas neuropatias axonais de etiologia metabólica, como o diabete melito, que acometem inicialmente os axônios mais longos. Isto pode implicar que o distúrbio primário talvez ocorra nas raízes ou no pericariócito. Nas raízes ventrais e dorsais encontraram-se diversos graus de degeneração. Após o sexto dia da instalação da neuropatia periférica ocorre desmielinização das raízes motoras, e inicialmente os axônios ainda estão intactos. Neste caso a recuperação motora pode ser completa, em semanas ou poucos meses ${ }^{1}$. HIERONS ${ }^{81}$ 
compilou dados da literatura e concluiu que, embora as células neuronais da medula e das raízes possam estar normais ou terem sofrido cromatólise, nunca são totalmente destruídas.

Praticamente em todos os músculos examinados por CAVANAGH e MELLICK $^{30}$ foi observada desnervação total ou quase total. Somente na musculatura paravertebral cervical foram encontradas terminações nervosas motoras íntegras com alguma freqüência.

\subsubsection{Medula}

$\mathrm{Na}$ ponta anterior da medula observa-se perda de neurônios e cromatólise celular $^{65}$, explicada por HIERONS ${ }^{81}$ através da degeneração retrógrada causada pela degeneração axonal. Não há nível medular preferencialmente acometido. Não foi descrita desmielinização na medula.

\subsubsection{Sistema Neurovegetativo}

GIBSON e GOLDBERG ${ }^{65}$ e PERLROTH et al. ${ }^{142}$ descreveram desmielinização no nervo vago em dois de seus casos, e nas fibras da cadeia simpática em um deles, sem qualquer alteração axonal. Foi observada cromatólise também nos neurônios do tronco cerebral, principalmente no núcleo dorsal do vago, e nos gânglios do SNV (por exemplo, no gânglio celíaco).

Vários autores, entre eles GOLDBERG ${ }^{66}$, propuseram uma causa neurogênica para as manifestações que abrangem os distúrbios vesicais e 
os sistemas gastro-intestinal e cardiovascular, embasados em alguns achados patológicos: alterações degenerativas em células motoras préganglionares da medula e bulbo, desmielinização do nervo vago e de fibras da cadeia simpática.

\subsubsection{EnCÉFALO}

No cérebro, observa-se perda neuronal difusa. GIBSON e GOLDBERG $^{65}$ relatam desmielinização na substância branca cerebral em três dos cinco casos por eles analisados, assim como cromatólise em neurônios do córtex e dos núcleos da base, e gliose, porém sempre em menor grau que a encontrada no bulbo e medula. Os focos de desmielinização ocorrem, segundo estes autores, preferencialmente ao redor de vasos sangüíneos, havendo degeneração axonal em menor extensão.

O lobo parietal é o mais comumente afetado, porém encontram-se alterações também nos lobos occipital e frontal. LAI et al. ${ }^{100}$ relataram um caso de amaurose cortical com gliose e perda de células ganglionares no córtex visual primário bilateralmente, além de desmielinização proeminente na substância branca do córtex visual. HIERONS ${ }^{81}$ descreveu também importante lesão focal em todas as camadas do córtex occipital em um de seus pacientes, não mencionando porém qualquer alteração visual. O setor de Sommer e o hipocampo foram examinados em dois casos, encontrandose intactos, assim como as meninges. Lesões hipotalâmicas também foram 
descritas, nos núcleos supraóptico e paraventricular, com perda neuronal de $95 \%$ e $65 \%$, respectivamente ${ }^{142}$. Não existem estudos histopatológicos recentes, que empreguem técnicas morfológicas, histoquímicas e ultraestruturais modernas.

KLÜVER $^{94}$ apud TSCHUDY et al. ${ }^{189}$ demonstrou a presença de coproporfirina III no sistema nervoso de indivíduos normais, descrevendo o que chamou de "porfirinização" ascendente durante o desenvolvimento. Com base neste dado, PETERS et al. ${ }^{145}$ sugeriram que nos pacientes com PAI talvez o sistema nervoso esteja depletado de porfirinas, que têm papel na condução nervosa e na manutenção da bainha de mielina. No bulbo, alterações cromatolíticas foram observadas nos núcleos ambíguo e do trato solitário, e na substância reticular, assim como no núcleo oculomotor no mesencéfalo.

\subsection{Fisiopatologia}

\subsubsection{Sistema Neurovegetativo}

Considera-se que as alterações no SNV são a causa primária dos distúrbios gastro-intestinais. Estas alterações seriam provocadas por aumento da atividade do SNV simpático, elevando a concentração de catecolaminas, ou por alterações estruturais no núcleo do vago. Observouse, durante laparotomia realizada na crise de porfiria, em alguns pacientes, espasmo intestinal alternado com atonia e dilatação, em localizações variáveis. Esta atonia foi observada também no segmento esofágico. $O$ PAULA MARZORATI KUNTZ PUGLIA 
vasoespasmo foi citado por LITHNER $^{107}$ como possível mecanismo responsável pela dor abdominal. Este autor descreveu um caso fatal de PAI com dor abdominal severa, no qual foi observado um segmento intestinal necrótico à autópsia, devido provavelmente a infarto tecidual. Foi demonstrado que a administração de drogas neurotóxicas a cobaias causou degeneração extensa de células ganglionares do plexo mioentérico, levando a dilatação gástrica, atonia intestinal e íleo paralítico, tal qual ocorre em crises de $\mathrm{PAI}^{16}$. Estes autores postularam que as alterações verificadas no núcleo do vago podem ter papel importante na gênese da dor abdominal, pois as fibras pré-ganglionares motoras que inervam as vísceras têm seus corpos neuronais na medula e no bulbo, encontrando-se estas estruturas comumente afetadas nas crises porfíricas. É ainda controverso se o distúrbio afeta predominantemente o SNV simpático ou o parassimpático. A vagotomia e a porfiria exercem efeitos semelhantes sobre o peristaltismo intestinal, suspeitando-se que o SNV parassimpático seja o mais acometido nesta última condição, pois é o responsável pelos principais distúrbios funcionais: a atonia e a dilatação. É provável que haja disfunção parcial da inervação motora, tornando a motilidade intestinal irregular, assim levando ao quadro álgico. Isto explicaria o alívio temporário em seguida à administração de neostigmina ou de agentes bloqueadores ganglionares ${ }^{68}$. Por outro lado, segundo outros autores ${ }^{146}$, a dor abdominal seria causada pelo acúmulo de ácido lático, em decorrência da formação de complexos entre as porfirinas circulantes e o zinco sérico. 
Alguns estudos com jejuno de ratos sugerem que a interação entre os neurotransmissores GABA e glutamato e o ALA e seus receptores no plexo mioentérico poderia justificar os distúrbios na motilidade gastro-intestinal observados nas crises $^{124}$.

A hipertensão arterial é possivelmente explicada pela presença de lesões nas fibras aferentes mielinizadas dos seios carotídeos e aórticos no IX e no $X$ nervos cranianos. A desmielinização interromperia o fluxo fisiológico de estímulos inibitórios destes seios, levando ao aumento da pressão arterial. Analogamente, infere-se que a taquicardia também seja um sintoma decorrente da neuropatia autonômica e da desnervação dos barorreceptores $^{153}$, o que pode ser reforçado pelo fato destas duas manifestações ocorrerem muito próximas temporalmente.

A neuropatia autonômica foi recentemente estudada através da demonstração das alterações dos reflexos cardiovasculares na PAI por YEUNG-LAIWAH et al. ${ }^{206}$, e BLOM et al. ${ }^{20}$. Alguns pacientes excretam grande quantidade de epinefrina e norepinefrina na urina, atingindo níveis semelhantes àqueles encontrados no feocromocitoma. Observa-se que a elevação de catecolaminas durante a crise correlaciona-se com a hipertensão arterial, e também com o hiperaldosteronismo, por estimulação da secreção de renina no aparelho justa-glomerular, embora a razão deste aumento seja desconhecida. Uma explicação seria a alteração na recaptação de noradrenalina pelos neurônios adrenérgicos, provocada pelo ALA e $P B G^{89}$. 
A serotonina, cujos níveis estão elevados nas crises de PAI, age no sistema neurovegetativo, sendo, em particular, responsável por alterações na função de vários sistemas: no gastro-intestinal, pela contração e relaxamento da musculatura da parede intestinal; no cardiovascular, causando hipertensão e arritmias; e, por último, sendo também modulador da função vesical ${ }^{124}$.

BLOM et al. $^{20}$ estudaram a função autonômica de pacientes portadores (sintomáticos e assintomáticos) de PAl, e observaram alterações sugestivas de disfunção parassimpática, tanto nas crises quanto nos períodos intercríticos, o que pode estar intimamente relacionado aos quadros de arritmia e morte súbita nestes pacientes.

\subsubsection{Sistema Nervoso Periférico}

A degeneração axonal observada nos nervos periféricos seria decorrente de um acometimento do tipo "dying back". O agente agressor atuaria no corpo neuronal, prejudicando o transporte adequado de substâncias necessárias à sobrevivência de porções mais distais do axônio, nas quais o processo degenerativo se iniciaria, e a partir de onde a lesão estender-se-ia mais proximalmente.

No sistema nervoso periférico, ocorreria uma alteração no metabolismo celular, em particular do transporte axonal, em decorrência do distúrbio energético causado pela deficiência de heme, possivelmente pela inibição da bomba de $\mathrm{Na}^{+}$e $\mathrm{K}^{+}$, levando posteriormente à redução dos potenciais evocados à estimulação elétrica nos nervos periféricos e raízes 
dorsais e ventrais, em decorrência da degeneração axonal distal e morte celular. Não existem estudos aprofundados sobre a capacidade de penetração do heme no SNP. No entanto, não se observam alterações neuronais difusas, como seria esperado, nem os achados patológicos são semelhantes àqueles encontrados na hipoglicemia ou na hipóxia, cujos mecanismos lesionais seriam similares quanto à disfunção no metabolismo oxidativo celular ${ }^{205}$. A deficiência de heme foi demonstrada em biópsias musculares de pacientes com $\mathrm{PAI}^{124}$.

Por outro lado, demonstrou-se que a administração de repetidas doses de ALA a cobaias desencadeou fadigabilidade precoce nestes animais, quando submetidos a testes de exercícios de natação ${ }^{13}$, sugerindo que este precursor possa também ter um papel significativo na paresia exibida em crises de PAI.

\subsubsection{Sistema Nervoso Central e Manifestações Psiquiátricas}

As alterações no nível de consciência são atribuídas ao defeito metabólico primário, decorrente da deficiência de heme ou do excesso de ALA, embora ainda não se conheça a ação exata destes distúrbios bioquímicos sobre as estruturas cerebrais, e nem o mecanismo pelo qual eles podem produzir lesões neste sistema. Esta última é uma das hipóteses mais aventadas atualmente, considerando a possibilidade de alguns sintomas, como as alterações da esfera cognitiva, distúrbios psiquiátricos, crises convulsivas e as alterações autonômicas, serem decorrentes da 
elevação dos níveis de ALA. Este precursor tem grande semelhança estrutural e é agonista parcial do GABA, que é o principal neurotransmissor inibitório do sistema nervoso central.

Em algumas ocasiões a encefalopatia é decorrente de distúrbios hidroeletrolíticos, principalmente da redução do sódio sérico. Em geral esta manifestação é transitória, citando-se como exemplo o relato de uma paciente com hiponatremia de $108 \mathrm{mmol} / \mathrm{l}$, comatosa e com papiledema, cuja recuperação do nível de consciência ocorreu rapidamente após reposição eletrolítica e elevação do sódio para $129 \mathrm{mmol} / \mathrm{l}^{45}$. As crises convulsivas também podem ser decorrentes da hiponatremia, ou mesmo de epilepsia idiopática associada.

O acometimento preferencial das regiões cerebrais posteriores é provavelmente responsável pela agnosia visual $^{45}$, e amaurose cortical $^{98,100}$ descritas. Estes autores descreveram um caso de amaurose cortical de início súbito, com lesões occipitais extensas ao estudo anátomo-patológico.

No SNC, a serotonina está relacionada a alterações do humor, como depressão e ansiedade. Há aumento dos níveis deste neurotransmissor e do seu precursor, o triptofano, na $\mathrm{PAI}$, devido à redução da atividade da enzima triptofano pirrolase. A serotonina pode também estar relacionada à anorexia e perda de peso ocasionalmente encontrados nestes pacientes. Estes autores concluem que muitas das manifestações encontradas na PAI são semelhantes às encontradas quando há exacerbação da atividade serotoninérgica. 
A redução nos níveis de melatonina observada em alguns pacientes com PAI pode ser responsável pelos distúrbios do sono presentes nas fases iniciais da crise, como a insônia. Esta substância é responsável pela manutenção do ciclo vigília-sono e de outros ritmos circadianos, sendo que em condições normais a sua secreção é maior no período noturno, quando é indutora do sono ${ }^{148}$.

Segundo PATIENCE et al. ${ }^{141}$, as alterações da esfera mental poderiam ser conseqüência da elevação de metabólitos das porfirinas no sistema nervoso central, ou, então, atribuídas diretamente a uma mutação no gene da URO-S, ou em um gene a ele relacionado. No entanto, este autor demonstrou que não há diferença significativa entre pacientes ou portadores de PAl e a população geral, quanto à incidência de distúrbios psiquiátricos, especificamente esquizofrenia e doença maníaco-depressiva, havendo, porém, correlação direta entre o nível de ansiedade e excreção urinária de metabólitos de porfirinas, sugerindo que a PAl deve ser considerada no diagnóstico diferencial de distúrbio generalizado de ansiedade.

\subsubsection{MANIFESTAÇÕES SistêMICAS}

As alterações hidroeletrolíticas podem ser resultado da interação de múltiplos fatores. As lesões no eixo hipotálamo-hipofisário podem levar a aumento da liberação do hormônio anti-diurético (HAD), com conseqüente alteração na concentração eletrolítica normal. SUAREZ et al. ${ }^{177}$ descreveram um paciente, acompanhado desde os 8 anos de idade, com vários episódios PAULA MARZORATI KUNTZ PUGLIA 
de hiponatremia nas crises da doença, e estudaram os aspectos clínicos e suas possíveis correlações patológicas. Não havia poliúria ou sinal de desidratação, tendo a investigação complementar afastado nefropatia, e o diagnóstico final foi síndrome de secreção inapropriada de hormônio antidiurético (SIHAD). Após 31 anos, o paciente faleceu, e o estudo anátomopatológico revelou redução em mais de $75 \%$ da população celular do hipotálamo, com astrocitose reacional no núcleo supraóptico, e maior que $90 \%$ nos paraventriculares.

Além da causa central, menos freqüente, a hiponatremia em muitos casos é decorrente de perdas gastro-intestinais, sobrecarga hídrica, e, secundariamente, embora ainda não comprovado, poderiam também ocorrer lesões renais, que causariam perda de sódio, e a hipovolemia decorrente estimularia a secreção de $\mathrm{HAD}^{189}$. A disfunção hipotalâmica, resultando em secreção inapropriada de hormônio anti-diurético e conseqüente hiponatremia, é observada em aproximadamente $40 \%$ dos casos de PAI que cursam com hiponatremia ${ }^{174}$.

A hipomagnesemia e a hipocalcemia foram atribuídas por HELLMAN et al. $^{79}$ à retenção hídrica observada na SIHAD, induzindo aumento da calciúria; e às perdas renais, pois a hipomagnesemia pode ser induzida pela competição por reabsorção tubular por outros cátions divalentes, como o cálcio, provavelmente associado a diminuição da ingesta e também a perdas gastro-intestinais.

A galactorréia é um sinal que TSCHUDY et al. ${ }^{189}$ atribuem à disfunção hipotalâmica, e, em alguns casos, à administração de fenotiazínicos. 


\subsection{Diagnóstico}

A inespecificidade dos sintomas encontrados na crise de PAI não possibilita a certeza do diagnóstico baseado apenas no quadro clínico, sendo necessários critérios laboratoriais específicos que confirmem a suspeita. Deve-se ressaltar, porém, que os parâmetros para diagnóstico das porfirias não estão ainda claramente estabelecidos.

\subsubsection{BIoquímico}

As porfirias são caracterizadas bioquimicamente pela elevação dos precursores do heme no sangue, na urina e/ou nas fezes. A presença por si só destas substâncias não estabelece o diagnóstico de porfiria, pois todos os animais excretam porfirinas e seus precursores na urina.

Durante as crises de PAI, quantidades maiores do que o normal de ALA e PBG são excretadas na urina, geralmente entre 50 e 200 mg/dia de PBG, e aproximadamente a metade deste valor de ALA. Ao contrário de algumas outras formas de porfiria, como a variegada e a coproporfiria, na PAl não se observa aumento da excreção fecal de porfirinas, embora recentemente ROSSI ${ }^{161}$ tenha observado aumento da excreção de URO nas fezes de três pacientes, durante ataque de PAI, atribuindo-a à condensação do PBG produzido em excesso durante a crise, excretado pela bile. $\mathrm{Na}$ vigência de crise, em alguns casos, os níveis de URO e COPRO também 
encontram-se aumentados na urina, embora estas porfirinas detectadas na urina provavelmente tenham origem no metabolismo dos precursores em tecidos não hepáticos. Devido à indução da enzima ALA-S, os níveis de COPRO e URO podem estar elevados até mesmo em pessoas não portadoras de porfiria, mas que estejam fazendo uso de medicações como sulfonas, barbitúricos, fenitoína, primidona, estrógenos, sulfas e seus derivados. Esta observação deu origem à hipótese de que a PAl é o primeiro, até hoje identificado, erro inato do metabolismo a ser causado pela hiperatividade de uma enzima ${ }^{188}$.

Na urina recém-colhida, o PBG é incolor, porém, em pH ácido, e sob ação de calor e de luz solar, pode haver polimerização e formação de porfirinas e outros pigmentos, como a uroporfirina e a porforbilina, sendo esta última um produto da degradação espontânea do PBG. Estas substâncias tornam a urina do paciente com PAl avermelhada. Este fato é a base para um teste de simples realização, chamado "teste do parapeito da janela", onde a urina de um paciente suspeito de PAl é exposta à luz solar, observando-se se há mudança na sua cor, no prazo máximo de um ou dois dias, embora geralmente este processo ocorra entre 30 e 120 minutos.

O teste de Watson-Schwartz é amplamente utilizado como forma de triagem em pacientes com quadro clínico suspeito de PAI. Consiste na reação entre PBG e o reagente aldeído de Ehrlich (p-dimetilaminobenzaldeído em solução fortemente ácida), na qual ocorre formação de um pigmento vermelho, que não é passível de extração com clorofórmio ou butanol. Há possibilidade de falsos-positivos neste teste, principalmente 
quando o nível de urobilinogênio urinário é elevado, a menos que extrações apropriadas sejam realizadas previamente. Algumas drogas, como a clorpromazina, também podem resultar em falsos-positivos. Outros compostos também podem interferir na determinação deste resultado. SCHOENFELD et al. ${ }^{169}$ sugerem que a maior especificidade do resultado é obtida através da análise de urina de 24 horas, ao invés da de amostras isoladas.

O teste de Hoesch ${ }^{101}$ foi proposto como alternativa ao de WatsonSchwartz, pois é de fácil realização, e tão sensível quanto o primeiro, além de não apresentar reações cruzadas com o urobilinogênio. É também conhecido como "reação reversa de Ehrlich", em contraponto ao teste de Watson-Schwartz, a "reação convencional de Ehrlich", e consiste na utilização do mesmo reagente ( $p$-dimetil-aminobenzaldeído) que esta última, porém elimina a etapa de extração do urobilinogênio, necessária após a reação. Deve-se recordar que o diagnóstico de PAl não pode ser afastado apenas pela negatividade do teste de Watson-Schwartz, embora a sensibilidade do teste seja maior que sua especificidade, seja na crise ou na pesquisa de portadores assintomáticos. A sensibilidade deste teste encontra-se reduzida principalmente nos períodos intercríticos. Mesmo nos surtos os testes de Watson-Schwartz e Hoesch habitualmente só tornam-se positivos quando a concentração de PBG é maior que $9 \mathrm{mg} / \mathrm{l}^{48,171}$. É aconselhável que após a positividade do teste de Watson-Schwartz seja realizada a dosagem de PBG e ALA urinários, pois são testes mais específicos. A análise quantitativa dos precursores ALA e PBG na urina 
recém-colhida é o método mais simples e talvez o melhor, atualmente, para firmar o diagnóstico diante de um quadro suspeito de porfiria. Esta excreção pode dar-se de forma contínua, intermitente ou ser de curta duração, e não ter necessariamente relação direta com a fase do quadro clínico pela qual o paciente está passando. Assim sendo, alguns pacientes podem apresentar eliminação de quantidades muito grandes destes precursores na urina, enquanto são assintomáticos, ou mesmo estando em fase de remissão, enquanto muito mais raramente outros podem excretar volumes praticamente normais de ALA e PBG, durante crises muito graves ou até mesmo fatais.

As amostras de urina de 24 horas não fornecem dados precisos, pois os precursores passam a porfirinas maturadas neste período, mesmo no interior da bexiga urinária. O método de dosagem de ALA na urina descrito por TOMOKUNI e OGATA ${ }^{186}$, através de leitura por espectrofotometria, é superior ao de MAUZERALL e GRANICK ${ }^{117}$ em relação à simplicidade, havendo boa correlação entre estes dois. O último utiliza coluna de troca iônica, e é uma técnica inadequada para análise de muitas amostras pelo grande tempo empregado para realizá-la ${ }^{164}$. Embora a dosagem deste precursor possa estar normal entre os ataques, em um estudo conduzido por STEIN e TSCHUDY ${ }^{174}$, com 46 pacientes, isto ocorreu em apenas um, que estava em período de grande ingestão de carboidratos. A normalidade na dosagem de PBG na urina durante a crise é forte evidência contra o diagnóstico de PAI. Valores acima de 2 mg/litro para PBG e 4 mg/litro para ALA significam que os testes devem ser repetidos e o paciente observado. 
Valores acima de $150 \mu \mathrm{g} / \mathrm{litro}$ de COPRO e $40 \mu \mathrm{g} / \mathrm{litro}$ de URO podem ser significativos.

MINDER $^{126}$ estabeleceu um método diagnóstico mais sensível de quantificação de ALA, utilizando cromatografia líquida de alta performance (HPLC) de fase reversa com detecção de fluorescência ultravioleta. Este método explora a diferença na solubilidade das porfirinas. Recentemente, HINDMARSH et al. ${ }^{83}$ estudaram a validade da dosagem de porfirinas no plasma de pacientes com vários tipos de porfiria, utilizando HPLC como método diagnóstico alternativo à dosagem na urina e fezes, e constataram que na PAI não havia alteração quantitativa das várias frações de porfirinas, ou então a variação nos níveis era pouco significativa nas uroporfirinas I e III e coproporfirinas I e III, concluindo que este método é de pouco auxílio no diagnóstico das porfirias agudas, e de grande valor na detecção da PCT.

No plasma de indivíduos normais o ALA e o PBG não são detectados, pois encontram-se ausentes ou em níveis muito baixos (10 $\mu \mathrm{g} / \mathrm{dl}$ ou menos), enquanto que nas crises de PAI os níveis de PBG elevam-se, atingindo até $300 \mu \mathrm{g} / \mathrm{dl}$, e o ALA, até a metade deste valor. Na intoxicação por chumbo ocorre uma inversão destas proporções.

O problema do diagnóstico em pacientes assintomáticos, com exames cuja sensibilidade não é de $100 \%$, como o teste de WatsonSchwartz e a dosagem de PBG, foi resolvido com o desenvolvimento da técnica para dosagem da enzima deficitária, a URO-S, nos eritrócitos ${ }^{125}$, e em culturas de fibroblastos ${ }^{167}$. Recentemente, GRO $\beta$ et al. ${ }^{73}$ estudaram o comportamento desta enzima em 385 pacientes com PAI, e constataram que PAULA MARZORATI KUNTZ PUGLIA 1. INTRODUÇÃO 
$87 \%$ tinham entre 40 e $60 \%$ da atividade enzimática normal, $8 \%$, valores limítrofes, e 5\%, valores normais nos eritrócitos, embora a excreção urinária dos precursores seja aproximadamente a mesma nestes três grupos de pacientes, e significativamente diferente da encontrada na população de indivíduos normais. O grupo com valores enzimáticos normais nos eritrócitos corresponde a uma série de mutações próximas ao e no exon 1. Uma aplicação interessante desta técnica é a sua dosagem em crianças, pois antes da puberdade a excreção urinária de PBG é normal na PAI latente; portanto, os meios para diagnóstico nestes pacientes são a dosagem da enzima deficitária, ou a análise do ADN. KOSTRZEWSKA e GREGOR ${ }^{96}$ calcularam que $26,1 \%$ dos diagnósticos de PAl em 593 pacientes adultos, e 95,6\% das crianças, não teria sido possível sem a dosagem enzimática. Além disso, o diagnóstico pré-natal da deficiência enzimática também é possível através da análise de células amnióticas em fetos a partir de 17 semanas $^{167}$. A dosagem da enzima URO-S apresenta duas desvantagens: em primeiro lugar, existe uma sobreposição de valores entre o valor mínimo encontrado em pessoas normais, e o limite máximo da dosagem encontrada nos pacientes com PAl; em segundo, a atividade enzimática decai rapidamente de acordo com a idade do eritrócito, o que pode falsear o resultado em portadores de doenças hematológicas, com hemólise e aumento da eritropoiese. O mesmo ocorre em indivíduos com insuficiência renal crônica, poliartrite crônica, hepatites agudas ou crônicas, e em crianças abaixo de oito meses de idade. Uma técnica promissora, que pode superar 
estas eventuais desvantagens, é a dosagem da enzima em linfócitos, e que ainda está sendo estudada ${ }^{73}$.

Para determinar as características da enzima URO-S eritrocitária, foram realizados estudos imunológicos, que revelaram a existência de quatro tipos de mutações da mesma em relação ao "cross reacting immunological material" (CRIM), numa reação que utiliza anticorpos antiURO-S humana 5 :

1) CRIM negativo tipo I: Na maioria dos indivíduos heterozigotos com PAI, a quantidade de proteína enzimática imunorreativa corresponde à atividade enzimática da URO-S, indicando a ausência de CRIM produzido pelo alelo mutante. Nestes pacientes, a atividade enzimática da URO-S é de $50 \%$.

2) CRIM negativo tipo II: São pacientes sintomáticos com aumento nos níveis de ALA e PBG urinários, e níveis normais de URO-S.

3) CRIM positivo tipo I: Esta mutação apresenta-se com uma relação CRIM/atividade enzimática de aproximadamente 1,7.

4) CRIM positivo tipo II: São observados níveis muito elevados de proteína imunorreativa, e a relação CRIM/atividade enzimática é de aproximadamente 5,7 .

Estes achados sugeriram a presença de diferentes mutações alélicas no gene da URO-S, demonstrando a heterogeneidade molecular da $\mathrm{PAI}^{43}$.

O líquor é normal nos pacientes com PAI, embora alguns possam apresentar elevação dos níveis de proteína ${ }^{8}$. 


\subsubsection{MOLECULAR}

A mais importante aplicação do diagnóstico através da análise molecular é a detecção de portadores do gene, muitos dos quais assintomáticos e muitas vezes com diagnóstico laboratorial inadequado pelos métodos usuais. Os métodos laboratoriais tradicionais de dosagens de substâncias na urina contém uma série de limitações intrínsecas, com especificidade e sensibilidade relativamente baixas. Além disso, existem variáveis como atividade da doença e variabilidade individual. Em 95\% dos casos detectados através da dosagem da enzima URO-S houve confirmação do diagnóstico através do estudo genético ${ }^{149}$.

A área de interesse do gene é amplificada pela técnica de reação de polimerase em cadeia, e o material obtido é então testado para mutação. Uma vez identificada a mutação, todos os membros da família podem ser examinados. Atualmente, o uso de técnicas moleculares para o diagnóstico das porfirias neurológicas encontra-se restrito àqueles laboratórios que realizam pesquisas nesta área ${ }^{170}$, embora na prática já permitam a identificação dos pacientes e portadores na família ${ }^{35}$. PUY et al. ${ }^{147}$ descreveram um método relativamente rápido para detecção de mutações no gene da URO-S, através de eletroforese por gradiente de denaturação em gel, de maior utilidade na identificação de um grande número de pacientes e familiares. A limitação do uso mais difundido desta técnica encontra-se principalmente na grande heterogeneidade molecular e no grande número de mutações detectadas até o presente momento. 


\subsubsection{ELETROFISIOLÓGICO}

Não existe alteração eletroneuromiográfica patognomônica da neuropatia periférica da PAI ${ }^{22,207}$. Aproximadamente $50 \%$ dos pacientes com PAI apresentam um quadro de neuropatia axonal aguda, com acometimento mais intenso na musculatura axial e proximal dos membros. Embora discreta, alteração sensitiva pode estar presente, também predominando proximalmente.

As velocidades de conduções motoras e sensitivas são na maioria dos casos normais, e apenas $25 \%$ dos pacientes apresentam algum grau de alentecimento na condução nervosa, geralmente discreto, temporário, e na presença de tetraparesia importante. Embora este aspecto denote certo grau de desmielinização, esta provavelmente é secundária à degeneração axonal, conforme os achados de FLÜGEL e DRUSCHKY ${ }^{58}$, que estudaram 10 pacientes com neuropatia periférica, e concluiram que a redução da velocidade de condução em alguns pacientes está sempre dentro do limite esperado em relação à degeneração axonal. $\mathrm{O}$ exame eletroneuromiográfico, porém, mensura apenas a velocidade de condução das fibras mais rápidas, existindo um estudo ${ }^{134}$ no qual foi medida a velocidade de condução das fibras mais finas, de condução mais lenta, dos nervos ulnar (motoras e sensitivas) e mediano (sensitiva), analisando-as por bloqueio antidrômico parcial. Neste trabalho, observou-se que a velocidade com que estas fibras nervosas conduziam os impulsos era muito menor do que nos pacientes controle, embora nenhum dos pacientes fosse sintomático 
no momento do estudo. Isto leva à conclusão de que pode existir uma neuropatia periférica discreta nas formas latentes de porfiria, mesmo em pacientes que nunca apresentaram sintomas; porém, estes dados ainda não foram confirmados. Os potenciais evocados motores têm amplitudes normais ou reduzidas, geralmente em relação direita com o grau de paresia ${ }^{3}$. Redução nas amplitudes reflete perda de axônios e conseqüente atrofia muscular. Entre oito pacientes estudados, ALBERS et al. ${ }^{3}$ encontraram amplitudes diminuídas em sete deles. Já as amplitudes dos potenciais sensitivos encontraram-se diminuídas em $50 \%$ dos casos, com latências preservadas, confirmando a relativa conservação das fibras sensitivas. As ondas $\mathrm{F}$ podem ter tempo de latência normal ou discretamente aumentado, e o reflexo $\mathrm{H}$, quando presente, tem baixa amplitude, mas tempo de latência normal. Apesar da demonstração in vitro de que há inibição da transmissão neuromuscular ${ }^{54}$, e de relatos isolados de exacerbação da facilitação póstetânica em comparação com indivíduos normais, os testes de estimulação repetitiva são normais nos pacientes com PAI, como foi demonstrado por ALBERS et al. ${ }^{3}$.

O exame eletromiográfico é anormal em praticamente todos os pacientes com neuropatia periférica, evidenciando sinais de desnervação em abundância, que costumam surgir no mínimo 1 a 2 semanas após o início do quadro, com ondas positivas, fibrilações e descargas de alta freqüência, presentes nos quatro membros e na musculatura paravertebral, predominando precocemente na musculatura proximal dos membros, o que, segundo ALBERS et al. ${ }^{3}$, sugere que a lesão mais significativa ocorre na raiz 
ou na medula, ou que as células nervosas das maiores unidades motoras foram as mais vulneráveis à lesão. Sinais de reinervação, como potenciais polifásicos longos e de grande amplitude, ocorrem após algumas semanas do início da neuropatia periférica. Em pacientes com acometimento de nervos cranianos, o estudo eletroneuromiográfico dos nervo faciais demonstra potenciais evocados com amplitudes normais ou reduzidas, tempos de latências motoras normais, e sinais de desnervação ao eletromiograma.

FLÜGEL e DRUSCHKY ${ }^{58}$ observaram em alguns casos sinais de desnervação mesmo alguns anos após a crise de PAl, indicando, quando associados à ausência de potenciais motores, que o processo de reinervação ainda não havia ocorrido.

\subsubsection{RADIOLÓGICO}

Encontram-se poucas descrições de alterações na RM de encéfalo durante o episódio de PAI. Uma delas foi feita por KING e BRAGDON ${ }^{93}$, relatando a presença de múltiplas lesões, com aumento de sinal na seqüência T2, predominando nas regiões parietais e, em menor intensidade, nos lobos frontais, durante a crise de PAI, e que involuíram no exame subseqüente à melhora clínica, ocorrida em 10 dias, após tratamento com hematina. As manifestações clínicas referentes ao SNC constituíam-se de alteração no nível de consciência, crises convulsivas, e alucinações. KUPFERSCHMIDT et al. ${ }^{98}$ relataram imagens com aspecto semelhante, 
envolvendo os lobos occipitais, em paciente com amaurose cortical, também com caráter transitório. SUSA et al. ${ }^{178}$ descreveram um aspecto na RM sugestivo de necrose cortical laminar no território das artérias cerebrais médias, atribuído a provável isquemia induzida por vasoespasmo, relacionado à encefalopatia da porfiria. Além deste achado, foi também observada mielinólise pontina e extra-pontina, na região do núcleo caudado e do putamen, atribuída à rápida correção de hiponatremia severa, de 94 mEq/l para $124 \mathrm{mEq} / \mathrm{l}$ em 48 horas. Em 1995 BLACK et al. ${ }^{19}$, através de estudo angiográfico por cateter e por RM, demonstraram o caráter transitório das alterações vasculares responsáveis pela encefalopatia porfírica, concluindo tratar-se de vasculopatia isquêmica, provavelmente relacionada ao vasoespasmo evidenciado nestes exames.

\subsection{TRATAMEnTO}

Pode-se dividir o tratamento desta doença em três categorias: profilaxia, controle dos sintomas e de complicações da crise, e reversão das causas fundamentais da doença.

A profilaxia das crises é o aspecto mais importante da abordagem terapêutica dos pacientes com PAI. A identificação de pessoas portadoras na família é realizada através da quantificação de URO-S no sangue, evidenciando um bloqueio maior que $50 \%$, teste este que pode ser realizado em qualquer idade, e tem sensibilidade comprovada. Além disso, a quantificação de ALA, PBG, COPRO e URO na urina fresca também são úteis. No caso de sintomas sugestivos de PAI, havendo a necessidade de 
submeter-se o paciente a uma intervenção cirúrgica, com anestesia, é recomendável que os testes sejam repetidos, mesmo se à primeira vista foram normais. Fatores na anamnese familiar que podem sugerir crises de PAl são: reações adversas a drogas como sulfas, barbitúricos, pinturas ou solventes; convulsões, afecções psiquiátricas e episódios de confusão mental. Da mesma forma, é recomendável que os pacientes com PAI, ou mesmo aqueles com a doença na forma latente, evitem períodos, mesmo curtos, de jejum, inclusive em pós-operatórios ${ }^{55}$.

Em mulheres que sofram a influência do ciclo menstrual no desencadeamento das crises, o uso de análogos do hormônio liberador de hormônio luteinizante $(\mathrm{LHRH})$, como a gonadorrelina, pode ser útill ${ }^{38}$, pois suprimem a ovulação, sem serem porfirinogênicos. Há também referências ao uso de estrógenos, contraceptivos orais, e mesmo andrógenos, que, administrados ciclicamente, também podem prevenir as crises, o que, a princípio, pode parecer um paradoxo, já que anticoncepcionais orais são alguns dos medicamentos capazes de precipitar uma crise, tornando seu uso extremamente cauteloso. Recentemente, sugeriu-se que um modulador seletivo de receptores de estrógeno, raloxifeno, não metabolizado pela via do citocromo $\mathrm{P}_{450}$, possa ser de utilidade nas crises relacionadas a desencadeantes hormonais ${ }^{38}$. A técnica de estimulação nervosa transcutânea de baixa freqüência apresentou resultados satisfatórios quando empregada em mulheres com crises de PAI relacionadas ao período prémenstrual, reduzindo a severidade das crises e a excreção de porfirinas na urina. O mecanismo ainda é desconhecido, porém sabe-se que a 
estimulação nervosa transcutânea eleva os níveis de endorfina cerebral, de ACTH e cortisol, além de causar vasodilatação da microcirculação cutânea, hepática e esplâncnica, possivelmente interferindo na síntese de heme no fígado $^{88}$.

A escolha da medicação anti-epiléptica a ser utilizada, seja na crise de porfiria ou no período intercrítico em pacientes epilépticos, é talvez um dos maiores problemas, pela limitação ao uso de um grande número de drogas habitualmente muito eficazes. MAGNUSSEN et al. ${ }^{111}$ observaram o efeito de quatro drogas (fenobarbital, difenilhidantoína, primidona e carbamazepina) na indução hepática da ALA-S em ratos, e concluíram que a última é a menos deletéria; porém, a atividade indutora de todas elas é suficientemente importante para que seu uso seja desencorajado. Estes autores sugerem o uso de brometos no controle das crises convulsivas, mas pode-se também optar com relativa segurança pelo uso de lorazepan, paraldeído, vigabatrina e gabapentina.

Os indivíduos portadores de porfiria devem estar cientes e bem orientados quanto ao uso de drogas. De modo geral, qualquer tipo de preparação medicamentosa que combine vários tipos de drogas deve ser evitada, pois não são ainda bem conhecidas as interações farmacológicas nesta doença.

O tratamento sintomático consiste no alívio das dores abdominais, geralmente com clorpromazina ou outros fenotiazínicos, que atuam provavelmente através da inibição da atividade autonômica. Estes medicamentos são eficientes também no combate à ansiedade, às náuseas 
e vômitos. O quadro álgico também é efetivamente combatido com o uso de narcóticos como codeína, meperidina ou morfina. A hiperatividade adrenérgica é controlada com bloqueadores beta-adrenérgicos. O uso destas drogas, ou ainda de lorazepan e hidrato de cloral, pode ser útil no tratamento da ansiedade e da insônia. A lactulose e a neostigmina podem ser usadas nos casos de obstipação mais severa. Obviamente, deve-se estar atento ao fato de que algumas medicações são absolutamente contraindicadas em pacientes com PAI, e evitar o uso de medicações cujos efeitos ainda não estejam bem definidos. Outros aspectos fundamentais são o tratamento de quadros infecciosos e a manutenção do equilíbrio hidroeletrolítico, dada a importância que a hiponatremia pode assumir na gravidade das crises de PAI.

As terapias específicas para a crise de PAI são restritas ao aumento da ingestão ou à administração parenteral de carboidratos; à administração de hematina ou de heme-arginato, e de substâncias quelantes de metais, como o ácido etilenodiamino tetraacético (EDTA).

O tratamento com alta quantidade de carboidratos, como glicose, glicerol ou levulose, reduz a síntese de porfirinas, o que é conhecido como "efeito glicose". O mecanismo pelo qual isto ocorre pode ser explicado da seguinte forma: O efeito benéfico ocorreria pela repressão da ALA-S mediada pela glicose, que levaria à diminuição da excreção da ALA e do PBG durante a terapia. Quando há deficiência de heme, há inibição da enzima triptofano pirrolase, e conseqüentemente, da ruptura de triptofano. Os níveis elevados de triptofano no tecido hepático inibem a ação da 
fosfoenolpiruvato-carboquinase, com conseqüente efeito sobre a gluconeogênese, diminuindo a produção de glicose a partir de glicogênio. A resposta clínica a este tipo de terapia é extremamente variável, porém há suspeitas de que a ingestão progressivamente maior de carboidratos leve um maior número de pacientes a apresentarem bons resultados a este tratamento $^{189}$, por isto estes autores sugerem uma dieta que contenha de 450 a 500 gramas ao dia de carboidratos.

Recomenda-se o uso da hematina em casos que não responderam à remoção dos fatores precipitantes e à administração de glicose, especialmente quando existem indicações de progressão do quadro neurológico. A função da hematina, administrada por via endovenosa na dose de 3-4 mg/kg/dia, em 30 minutos, é a de repor o produto final da via produtora de heme, cuja síntese está reduzida, levando ao aumento do contingente de heme livre intracelular, auxiliando a recuperação da função celular fisiológica, especialmente se administrada em fases iniciais do ataque. Secundariamente, também reduz a produção excessiva de porfirinas e seus precursores em aproximadamente $50 \%$, temporariamente ${ }^{119,}{ }^{199}$, por exercer ação repressora sobre a ALA-S, pois a hematina atravessa facilmente a membrana mitocondrial. Os níveis de aminolevulinato declinam mais rapidamente que os de $\mathrm{PBG}^{23} . \mathrm{BOSCH}$ et al. ${ }^{25}$ relataram melhora significativa quando do uso de hematina numa paciente com quadro severo de tetraparesia, ainda que ela tenha sido administrada seis dias após o início da fraqueza. MARCHIORI et al. ${ }^{112}$ relatam caso em que a hematina foi administrada tardiamente, devido à ausência de melhora do quadro com o 
uso de glicose e bloqueadores $\beta$-adrenérgicos, e no qual observou-se redução nos níveis dos precursores ALA e PBG e melhora clínica consistente a partir do $8^{-}$dia do término do tratamento, embora durante a infusão da hematina tivessem sido notadas melhoras discretas, porém transitórias, que não persistiam até a infusão seguinte, sustentando a teoria que preconiza a sua administração em fases precoces do surto. A resposta clínica à hematina pode não ser observada até 48 horas após sua administração. McCOLL et al. ${ }^{119}$ concluíram que o resultado bioquímico é mais otimista que o clínico, pois apenas metade dos seus pacientes melhoraram, e em vários destes a melhora foi apenas temporária. Estes autores afirmam ainda que a PAl é doença de regressão espontânea, e por isto não foi possível atribuir-se a melhora clínica ao uso da hematina. Embora inicialmente ocorra repressão da produção de ALA-S, os níveis desta enzima sofrem efeito rebote, observando-se oscilações que duram até dois dias após a administração de um único pulso de hematina, sugerindo que talvez o mecanismo de controle por retro-alimentação da ALA-S possa sofrer influência de um "relógio biológico". Alguns efeitos colaterais foram relatados com o uso endovenoso da hematina: episódios febris autolimitados, coagulopatias com sangramentos, flebite ${ }^{38,}{ }^{119}$ e insuficiência renal $^{44}$. Esta última, caracterizada por necrose tubular aguda, foi descrita em uma paciente que havia recebido dose excessiva de hematina (1000 mg), e que posteriormente recobrou totalmente sua função renal normal. Neste casos, provavelmente a insuficiência renal decorreu da presença de hematina livre na circulação, formada pela rápida administração de volume 
excessivo desta substância, pois o heme, endógeno ou aquele administrado exogenamente, liga-se rapidamente a uma $\beta$-globulina, a hemopexina, que porém tem capacidade para ligar-se apenas a uma quantidade limitada de heme $(0,6 \mathrm{mg} / 100 \mathrm{ml})$. A hematina é capaz de induzir a heme-oxigenase, fato que torna-se importante quando é administrada repetidamente, o que pode teoricamente reduzir sua eficácia.

O heme arginato é um composto de utilização mais recente que a hematina, e possui as mesmas vantagens desta, sem efeitos colaterais como a possibilidade de flebite e de coagulopatias. É administrado por via endovenosa na dose de 3mg/kg, diluído em $100 \mathrm{ml}$ de solução salina, em 15 minutos. MUSTAJOKI e NORDMANN ${ }^{133}$ estudaram 51 pacientes tratados consecutivamente com heme arginato, em fase precoce (até um dia após a hospitalização), e concluíram que o prognóstico dos pacientes durante a crise foi melhor que o de qualquer outra série publicada na literatura, embora não tenha havido grupo controle neste estudo. Observou-se, porém, que o heme arginato rapidamente perde seu efeito supressor da hiperprodução de precursores, provavelmente também pela indução da heme-oxigenase. Estudos demonstraram que a administração de protoporfirina-"tin", ou mesoporfirina-"tin", a qual inibe a ruptura do heme pela heme-oxigenase, pode manter a supressão da produção excessiva dos precursores das porfirinas por um período mais longo ${ }^{62}$, além da possibilidade de poder ser administrada por via intramuscular, tornando esta uma possibilidade terapêutica promissora, porém atualmente ainda pouco utilizada. Considerase também a possibilidade de sua utilização como profilaxia das crises, pelo 
seu efeito duradouro. Fotossensibilidade cutânea é um efeito colateral importante, que pode persistir por algumas semanas, com o uso de protoporfirina "tin", além de possível toxicidade da mesma, que está sendo mais adequadamente investigada.

PETERS et al. ${ }^{144}$ relatam boa resposta, freqüentemente imediata, ao tratamento com EDTA, mesmo nos casos mais severos de porfiria. O mecanismo de ação deste quelante de metal seria a remoção do excesso de zinco, permitindo a restituição à normalidade dos complexos das porfirinas ligadas ao zinco.

A administração de antioxidantes, como as vitaminas $E$ e $Q$, ácido ascórbico, $\beta$-caroteno e selênio, não se mostrou benéfica no tratamento das crises de PAI, o que pode ser devido à sua biodisponibilidade restrita em locais particularmente afetados, ou às doses empregadas ${ }^{183}$. 
2. OBJETIVOS 
1. Descrição dos dados demográficos de pacientes com porfiria aguda intermitente.

2. Caracterização clínica das formas agudas de PAI.

3. Estudar a freqüência de crises com a tríade dor abdominal, manifestações neurológicas e psiquiátricas.

4. Determinar as características da neuropatia periférica e sua importância para o diagnóstico de PAI.

5. Caracterização clínica das formas crônicas de PAI. 
3. CASUÍSTICA E MÉTODO 
O trabalho foi retrospectivo, com análise dos dados de prontuários de 37 pacientes internados no Hospital das Clínicas da Faculdade de Medicina da Universidade de São Paulo, no período de janeiro de 1979 a dezembro de 1999, com diagnóstico de PAI, firmado pelo quadro clínico compatível e pela positividade do teste de Watson-Schwartz. Foi possível a convocação e reavaliação, através de entrevista, de treze pacientes, visando a complementação de informações. A avaliação foi realizada através de protocolo pré-elaborado (ANEXO F). Dois pacientes foram avaliados prospectivamente, e 35 retrospectivamente.

Os pacientes foram estudados quanto aos dados demográficos, manifestações clínicas, agentes desencadeantes e terapêutica utilizada (ANEXO B). Foram excluídos os pacientes nos quais o diagnóstico não foi confirmado ou nos quais havia a possibilidade de outros diagnósticos diferenciais.

As manifestações foram classificadas em agudas e crônicas, sendo considerados crônicos aqueles sinais e sintomas freqüentemente recorrentes, em intervalos relativamente curtos, às vezes mensais (ANEXO C), e que não levaram o paciente a procurar assistência médica, ao contrário das agudas. Estas manifestações foram atribuídas às alterações fisiopatológicas observadas na porfiria, e eventualmente relacionadas a um fator precipitante conhecido.

Foram analisadas as características de 63 crises agudas (ANEXO B). Do total de doentes, $13(35,1 \%)$ apresentaram, além de surtos agudos, quadro clínico também com padrão crônico. 
O quadro foi caracterizado como a) leve: quando as manifestações foram restritas à dor abdominal, alteração da cor da urina, alterações do padrão de sono ou do humor, associadas ou não entre si; b) moderado: na presença de manifestações motoras ou crises convulsivas; c) grave: quando ocorreram insuficiência ventilatória, alterações autonômicas importantes, ou alteração do nível de consciência.

Os exames relacionados ao diagnóstico da doença foram a determinação quali e quantitativa do porfobilinogênio, sendo a primeira através do teste de Watson-Schwartz, positivo em todos os pacientes, e a dosagem de ALA e de porfirinas na urina. O método utilizado no laboratório do Hospital das Clínicas consiste em adicionar o reagente aldeído de Ehrlich em quantidade igual à da amostra de urina fresca obtida, e realizar a extração desta solução com butanol, demonstrando a permanência do pigmento vermelho na camada aquosa inferior. A determinação quantitativa do ácido $\delta$-aminolevulínico na urina foi realizada em quinze pacientes, em outros laboratórios, e o resultado foi obtido em seis destes pacientes. A dosagem quantitativa do porfobilinogênio urinário foi efetuada em dez doentes, no laboratório do Instituto de Farmácia da Universidade de São Paulo e em outros laboratórios externos ao Hospital das Clínicas, sendo que apenas três destes resultados estavam disponíveis. Foram realizadas ainda a dosagem de porfirinas urinárias em trinta e dois doentes, e obtidos os resultados de dez destes pacientes.

O exame eletroneuromiográfico foi realizado em seis pacientes durante as crises nas quais houve acometimento do sistema nervoso 
periférico, porém apenas três destes resultados puderam ser recuperados. Dois foram realizados no Serviço de Eletroneuromiografia do Departamento de Neurologia do Hospital das Clínicas, e os demais em outros locais. O estudo anátomo-patológico foi feito em três pacientes, sendo em um paciente por biópsia de nervo sural, em outro por biópsia de músculo, e no último por necrópsia. Outros dados laboratoriais investigados foram o sódio sérico, o líquor, e exames radiológicos: tomografia computadorizada e ressonância magnética de encéfalo.

O tratamento empregado nas crises e a evolução clínica também foram descritos. Os dados coletados foram analisados e comparados com a literatura, em relação às características do grupo estudado, número e tipo de fatores predisponentes das crises, caracterização do quadro clínico e exames complementares realizados.

Adicionalmente, foi calculado o risco relativo, ou "odds ratio" para verificar se havia correlação entre o número de fatores precipitantes identificados e o desenvolvimento de neuropatia periférica ao longo da evolução da crise de PAI. 
4. RESULTADOS 


\subsection{CARACTERÍSTICAS DO GRUPO ESTUDADO}

A distribuição da amostra obtida de pacientes em relação ao sexo foi de 27 mulheres para 10 homens. As pacientes do sexo feminino apresentaram 50 crises, e os do masculino, 13. Analisando-se as crises de caráter crônico, notamos que a proporção entre mulheres e homens é de $5,5: 1$

A idade do primeiro ataque de PAI no grupo estudado variou de 6 a 48 anos, observando-se uma média de 27,1 anos, e mediana de 24 anos, considerando-se ambos os sexos conjuntamente. Nos homens, a idade mínima da crise inaugural foi de 6 anos, e a máxima de 48 anos, com média de 29,2 anos, e mediana de 29 anos. No sexo feminino, a idade de início mais precoce foi de 18 anos, e a mais tardia 42 anos. A média foi 26,2 anos, e a mediana 23 anos.

Considerando que vários pacientes apresentaram mais de uma crise no período estudado, a idade onde concentrou-se a maior incidência de crises nestes pacientes foi a de 24 anos, e a média, 26,9 anos, excetuandose aquelas de caráter crônico.

Vinte e um pacientes relataram casos comprovados de PAI na família, enquanto em 10 não havia antecedente familiar conhecido, e em seis este dado não foi obtido. O número de parentes acometidos por paciente é o seguinte: um parente: nove pacientes; dois parentes: nove pacientes; três: dois pacientes, e seis: um paciente. 


\subsection{Manifestações Clínicas}

\subsubsection{SinAIS E SinTOMAS}

Manifestações clínicas nas crises de PAl ( $n=63$ crises)

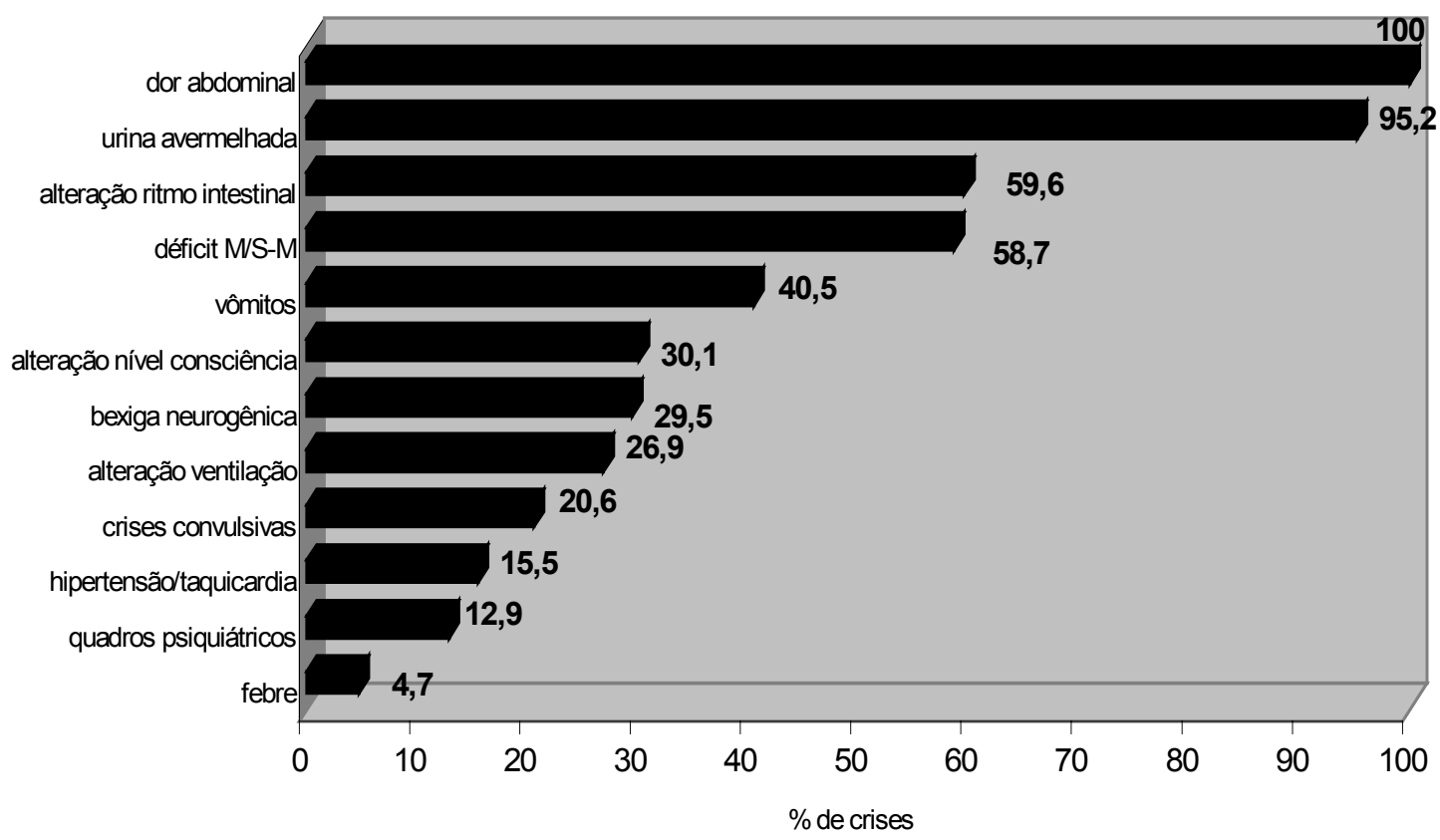

Figura 2- Freqüência das manifestações clínicas durante as crises de PAl. As porcentagens das alterações intestinais e dos quadros psiquiátricos foram calculadas em relação a 62 crises, já que este dado não foi obtido em um surto em cada um destes parâmetros

$\mathrm{Na}$ série aqui estudada, os dados clínicos mais freqüentemente

observados nas 63 crises, em ordem decrescente, foram: dor abdominal, alteração da cor da urina, alteração do ritmo intestinal, déficits motores ou sensitivo-motores, vômitos, rebaixamento do nível de consciência ou confusão mental, bexiga neurogênica, alterações ventilatórias, crises convulsivas, taquicardia e/ou hipertensão arterial sistêmica, manifestações psiquiátricas e, por último, febre não relacionada a processo infeccioso (Figura 2). 


\section{TABELA 1- NÚMERO DE CRISES COM ACOMETIMENTO DO SISTEMA NERVOSO PERIFÉRICO (SNP) E/OU CENTRAL (SNC)}

\begin{tabular}{c|c|c|c|c}
\hline \hline Tipo de acometimento & SNP* $^{*}$ & SNC $^{* *}$ & $\begin{array}{c}\text { SNP e } \\
\text { SNC }\end{array}$ & $\begin{array}{c}\text { Outras } \\
\text { alterações } \\
* * *\end{array}$ \\
\hline Número de crises & 16 & 7 & 22 & 18 \\
\hline
\end{tabular}

* Déficit motor e/ou sensitivo, isoladamente ou com outras alterações

** Alteração do nível de consciência e/ou crises convulsivas e/ou quadro psiquiátrico, isoladamente ou com outras alterações

*** Dor abdominal e/ou urina vermelha e/ou alteração do ritmo intestinal, sem comprometimento do SNC ou SNP

O sistema nervoso periférico (déficits motores e/ou sensitivos) foi acometido de maneira isolada em $25,3 \%$ das crises, e o sistema nervoso central (alteração de nível de consciência e/ou crises convulsivas e/ou quadro psiquiátrico), em $11,1 \%$ dos ataques, sendo que em 22 crises houve acometimento tanto do SNP quanto do SNC (Tabela 1).

Observa-se que $100 \%$ dos pacientes apresentaram dor abdominal como manifestação da crise porfírica. Em quase todas as crises de caráter crônico a dor abdominal esteve presente. Apenas em uma paciente deste grupo ela esteve ocasionalmente ausente. Em 61 das 63 crises a dor abdominal foi a primeira manifestação; em uma delas este dado não foi obtido, e apenas em uma crise a manifestação inicial foi vômito. 


\section{Característica da dor abdominal e/ou} lombar

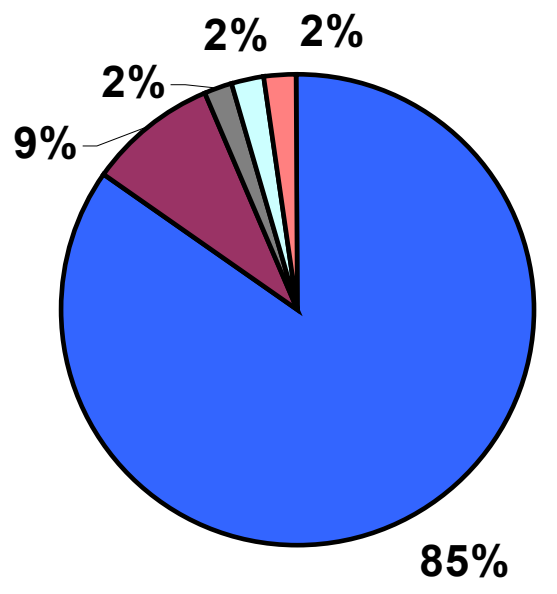

$\square$ cólica $\square$ pontada $\square$ indefinido $\square$ misto $\square$ peso

Figura 3 - Tipo de dor nos 45 surtos de PAI nos quais este caráter pôde ser identificado

Em 28,5\% das crises não houve informação a respeito do caráter do quadro álgico. Nas demais, observa-se nítida predominância de dor do tipo cólica, seguida de dor em pontada, e depois de porcentagens iguais com característica de peso, padrão misto (em cólica e pontada), e não definido pelo paciente (Figura 3). 


\title{
Localização da dor abdominal e/ou lombar
}

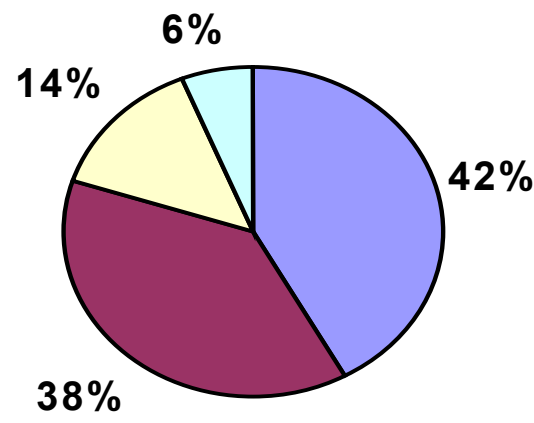

\author{
$\square$ difusa \\ 口localizada: hipocôndrio/hipogástrio/flanco/baixo ventre \\ $\square$ abdominal e lombar \\ 口lombar
}

Figura 4 - Sítio da dor em 49 crises nas quais foi identificado

Na maioria das crises a dor apresentou-se como difusa pelo abdome, seguida da dor localizada em algum ponto da região abdominal, dos quais os mais freqüentes foram baixo ventre e hipocôndrio (Figura 4). Em 22,2\% das crises este dado não foi informado. Observa-se que em $14,2 \%$ das crises houve associação de dor abdominal e lombar, e que em 6,1\% a apresentação álgica foi puramente lombar. 


\section{Duração da dor abdominal elou lombar}

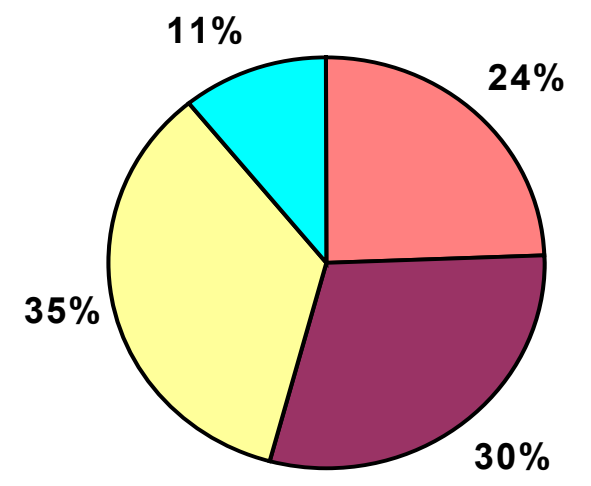

Figura 5 - Tempo de evolução da dor em 36 crises

Em 43,0\% das crises não houve informação a respeito da duração da dor abdominal, do início do quadro até a hospitalização ou consulta. Das demais, a maioria tem evolução sub-aguda, entre quatro a oito semanas de duração, seguida de quadros mais recentes, de até um mês (Figura 5)

\section{TABELA 2- ALTERAÇÃO DO RITMO INTESTINAL}

\begin{tabular}{c|c|c|c}
\hline \hline Tipo de alteração & Obstipação & Diarréia & Sem alteração \\
\hline \multicolumn{1}{c|}{ Sexo e número de crises } & & & \\
\hline Ambos os sexos $\left(n=62^{*}\right)$ & $51,6 \%$ & $9,7 \%$ & $40,3 \% \%^{* *}$ \\
Sexo feminino $(n=49)$ & $57,1 \%$ & $8,1 \%$ & $36,7 \%{ }^{* *}$ \\
Sexo masculino $(n=13)$ & $30,7 \%$ & $15,3 \%$ & $53,8 \%$ \\
\hline \hline
\end{tabular}

Valores em porcentagem do número de crises

* em um paciente este dado não foi obtido

** em uma paciente do sexo feminino ocorreu obstipação alternada com diarréia

Dentre as demais manifestações abdominais, encontramos as alterações do ritmo intestinal, presente em 59,6\% de 62 crises, pois em uma das crises este dado não pôde ser obtido. Avaliando-se as crises nas quais 
elas estiveram presentes, observamos que a obstipação foi relatada muito mais freqüentemente $(84,2 \%)$ que a diarréia $(15,8 \%)$, e foi praticamente concomitante com o quadro doloroso em todos os casos. Em 51,6\% das 62 crises avaliadas a obstipação esteve presente, quando considerados ambos os sexos. Observa-se obstipação intestinal em $57,1 \%$ das crises no sexo feminino, enquanto em apenas $30,7 \%$ das crises no sexo masculino. Diarréia manifestou-se em $9,7 \%$ de todas as crises, em $8,1 \%$ das crises no sexo feminino, e em 15,3\% das crises no sexo masculino. Em 40,3\% das crises não houve alteração do ritmo intestinal, observando-se o mesmo em $36,7 \%$ das crises no sexo feminino, e em $53,8 \%$ das crises no sexo masculino (Tabela 2).

\section{TABELA 3- ALTERAÇÃO QUALITATIVA DA COR DA URINA}

\begin{tabular}{l|c|c}
\hline \hline Tipo de alteração & Urina avermelhada & Sem alteração \\
\hline Sexo e número de crises & & \\
\hline Ambos $(n=63)$ & $95,2 \%$ & $4,8 \%$ \\
Sexo feminino $(n=50)$ & $96,0 \%$ & $4,0 \%$ \\
Sexo masculino $(n=13)$ & $92,3 \%$ & $7,7 \%$ \\
\hline \hline
\end{tabular}

Valores em porcentagem do número de crises

A alteração da cor da urina, descrita na maioria dos casos como avermelhada, é uma das manifestações mais constantes nas crises de porfiria dos pacientes aqui avaliados, presente em $95,2 \%$ do total de crises. No sexo feminino, foi verificada em $96,0 \%$ das crises, e no sexo masculino, em $92,3 \%$ dos surtos (Tabela 3). Este sinal foi observado em apenas $30,7 \%$ dos pacientes com quadros crônicos. 


\section{TABELA 4- ALTERAÇÃO DO NÍVEL DE CONSCIÊNCIA OU CONFUSÃO MENTAL}

\begin{tabular}{l|c|c}
\hline \hline Tipo de alteração & Com alteração & Sem alteração \\
\hline Sexo e número de crises & & \\
\hline Ambos $(n=63)$ & $30,1 \%$ & $69,9 \%$ \\
Sexo feminino $(n=50)$ & $30,0 \%$ & $70,0 \%$ \\
Sexo masculino $(n=13)$ & $30,7 \%$ & $69,3 \%$ \\
\hline
\end{tabular}

Valores em porcentagem do número de crises

$\mathrm{Na}$ maioria das crises $(69,9 \%)$ não houve alteração do nível de consciência ou confusão mental. $30,0 \%$ das crises do sexo feminino e $30,7 \%$ das do sexo masculino apresentaram-se com alteração da consciência, com ou sem déficit de atenção, em algum momento da evolução do surto (Tabela 4).

TABELA 5- CRISES CONVULSIVAS

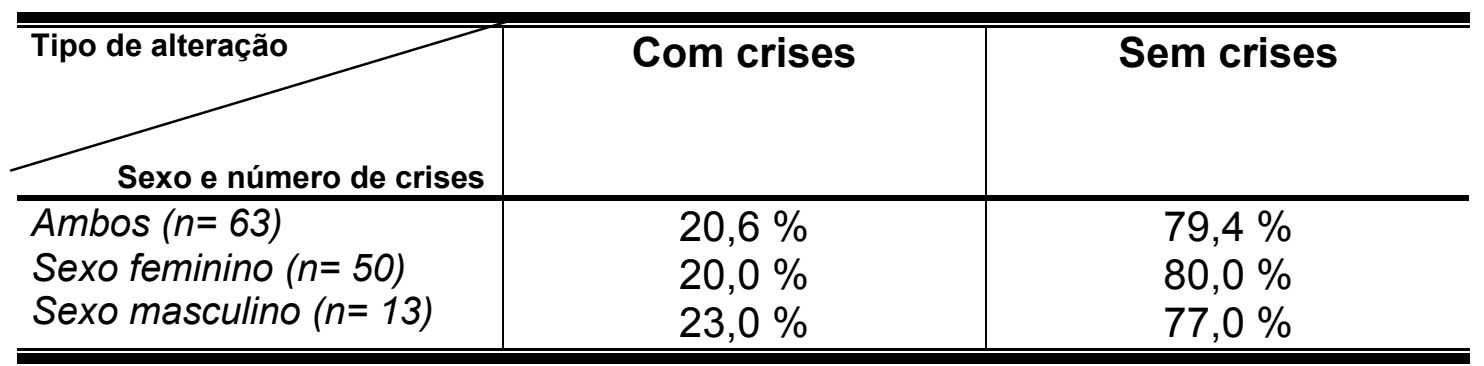

Valores em porcentagem do número de crises

Crises convulsivas foram observadas em $20,6 \%$ das 63 crises avaliadas, constatando-se que dentre as 50 crises do sexo feminino, $20,0 \%$, e, entre as 13 do sexo masculino, 23,0\%, apresentaram este quadro (Tabela $5)$. 


\section{TABELA 6- MANIFESTAÇÕES PSIQUIÁTRICAS}

\begin{tabular}{c|c|c}
\hline \hline Tipo de alteração & Com manifestações & Sem manifestações \\
\hline Sexo e número de crises & & \\
\hline Ambos $\left(n=62^{*}\right)$ & $12,9 \%$ & $87,1 \%$ \\
Sexo feminino $(n=49)$ & $10,2 \%$ & $89,8 \%$ \\
Sexo masculino $(n=13)$ & $23,0 \%$ & $77,0 \%$ \\
\hline \hline
\end{tabular}

Valores em porcentagem sobre o número de crises

* este dado não foi obtido em um paciente

Em relação ao quadro psiquiátrico, em uma das 63 crises este dado não foi obtido, e, das demais 62 crises avaliadas, em 12,9\% foi observada a presença de manifestações psiquiátricas. No sexo feminino, estas estiveram presentes em $10,2 \%$ das crises, enquanto no sexo masculino, em $23,0 \%$ dos episódios (Tabela 6).

Insônia foi um sintoma relatado por alguns pacientes, descrito em nove das 63 crises, todas em pacientes do sexo feminino. Dos 13 pacientes com apresentação dos sintomas de forma crônica, uma paciente relatou insônia como parte do quadro de porfiria, e outra episódios depressivos recorrentes.

\section{TABELA 7- NEUROPATIA MOTORA OU SENSITIVO-MOTORA}

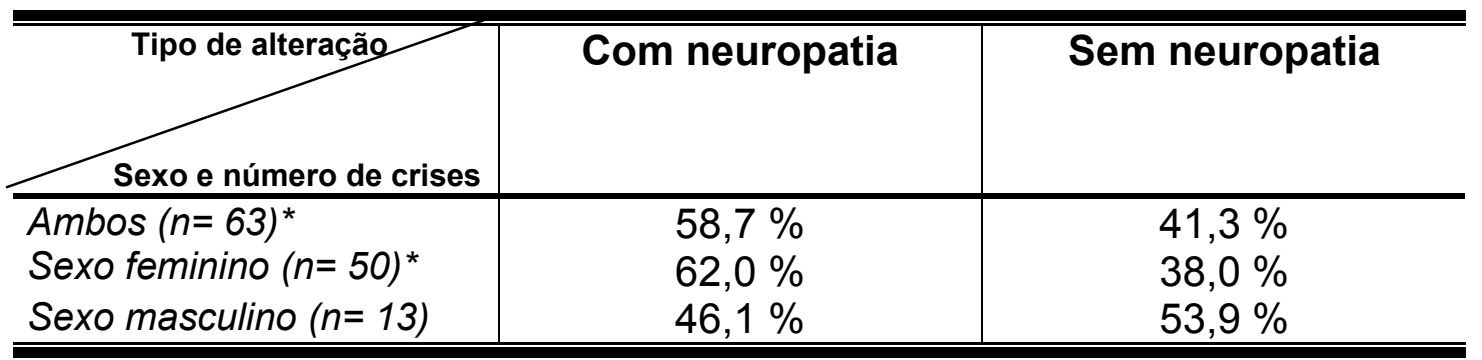

Valores em porcentagem sobre o número de crises

* Não foi incluído neste cálculo crise na qual ocorreram apenas parestesias 
Paresia ou paralisia de membros, acompanhada ou não de déficits sensitivos, esteve presente em $58,7 \%$ das crises (ou em $72,9 \%$ dos pacientes) nesta série, observando-se que no sexo feminino este quadro manifestou-se em $62,0 \%$ dos episódios, e no masculino em 46,1\% (Tabela 7). Em um paciente o quadro foi puramente sensitivo, na forma de parestesias, sem comprovação objetiva de déficit sensitivo. Em 17,1\% das crises com neuropatia periférica o acometimento foi apenas motor, enquanto em $32,8 \%$ foi sensitivo-motor. Em $6,2 \%$ o padrão do déficit não foi adequadamente caracterizado quanto ao tipo de acometimento. Em 98,5\% dos casos a paresia e/ou o acometimento sensitivo, incluindo o quadro puramente disestésico, foram observados nos quatro membros, enquanto apenas um paciente apresentou fraqueza em um dos membros superiores, caracterizada clinicamente como neuropatia sensitivo-motora do radial, unilateral. Em todos os casos nos quais a neuropatia periférica sensitivomotora ou motora esteve presente, ela manifestou-se após a dor abdominal, instalando-se de modo agudo em todas as vezes.

A proporção de pacientes com neuropatia periférica motora ou sensitivo-motora foi maior em pacientes que só apresentaram formas agudas da doença $(87 \%)$ do que nos que tiveram também manifestações crônicas (53\%).

$18,5 \%$ dos pacientes com neuropatia periférica motora ou sensitivomotora evoluíram com atrofia muscular. 
TABELA 8- TOPOGRAFIA DO DÉFICIT MOTOR PREDOMINANTE

\begin{tabular}{l|c|c|c|c|c|c}
\hline \hline & $\begin{array}{c}\text { Proximal } \\
\text { MMSS e } \\
\text { MMII }\end{array}$ & $\begin{array}{c}\text { Distal } \\
\text { MMSS e } \\
\text { MMII }\end{array}$ & $\begin{array}{c}\text { Proximal } \\
\text { MMII e } \\
\text { distal } \\
\text { MMSS }\end{array}$ & $\begin{array}{c}\text { Proximal } \\
\text { MMSS e } \\
\text { distal } \\
\text { MMII }\end{array}$ & $\begin{array}{c}\text { Não } \\
\text { obtido }\end{array}$ & TOTAL* $^{\text {MMStido }}$ \\
\hline $\begin{array}{l}\text { Número } \\
\text { de Crises }\end{array}$ & 13 & 7 & 1 & 1 & 14 & 36 \\
\hline
\end{tabular}

${ }^{*}$ Entre 37 crises com déficit motor, 1 corresponde a acometimento isolado do nervo radial MMSS- membros superiores MMII- membros inferiores

A intensidade da paresia foi maior na musculatura proximal em $36,1 \%$ dos casos, e distal em 19,4\%. Em 38,8\% destas crises a distribuição do déficit motor não foi obtida (Tabela 8).

Em $12,7 \%$ das 63 crises (ou em $21 \%$ das 37 crises com neuropatia periférica) foi observada paresia ou paralisia de nervos cranianos, sendo mais freqüente o acometimento dos nervos glossofaríngeo e vago (em cinco crises), seguido pelo do facial (em duas crises) e, por último, uma descrição de redução da acuidade visual, que poderia eventualmente ser atribuída ao acometimento do nervo óptico. Em todos os casos a alteração de nervos cranianos só ocorreu na presença de neuropatia motora ou sensitivo-motora, e nunca isoladamente.

Sintomas sensitivos foram relatados em $57,8 \%$ das crises com neuropatia periférica, sob a forma de parestesias, hipoestesia, e dores, com localizações variáveis. 


\section{TABELA 9- CARACTERÍSTICAS DAS MANIFESTAÇÕES SENSITIVAS}

\begin{tabular}{l|l|c}
\hline \multicolumn{1}{c|}{ Tipo de alteração sensitiva } & Localização & $\begin{array}{c}\text { Número de } \\
\text { crises }\end{array}$ \\
\hline Hipoestesia & bota e luva & 2 \\
\hline Hipoestesia & bota & 3 \\
\hline Hipoestesia & abdome & 2 \\
\hline Hipoestesia & território nervo radial & 1 \\
\hline Hipoestesia & difusa 4 membros & 1 \\
\hline Hipoestesia & $\begin{array}{l}\text { face anterior tórax T2 } \\
\text { a T5 }\end{array}$ & 1 \\
\hline Dores & difusas & 1 \\
\hline Parestesias & bota e luva & 2 \\
\hline Parestesias & difusas 4 membros & 1 \\
\hline Parestesias & difusas MMII & 1 \\
\hline Parestesias & difusas MSE e MMII & 1 \\
\hline Parestesias & difusas & 5 \\
\hline Hipoestesia bota e luva + parestesia plantas & - & 2 \\
dos pés & - & 1 \\
\hline Hipoestesia + parestesia & bota e luva & 1 \\
\hline Hipoestesia nível T3 + parestesia bota & - & 1 \\
\hline Ataxia sensitiva & 4 membros & 4 \\
\hline Não caracterizada & - & 30 \\
\hline TOTAL* & & \\
\hline \hline
\end{tabular}

MSE- membro superior esquerdo

MMII- membros inferiores

* Alguns pacientes apresentaram várias destas manifestações sensitivas na mesma crise

Em quatro destas crises o acometimento sensitivo não foi adequadamente caracterizado, e nas demais observa-se a seguinte distribuição quanto à região: 10 crises apenas com parestesias, sendo sete difusas, nos quatro membros ou no corpo todo, em uma delas com marcante predomínio proximal, duas em bota e luva, e uma apenas nos membros inferiores; uma crise com dores difusas; 14 crises com hipoestesia, das quais quatro apresentam-se junto com parestesias. Em quatro crises o acometimento sensitivo foi observado na região torácica e/ou abdominal, sendo em uma delas suspenso, em outra na forma de nível sensitivo, e nas 
demais, no abdome, não tendo sida obtida informação mais detalhada sobre a localização (Tabela 9). Em uma crise havia alteração apenas da sensibilidade profunda, na forma de uma síndrome cordonal posterior nos quatro membros, e em outra hipoestesia no território do nervo radial.

Em 21 das 36 crises com tetraparesia houve referência à motricidade reflexa. Em três destas os reflexos bicipitais, patelares e aquileus estavam normais, em sete estavam todos abolidos, em cinco, hipoativos. Os reflexos bicipitais e patelares estiveram abolidos ou hipoativos, enquanto os aquileus estavam hipoativos ou normais, em cinco crises. Em apenas uma crise unicamente o reflexo aquileu esteve abolido, e os demais, normais. Em apenas um dos pacientes foi observado sinal de Babinski, unilateral. Nenhum dos pacientes apresentou hiperreflexia.

TABELA 10- COMPROMETIMENTO DA VENTILAÇÃO

\begin{tabular}{c|c|c}
\hline \hline Tipo de alteração & Comprometida & Não comprometida \\
\hline Sexo e número de crises & & \\
\hline Ambos $(n=63)$ & $26,9 \%$ & $73,1 \%$ \\
Sexo feminino $(n=50)$ & $26,0 \%$ & $74,0 \%$ \\
Sexo masculino $(n=13)$ & $30,7 \%$ & $69,3 \%$ \\
\hline \hline
\end{tabular}

Valores em porcentagem do número de crises

Episódios de desconforto respiratório ou de insuficiência ventilatória foram observados em $26,9 \%$ das 63 crises, sendo que, daquelas observadas no sexo feminino, $26,0 \%$, e no sexo masculino, $30,7 \%$, apresentaram alterações ventilatórias (Tabela 10), necessitando de entubação orotraqueal. 
A tríade clássica dor abdominal, quadro psiquiátrico e neurológico foi observada em $9,5 \%$ dos surtos, e apenas em um paciente estas manifestações apresentaram-se concomitantemente.

Um paciente apresentou durante a evolução amaurose cortical, tendo sido descartadas afecções oculares ou do nervo óptico.

Em 4,7\% das crises ocorreu febre não atribuída a quadro infeccioso, apesar de investigação adequada, e que poderia ser atribuída à própria crise de porfiria. Foi observada febre em um número maior de crises, porém em alguns destes casos foram identificados focos infecciosos, de fontes hospitalares ou não, e conseqüentemente não pudemos afirmar que a elevação da temperatura deveu-se exclusivamente à porfiria.

Caquexia foi observada em três das 63 crises, todas em pacientes do sexo feminino, e sempre acompanhando episódios com vômitos intensos e inapetência.

Hiponatremia foi observada em $14,0 \%$ das crises, encontrando-se também esporadicamente outros distúrbios metabólicos, como hipocalemia e hipocalcemia. O nível natrêmico mais baixo observado foi de $101 \mathrm{mEq} / \mathrm{l}$, o de potássio, de 2,9 mEq/l, e a hipocalcemia manifestou-se através de tetania e cãimbras em uma paciente, quadro este que foi revertido com a administração de cálcio. 


\subsubsection{NÚMERO E INTENSIDADE DAS CRISES}

\section{Número de pacientes $\mathrm{x}$ número de crises}

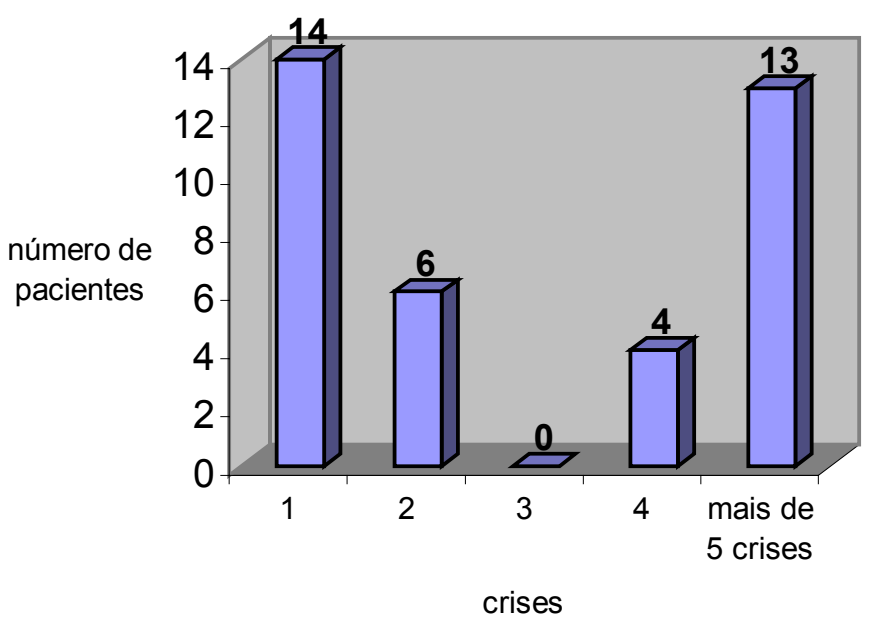

Figura 6 - Número de pacientes por número de crises. Os pacientes com formas crônicas foram incluídos como mais de 5 crises.

$37,8 \%$ dos pacientes apresentaram crise única, $16,2 \%$, duas crises; $10,8 \%$, quatro crises; e $35,1 \%$, mais de cinco crises, correspondendo este último grupo aos casos com manifestações crônicas (Figura 6).



Figura 7- Número de pacientes do sexo feminino por número de crises 


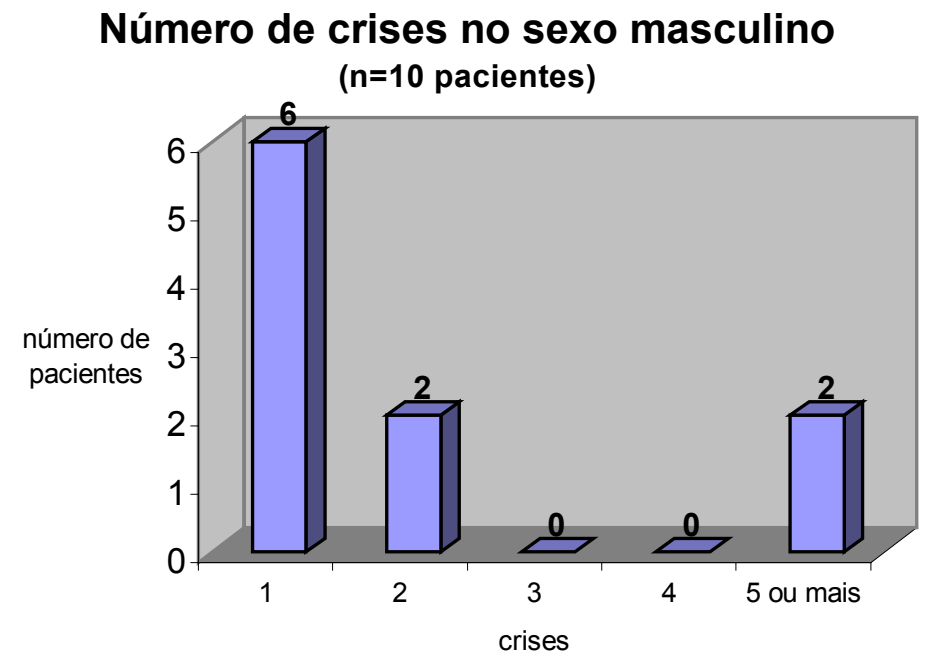

Figura 8 - Número de pacientes do sexo masculino por número de crises

Separando-se os pacientes segundo o sexo, observamos que entre as 27 mulheres $29,6 \%$ apresentaram uma única crise, $14,8 \%$ duas crises, outros $14,8 \%$ quatro crises, e $40,7 \%$, quadros crônicos no período estudado (Figura 7). Dentre 10 homens, 60\% tiveram uma crise, 20\% duas crises, e o mesmo montante formas crônicas (Figura 8).

\section{Distribuição das crises quanto à gravidade \\ $(n=63$ crises $)$}

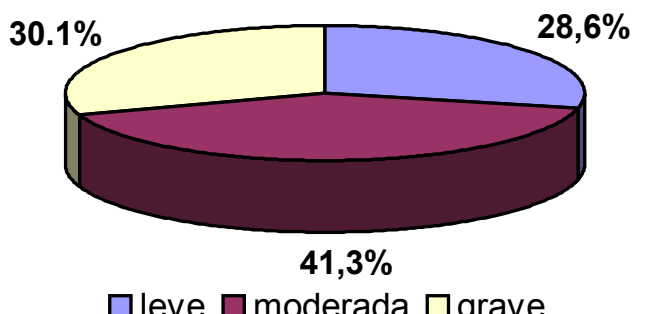

Figura 9 - Classificação das formas agudas de PAl segundo a gravidade 
Do total de 63 crises agudas, bem definidas clinicamente, e excluindose os episódios considerados como crônicos, $28,6 \%$ das crises foram classificadas como leves, $41,3 \%$ como moderadas, e $30,1 \%$ como graves (Figura 9).

No sexo feminino, de um total de 50 crises avaliadas, $28 \%$ foram consideradas leves, $42 \%$ moderadas, e $30 \%$ graves. Entre 13 crises no sexo masculino, $30,7 \%$ foram leves, $38,5 \%$ moderadas, e $30,7 \%$ graves.

Treze pacientes apresentaram inumeráveis crises, de leve intensidade, além das agudas já descritas, geralmente percebidas quando avaliadas retrospectivamente, caracterizadas por dores abdominais acompanhadas ou não de alteração da cor da urina. Em uma paciente ocorreram manifestações psiquiátricas, caracterizadas como quadro depressivo acompanhado eventualmente de dor abdominal, que regrediam espontaneamente e não levavam a paciente a procurar auxílio hospitalar. Nos pacientes com formas crônicas, nota-se que os sintomas apresentados nestas crises mais leves seguiram o mesmo padrão num mesmo paciente, em crises diferentes. Todos os quadros classificados como crônicos enquadram-se na categoria das leves.

Entre os 13 pacientes com este padrão de recorrência, foram relatados 20 episódios que necessitaram de internação, e mesmo nestes, nota-se que a maioria (55,0\%) ainda é de crises leves, $25,0 \%$ de moderadas, e $20,0 \%$ graves. De quatro crises desta última intensidade, três foram observadas numa mesma paciente. 


\section{Número de crises entre os pacientes com quadro grave}

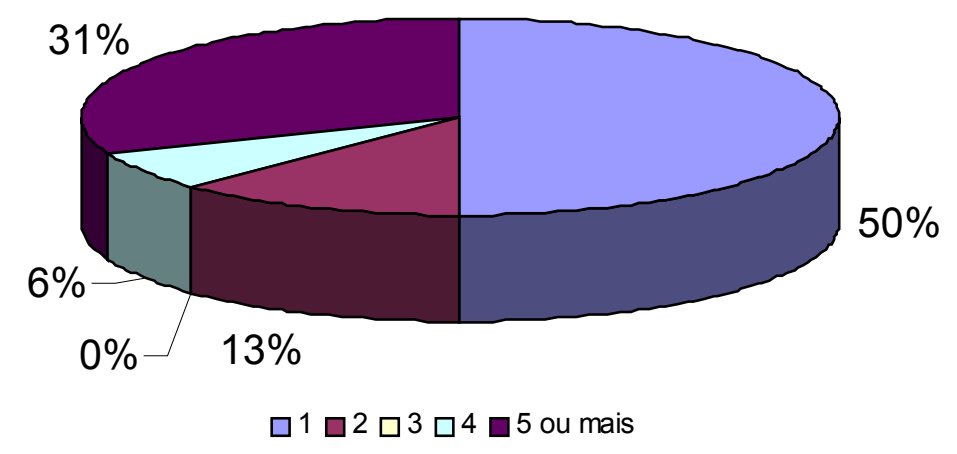

Figura 10 - Número de surtos agudos nos pacientes com quadros graves

A maioria dos pacientes com quadro grave teve número reduzido de crises, e $31 \%$ destes doentes são representados por aqueles que apresentaram também formas crônicas (Figura 10).

Nos dois sexos a $3^{\text {a }}$ década é a faixa etária onde concentram-se 0 maior número de casos graves, porém, esta é também a época na qual concentra-se o maior número de crises. 


\subsubsection{Fatores Precipitantes}

\section{TABELA 11- FATORES PRECIPITANTES}

\begin{tabular}{|c|c|c|c|c|c|}
\hline \multicolumn{2}{|c|}{ Fator Precipitante } & Sexo & $\begin{array}{c}\text { Com } \\
\text { neuropatia }\end{array}$ & $\begin{array}{c}\text { Sem } \\
\text { neuropatia }\end{array}$ & TOTAL \\
\hline \multirow{2}{*}{ Medicação } & \multirow{2}{*}{$\begin{array}{l}\text { Anticoncepcional oral } \\
\text { Outras }\end{array}$} & $\mathrm{F}$ & 3 & 1 & 4 \\
\hline & & $\begin{array}{l}\mathrm{F} \\
\mathrm{M}\end{array}$ & $\begin{array}{c}20 \\
3\end{array}$ & $\begin{array}{l}6 \\
2\end{array}$ & $\begin{array}{c}26 \\
5\end{array}$ \\
\hline \multicolumn{2}{|l|}{ Jejum } & $\begin{array}{l}\mathrm{F} \\
\mathrm{M}\end{array}$ & $\begin{array}{l}0 \\
0\end{array}$ & $\begin{array}{l}3 \\
0\end{array}$ & $\begin{array}{l}3 \\
0\end{array}$ \\
\hline \multicolumn{2}{|l|}{ Estresse } & $\begin{array}{l}F \\
M\end{array}$ & $\begin{array}{l}0 \\
0\end{array}$ & $\begin{array}{l}3 \\
0\end{array}$ & $\begin{array}{l}3 \\
0\end{array}$ \\
\hline \multicolumn{2}{|c|}{$\begin{array}{l}\text { Irregularidade menstrual, ovulação } \\
\text { ou período pré-menstrual }\end{array}$} & $F$ & 4 & 4 & 8 \\
\hline \multicolumn{2}{|l|}{ Infecção } & $\begin{array}{l}\mathrm{F} \\
\mathrm{M}\end{array}$ & $\begin{array}{l}6 \\
0\end{array}$ & $\begin{array}{l}1 \\
2\end{array}$ & $\begin{array}{l}7 \\
2\end{array}$ \\
\hline \multicolumn{2}{|c|}{$\begin{array}{l}\text { Cirurgia, procedimento com sedativo } \\
\text { ou aborto }\end{array}$} & $\begin{array}{l}\mathrm{F} \\
\mathrm{M}\end{array}$ & $\begin{array}{l}3 \\
0\end{array}$ & $\begin{array}{l}3 \\
0\end{array}$ & $\begin{array}{l}6 \\
0\end{array}$ \\
\hline \multicolumn{2}{|l|}{ Alcoolismo } & $\begin{array}{l}F \\
M\end{array}$ & $\begin{array}{l}0 \\
0\end{array}$ & $\begin{array}{l}0 \\
2\end{array}$ & $\begin{array}{l}0 \\
2\end{array}$ \\
\hline \multirow{2}{*}{\multicolumn{2}{|c|}{ Não identificado }} & $\begin{array}{l}\mathrm{F} \\
\mathrm{M}\end{array}$ & $\begin{array}{l}7 \\
4\end{array}$ & $\begin{array}{l}1 \\
1\end{array}$ & $\begin{array}{l}8 \\
5\end{array}$ \\
\hline & & $\underset{*}{\text { TOTAL }}$ & 50 & 29 & 79 \\
\hline
\end{tabular}

Número de vezes em que cada fator precipitante aparece como responsável por uma crise aguda em relação ao número total de fatores precipitantes implicados nos 37 pacientes.

* alguns pacientes relataram combinação de dois ou mais fatores precipitantes

Em 13 das 63 crises avaliadas o fator precipitante não foi identificado (Tabela 11), e das 50 crises restantes, em 25 houve identificação de um fator precipitante, e na outra metade, de dois ou mais fatores precipitantes. Os agentes foram classificados em exógenos, como as medicações, e endógenos, como o jejum, o estresse, e alterações hormonais decorrentes do ciclo menstrual. Os medicamentos foram os fatores mais freqüentemente relacionados ao desencadeamento de crises com neuropatia periférica 
motora e sensitivo-motora, enquanto jejum e estresse, fatores endógenos, estiveram associados com crises sem neuropatia periférica, já que o valor do risco relativo calculado é de 7,22.

\section{TABELA 12 - FATORES PRECIPITANTES NAS CRISES GRAVES}

\begin{tabular}{|c|c|c|c|}
\hline \multicolumn{3}{|c|}{ Fatores Precipitantes } & \multirow{2}{*}{$\begin{array}{c}\begin{array}{c}\text { Número } \\
\text { de crises }\end{array} \\
1\end{array}$} \\
\hline \multirow{8}{*}{ 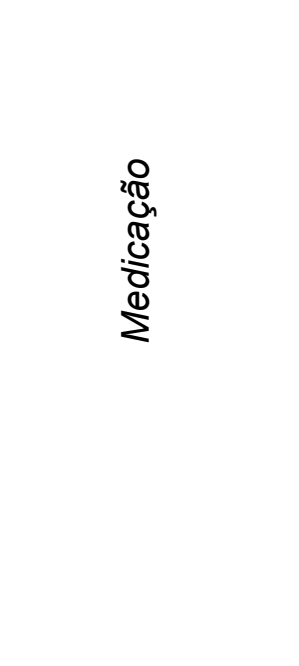 } & \multirow{2}{*}{$\begin{array}{l}\text { Medicação anti- } \\
\text { epiléptica }\end{array}$} & Isolada & \\
\hline & & $\begin{array}{l}\text { Associada a período pré- } \\
\text { menstrual }\end{array}$ & 3 \\
\hline & \multirow{2}{*}{ Butilescopolamina } & Isolada & 2 \\
\hline & & $\begin{array}{l}\text { Associada a } \\
\text { anticoncepcional oral }\end{array}$ & 2 \\
\hline & \multicolumn{2}{|c|}{ Analgésico não identificado } & 1 \\
\hline & \multirow{2}{*}{$\begin{array}{l}\text { Processo infeccioso e } \\
\text { uso de antibióticos }\end{array}$} & Isolado & 1 \\
\hline & & $\begin{array}{l}\text { Associado a procedimento } \\
\text { obstétrico }\end{array}$ & 2 \\
\hline & \multicolumn{2}{|c|}{ Medicação não identificada } & 2 \\
\hline \multicolumn{3}{|l|}{ Etilismo crônico } & 1 \\
\hline \multicolumn{3}{|l|}{ Não identificado } & 4 \\
\hline \multicolumn{3}{|l|}{ TOTAL } & 19 \\
\hline
\end{tabular}

Notamos que as medicações, acompanhadas ou não de outros fatores, são os elementos mais freqüentemente relacionados com a precipitação de episódios graves de PAI, presentes em 73,6\% dos episódios (Tabela 12). Em 42,8\% das crises nas quais as drogas são agentes desencadeantes, elas são identificadas como precipitantes isolados, e nos demais surtos, mais de uma medicação está envolvida, ou então estão 
associadas a outros possíveis desencadeantes. A associação de dois ou mais fatores é observada em $46,6 \%$ destas crises.

Analisando-se a influência do número de agentes precipitantes na gravidade da crise, calculamos que o valor do risco relativo para a ocorrência de crises graves é 12,25 , indicando que há correlação entre a ocorrência de vários fatores precipitantes e surtos desta severidade.

TABELA 13- FATORES PRECIPITANTES NAS CRISES LEVES

\begin{tabular}{|c|c|c|c|}
\hline \multicolumn{3}{|c|}{ Fatores Precipitantes } & Número \\
\hline \multirow{4}{*}{ 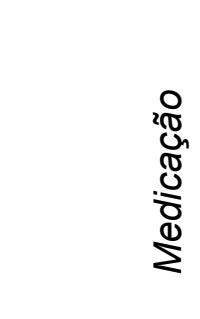 } & \multirow{2}{*}{ Butilescopolamina } & Isolada & 4 \\
\hline & & Associada a jejum e estresse & 1 \\
\hline & \multicolumn{2}{|l|}{ Anti-epiléptico } & 1 \\
\hline & \multicolumn{2}{|c|}{ Anticoncepcional oral } & 1 \\
\hline \multicolumn{3}{|c|}{ Irregularidade menstrual } & 2 \\
\hline \multicolumn{3}{|l|}{ Cesárea } & 1 \\
\hline \multicolumn{3}{|c|}{ Infecção das vias aéreas superiores } & 2 \\
\hline \multicolumn{3}{|l|}{ Jejum } & 1 \\
\hline \multicolumn{3}{|l|}{ Estresse } & 2 \\
\hline \multicolumn{3}{|c|}{ Não identificado } & 6 \\
\hline \multicolumn{3}{|l|}{ TOTAL* } & 21 \\
\hline
\end{tabular}

* O fator precipitante foi identificado em três pacientes com quadros crônicos, que aqui foram considerados como crise única.

Nas crises de caráter leve as medicações estão presentes como fatores precipitantes em $33,3 \%$ das vezes, na grande maioria dos casos isoladamente (Tabela 13). Em $28,5 \%$ das crises o fator precipitante não pôde ser identificado. Outros fatores, como irregularidade menstrual, 
procedimento obstétrico não complicado, infecções de menor gravidade, jejum e estresse podem ser notados nestes casos, sendo responsáveis pelo desencadeamento de $38,0 \%$ das crises. Em 95,2\% destas crises apenas um fator precipitante foi incriminado.

\section{TABELA 14- NÚMERO DE FATORES PRECIPITANTES}

\begin{tabular}{l|c|c|c|c}
\hline \hline $\begin{array}{l}\text { Número de } \\
\text { fatores } \\
\text { nrecinitantes }\end{array}$ & Sexo & Com neuropatia & Sem neuropatia & TOTAL \\
\hline 1 & F & 7 & 12 & 19 \\
\hline \multirow{2}{*}{ ou mais } & M & 1 & 5 & 6 \\
\hline \multirow{2}{*}{ Desconhecido } & M & 17 & 7 & 24 \\
\hline & M & 7 & 0 & 1 \\
\hline
\end{tabular}

Contribuição do número de fatores precipitantes envolvidos, único ou múltiplos, no desencadeamento de uma crise de porfiria, com e sem manifestação de déficit sensitivomotor, para cada sexo, de um total de 63 crises agudas

O valor do risco relativo calculado segundo os dados da Tabela 14 foi 5,46 , indicando que há correlação entre a presença de múltiplos fatores precipitantes e o desenvolvimento de neuropatia periférica motora ou sensitivo-motora.

\section{TABELA 15- FATORES PRECIPITANTES NAS MANIFESTAÇÕES CRÔNICAS}

\begin{tabular}{|c|c|c|}
\hline \multicolumn{2}{|c|}{ Fator precipitante } & $\mathbf{N}$ \\
\hline \multicolumn{2}{|c|}{ Desconhecido } & 5 \\
\hline \multicolumn{2}{|c|}{ Período pré-menstrual } & 1 \\
\hline \multirow{4}{*}{ Medicações } & Butilescopolamina & 4 \\
\hline & Anticoncepcional oral & 2 \\
\hline & Anti-epiléptico & 1 \\
\hline & Outra & 1 \\
\hline \multicolumn{2}{|l|}{$\overline{\text { TOTAL }^{*}}$} & 14 \\
\hline
\end{tabular}

* alguns pacientes relataram combinação de 2 ou mais fatores precipitantes 
Nos quadros crônicos a maioria dos pacientes não havia identificado qual o fator precipitante envolvido (Tabela 15). Um número significativo mencionou o uso de medicações, entre elas a butilescopolamina, como fator associado ao desencadeamento das manifestações.

\subsubsection{Diagnóstico}

O teste de Watson-Schwartz foi realizado em todos os 37 pacientes, sendo $100 \%$ destes positivos.

O valor do ALA urinário foi obtido em seis pacientes, e o resultado foi elevado em todos estes (ANEXO D). O valor do PBG excretado encontrouse aumentado em três pacientes nos quais este dado foi recuperado. Os resultados das dosagens da URO e da COPRO estavam disponíveis em 9 pacientes cada uma, sendo que a URO esteve elevada em todos estes, enquanto que a COPRO foi normal em três dos pacientes e aumentada nos demais (ANEXO D).

A dosagem de chumbo sérico foi normal nos dois casos nos quais foi realizada: na paciente HTAK, com paresia isolada unilateral do nervo radial, e no paciente FGCD, com 6 anos de idade, com tetraparesia. Esta dosagem foi realizada na primeira paciente pela presença de mononeuropatia evocadora de intoxicação pelo chumbo, e na criança, pela ocorrência não usual de porfiria nesta faixa etária. O líquor foi realizado em 10 pacientes; em dois deles foi observado discreto aumento de proteínas, com número de 
células normal, e nos demais a celularidade e o conteúdo proteico foram normais.

Seis pacientes foram submetidos ao exame eletroneuromiográfico, e três destes resultados puderam ser obtidos: um deles foi normal, outro evidenciou padrão neurogênico nos quatro membros, mais intenso proximalmente, com sinais de desnervação abundantes, inclusive na musculatura paravertebral, e o último mostrou padrão compatível com polimiosite, com potenciais miopáticos e sinais de desnervação difusamente. Em nenhum caso houve redução da velocidade de condução sensitiva ou motora.

Na paciente cuja eletroneuromiografia demonstrou padrão miopático foi realizada biópsia muscular, que evidenciou atrofia de fibras compatível com doença neurogênica primária. Outro paciente foi submetido a biópsia do nervo sural (Figura 11- Foto).

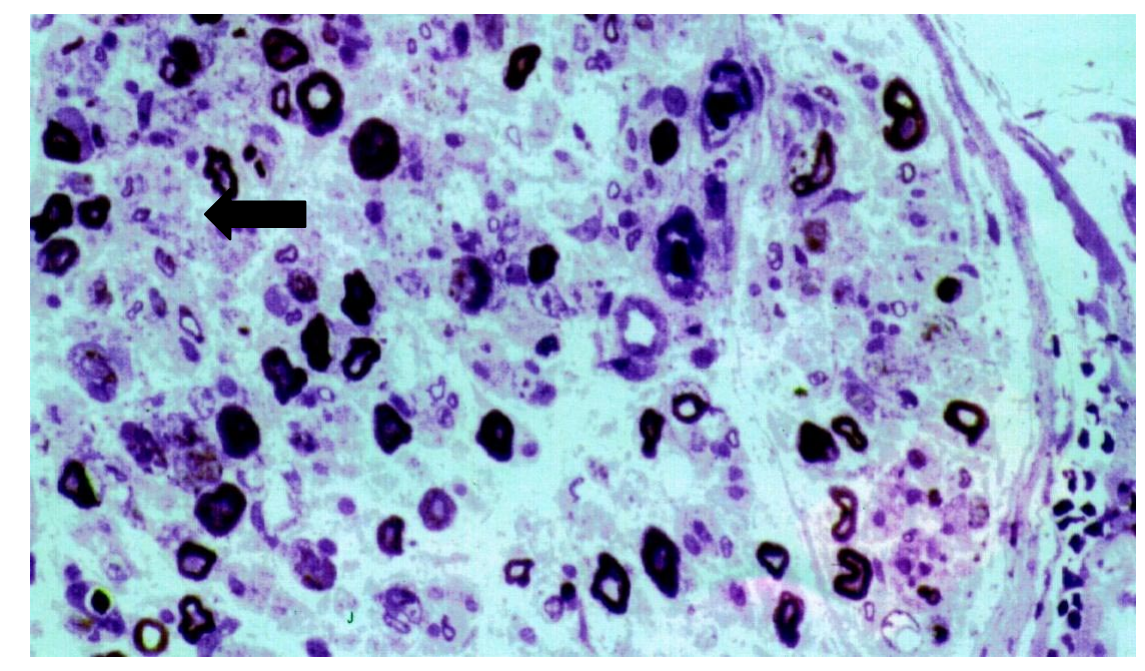

Figura 11 - Foto com aumento de 40 x. Biópsia de nervo sural de paciente durante surto de PAI com neuropatia periférica. Corte semifino, $1 \mu \mathrm{m}$, preparado com material fixado em glutaraldeído a $2 \%$; coloração azul-de-toluidina. Observa-se presença de câmaras de digestão (seta), indicando degeneração axonal importante. 
Tomografia computadorizada de crânio foi realizada em quatro pacientes e ressonância magnética de encéfalo em dois, e em todos estes os resultados foram normais. A análise do laudo da necrópsia do paciente CiAS revelou alterações compatíveis com quadro de hipóxia em vários órgãos, não tendo sido observados outros achados mais específicos da doença.

\subsubsection{Tratamento e Prognóstico}

Tratamento instituído em 63 crises

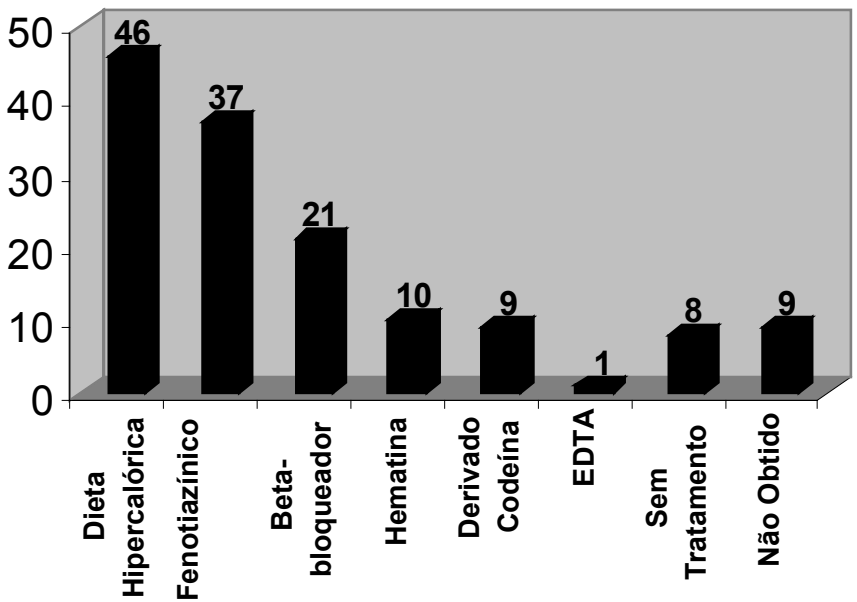

Figura 12 - Os números referem-se ao número de crises nas quais o tratamento foi instituído

Excluindo-se as crises nas quais não foi possível obtermos dados a respeito do tratamento, e aquelas nas quais nenhum tratamento específico foi instituído, observamos que todas as demais crises foram tratadas com dieta hipercalórica e administração endovenosa de glicose hipertônica (Figura 12). Hematina foi administrada em $15,8 \%$ das 63 crises, enquanto EDTA foi usado em um paciente. Em $33,3 \%$ das crises os pacientes 
receberam agentes $\beta$-bloqueadores, em $58,7 \%$, neurolépticos, e em $14,3 \%$, derivados da codeína (Figura 12).

Em $80,9 \%$ das crises houve regressão total do quadro, e em 14,2\% foram observadas seqüelas, das quais $88,9 \%$ na forma de déficit motor leve (força muscular grau IV), tendo um destes pacientes sido tratado com EDTA. O restante $(11,1 \%)$ foi descrito como alteração discreta das funções cognitivas. Em uma das crises este dado não foi obtido.

Foram constatados três óbitos entre os 37 pacientes estudados $(8,1 \%)$, sendo dois do sexo feminino e um do masculino.

\subsubsection{DOENÇAS ASSOCIADAS}

Em 20 pacientes foram encontradas outras patologias ou condições mórbidas, enquanto que 17 não apresentaram outras doenças além da PAI (Tabela 16). Em nenhum doente foi relatado câncer. Insuficiência hepática foi observada, assim como anemia, em um doente cada, porém a investigação laboratorial completa da causa não foi obtida. 


\section{TABELA 16- OUTRAS DOENÇAS OU CONDIÇÕES ASSOCIADAS}

\begin{tabular}{l|c}
\hline \hline \multicolumn{1}{c|}{ Doença } & Número de pacientes \\
\hline Endometriose & 2 \\
\hline Hipertensão arterial sistêmica & 3 \\
\hline Epilepsia & 2 \\
\hline Nefrolitíase & 2 \\
\hline Bronquite & 2 \\
\hline Hipertireoidismo & 1 \\
\hline Hipocalcemia & 1 \\
\hline Insuficiência hepática & 1 \\
\hline Abortamento habitual & 1 \\
\hline Irregularidade menstrual & 1 \\
\hline Amenorréia & 1 \\
\hline Cistites de repetição & 1 \\
\hline Insuficiência coronariana & 1 \\
\hline Síndrome de Wolf-Parkinson-White & 1 \\
\hline Gastrite & 1 \\
\hline Febre reumática & 1 \\
\hline Miocardite & 1 \\
\hline Pericardite & 1 \\
\hline Claustrofobia & 1 \\
\hline Hiperatividade & 1 \\
\hline Depressão & 1 \\
\hline Total * & 26 \\
\hline \hline Dados obtios de & 1 \\
\hline
\end{tabular}

Dados obtidos de um total de 20 pacientes nos quais alguma doença ou condição mórbida concomitante foi identificada

* 6 pacientes apresentaram mais de uma doença cada um 
5. DISCUSSÃO 


\subsection{GRUPO EstUdAdO}

\subsubsection{IDADE e SEXo}

Em nossa casuística, encontramos um paciente do sexo masculino cuja crise de PAI ocorreu em idade muito precoce, aos seis anos de idade, fato extremamente raro na literatura ${ }^{11,50}$, mesmo em grandes séries ${ }^{96}$. Por este motivo, a faixa etária de acometimento verificada no sexo masculino no nosso estudo está abaixo do que é rotineiramente encontrado. Se excluirmos este paciente, a média de idade da crise inaugural no sexo masculino subirá para 31,7 , e a mediana para 33 anos, variando a idade de início da crise inaugural entre 21 e 48 anos, o que é compatível com o observado na literatura, pois a idade de início das manifestações da porfiria é mais tardia nos homens. STEIN e TSCHUDY ${ }^{174}$ notaram relação entre idade de início tardia e pior prognóstico no grupo masculino.

KOSTRZEWSKA e GREGOR ${ }^{96}$ encontraram apenas três crianças com PAI num total de 382 pacientes, em 18 anos de seguimento. O paciente cujos sintomas manifestaram-se aos seis anos de idade apresentou como antecedente familiar uma irmã falecida aos três anos de idade com quadro clínico muito semelhante: dor abdominal intensa seguida de crises convulsivas, sendo submetida a cirurgia de emergência com hipótese diagnóstica de estenose de piloro, não confirmada, evoluindo para óbito. Segundo ELDER ${ }^{50}$, quando há manifestação clínica na criança, provavelmente trata-se de gene homozigoto ou outra variante de um dos tipos de porfiria de transmissão autossômica dominante, devendo-se porém 
afastar tirosinemia hereditária, que apresenta quadro clínico neurovisceral semelhante, e excreção excessiva de ALA na urina. A idade mais precoce de início das crises relatada na literatura é de quatro meses ${ }^{11}$, tratando-se de um paciente com quadro severo, que necessitou de ventilação mecânica. BARCLAY ${ }^{11}$ questiona se o pequeno número de crianças com PAI não seria devido ao fato de este ser um diagnóstico negligenciado nesta faixa etária, e descreve o caso de um paciente de nove anos, com crises convulsivas e evolução para coma, com duração de três dias, e completa regressão das manifestações clínicas. Observamos que talvez as crises convulsivas sejam proporcionalmente mais freqüentes em crianças, durante as crises de PAI, já que estiveram presentes tanto no paciente da nossa série, como nos poucos descritos na literatura ${ }^{11,50}$. Há também semelhança no fato de que esta criança também apresentou alucinações, o que poderia sugerir uma vulnerabilidade diferente do SNC entre adultos e crianças ao fator implicado na etiopatogenia da doença.

A idade de início mais freqüente dos sintomas foi a $3^{a}$ década para as mulheres, e a $4^{\mathrm{a}}$ para os homens, se excluído o paciente de seis anos de idade, o que concorda com os dados da série de GOLDBERG ${ }^{66}$ e STEIN e TSCHUDY ${ }^{174}$. CROSS $^{36}$ observou que a faixa etária com maior incidência de crises encontra-se entre 20 e 35 anos, em concordância com os nossos dados.

O número de mulheres acometidas foi superior ao de homens, o que também foi observado em outras séries. A doença permanece latente em mais indivíduos do sexo masculino, o que poderia ser explicado pelo papel 
que os hormônios sexuais desempenham no desencadeamento das crises. A proporção de indivíduos sintomáticos é variável entre os sexos nos diversos estudos, embora o número de mulheres afetadas seja sempre superior ao de homens: CROSS ${ }^{36}$ e WATSON ${ }^{197}$ observaram proporção de 1,5:1; GOLDBERG ${ }^{66}$, de 1,6:1; WALDENSTRÖM ${ }^{195}$ 1,4:1; SAINT e CURNOW $^{163}$ 4,3:1, e DE SIERVI et al. ${ }^{42}$ 2,3:1, enquanto nosso grupo mostrou distribuição de 2,7:1. Se analisarmos a proporção do número de crises de PAl entre os dois sexos, este valor será de 4,3:1, aproximadamente, podendo-se daí concluir que o sexo feminino apresentou, no nosso estudo, também mais crises que o masculino, mesmo não levandose em conta as formas crônicas. Se considerarmos as apresentações crônicas isoladamente, esta proporção elevar-se-á para 5,5:1. Estes valores sugerem que as mulheres estão mais sujeitas à influência de fatores precipitantes, ou que nelas existe algum fator endógeno predisponente, como os hormônios esteróides, que aumentaria a suscetibilidade ao desenvolvimento de manifestações clínicas.

\subsubsection{ANTECEDENTE FAMILIAR}

Entre os pacientes aqui estudados, observamos que aproximadamente a metade $(56,7 \%)$ referiu antecedente familiar positivo para PAl, enquanto na casuística de STEIN e TSCHUDY ${ }^{174}, 33$ entre 46 (71\%) pacientes tinham história familiar conhecida de PAI, embora não haja referência ao método usado para o diagnóstico. No estudo de GOLDBERG $^{66}, 19$ entre 50 pacientes (38\%) tinham ao menos um familiar 
com a doença ativa ou como portador, diagnosticado pelo aumento da excreção urinária de PBG, e em uma série de 25 pacientes estudada por RIDLEY ${ }^{153}$, apenas dois pacientes tinham história familiar conhecida de porfiria, enquanto que sete tinham antecedentes familiares de sintomas que poderiam sugerir ataques de PAI. No entanto, em apenas um caso deste último estudo a história familiar de porfiria contribuiu para o diagnóstico correto. Em todos os outros casos, a história familiar só tornou-se evidente depois que o diagnóstico de porfiria havia sido estabelecido. Esta discrepância entre esses valores encontrados provavelmente reflete diferentes metodologias, com sensibilidade variável para o estabelecimento do diagnóstico. Na nossa série, em particular, a porcentagem de parentes acometidos provavelmente não é maior pela dificuldade em estabelecer o diagnóstico de porfiria. Isto ocorre tanto pelo fato de não haver suspeita clínica, ou por não dispormos rotineiramente em nosso meio de testes mais sofisticados, para serem usados em larga escala, como o estudo da enzima deficitária, ou o mapeamento genético. Inferimos, no nosso estudo, que a porcentagem real de pacientes com antecedente familiar positivo, e mesmo o número de familiares acometidos, devem ser maiores, já que muitos dos pacientes relatam episódios de doença na família que poderiam eventualmente ser atribuídos à porfiria, como dores abdominais de origem não esclarecida, quadros epilépticos, falecimento durante ou após cirurgias abdominais, embora o diagnóstico não tenha sido firmado. Os estudos mais recentes não levam em consideração o número de familiares acometidos clinicamente, e sim o número de portadores do gene. 


\subsection{MANIfestaÇões ClínICAS}

\subsubsection{SinAIS E SintomaS}

Observa-se que o quadro clínico na nossa casuística variou nos pacientes de uma crise a outra, embora alguns padrões fossem mantidos na maior parte delas. RIDLEY ${ }^{154}$ considera que tanto o intervalo quanto 0 número de crises, e mesmo as características das manifestações são variáveis de uma crise a outra no mesmo paciente, o que sugere que os fatores precipitantes tenham influência na forma como a doença irá manifestar-se, pois se o quadro clínico dependesse apenas do genótipo, o mesmo indivíduo apresentaria sinais e sintomas semelhantes em diferentes crises.

\subsubsection{QUadro CLínico InAUguraL}

Em geral, a crise de PAI progride seguindo certa ordem na sucessão de eventos: primeiramente a dor abdominal, em seguida as manifestações psiquiátricas, e por fim os déficits neurológicos. Nem sempre este é o padrão de evolução observado nestes pacientes. Alguns pacientes relatam sintomas que poderiam constituir uma fase prodrômica da doença, como mal-estar vago, dores inespecíficas, difusas, e alterações do sono.

Os distúrbios do sono, especialmente a insônia, parecem estar relacionados às fases iniciais da crise de porfiria. Desde os primeiros relatos 
na literatura ${ }^{77,175}$ a sua ocorrência é constantemente observada, e, pelo menos nestes casos, parece ter tido papel importante na determinação do agravamento do quadro clínico, já que estes pacientes eram sistematicamente medicados com hipnóticos, como o sulfometano, o que certamente contribuiu para a piora do prognóstico desses indivíduos. É ainda discutível se a insônia em si seria já parte integrante do quadro porfírico, ou apenas um fator que indiretamente levaria à precipitação do quadro, pelo uso de medicações sedativas e hipnóticas. Observamos, porém, que alguns dos pacientes que apresentam insônia numa fase inicial, prodrômica, da crise de PAI, não chegam a fazer uso de medicações contra-indicadas, como sedativos e benzodiazepínicos, e mesmo assim apresentam progressão do quadro clínico, com aparecimento de outras manifestações típicas, como dor abdominal, o que sugere que o distúrbio do sono, assim como os pesadelos relatados por alguns pacientes, sejam já parte integrante da crise porfírica, e não apenas fatores que indiretamente propiciem a precipitação da crise. Muitas vezes este dado não é questionado ao paciente ou não é valorizado na anamnese, e por isso não há na nossa série como estudar a real freqüência com que este sintoma se apresenta. Acreditamos que a pesquisa sistemática desta manifestação elevaria consideravelmente a porcentagem de pacientes com distúrbios do sono.

STEIN e TSCHUDY ${ }^{174}$ observaram dor abdominal em 36 entre 46 pacientes $(78,2 \%)$; dor abdominal concomitante com neuropatia periférica em três, dores nas extremidades em um, e hipotensão postural severa, com episódio sincopal, como primeira manifestação de PAI, em dois dos 46 
pacientes estudados. GOLDBERG ${ }^{66}$ também descreveu dor abdominal como o sintoma inicial mais freqüente, seguido de dor abdominal associada a obstipação, em seguida, associada a vômitos, dores não-abdominais, dores abdominais com alterações sensitivas, dor abdominal e diarréia, crises convulsivas e depressão, nesta ordem. Conclui-se, portanto, que as manifestações mais comuns neste tipo de porfiria são as decorrentes da neuropatia autonômica.

As manifestações psiquiátricas também são relatadas ocasionalmente como inaugurais da crise de porfiria, às vezes retardando o diagnóstico pela falta de colaboração do paciente em relação ao fornecimento de dados. Como exemplo, CARNEY ${ }^{29}$ relata quatro casos nos quais o quadro inicial foi psiquiátrico (neurose, histeria, depressão e fobia), e cujo diagnóstico só foi firmado após a segunda crise, quando outros sinais e sintomas surgiram.

Somente em duas das 29 crises estudadas por RIDLEY ${ }^{153}$ a neuropatia foi o quadro inaugural da crise. Exceto por dois casos da série de STEIN e TSCHUDY ${ }^{174}$, todos os ataques em que ocorreu neuropatia iniciaram-se por sintomas mentais ou abdominais. RIDLEY ${ }^{153}$ estudou 25 pacientes com PAl, perfazendo 29 crises, com idades entre 18 e 58 anos, e os sintomas iniciais foram abdominais em 24 surtos, e distúrbios mentais em cinco. Em duas destas crises, os sintomas abdominais associaram-se com confusão mental, e em duas outras, com neuropatia periférica. Na nossa casuística, a dor abdominal sempre precedeu o desenvolvimento de déficits motores. 


\subsubsection{CaRACterísticas das MANifestações Clínicas}

Observamos que as manifestações do SNP foram mais freqüentes do que as do SNC, o que sugere uma maior suscetibilidade deste sistema à ação dos fatores ou substâncias envolvidos na etiopatogenia da PAl, como por exemplo ao acúmulo de ALA e aos efeitos dos radicais livres. Isto ocorre provavelmente devido à presença da barreira hematoencefálica, que se tornaria permeável à passagem destas substâncias apenas em casos mais graves.

As manifestações clínicas numa crise porfírica podem ser agrupadas em diversos grupos sindrômicos. Na mesma crise o paciente pode apresentar diversas síndromes, e o mesmo paciente em crises diferentes pode apresentar quadros clínicos muito diferentes entre si.

É pequeno o número de séries relatadas de pacientes com PAI (Tabela 17), já que esta é uma doença rara, muitas vezes de evolução crônica, e provavelmente sub-diagnosticada, devido às múltiplas formas de apresentação clínica possíveis, embora, por esta mesma razão, devesse com maior freqüência ser lembrada entre o rol de diagnósticos diferenciais de várias afecções. A maior casuística é a de WALDENSTRÖM ${ }^{195}$, de 1957, com 321 casos estudados de PAl. Segue-se a esta, em número de pacientes, a de DE SIERVI et al. ${ }^{42}$, com 240 pacientes. Muitos autores agregam em suas séries pacientes com vários tipos de porfiria, impossibilitando a identificação e a extração das manifestações clínicas 
específicas da PAI. EALES e LINDER $^{49}$, por exemplo, estudaram 80 pacientes com porfiria, porém apenas sete eram de PAI.

\section{TABELA 17- SINTOMAS E SINAIS NAS DIVERSAS SÉRIES ESTUDADAS}

\begin{tabular}{|c|c|c|c|c|c|c|}
\hline Quadro clínico & $\begin{array}{c}\text { Waldenström } \\
1957 \\
n=321\end{array}$ & $\begin{array}{c}\text { Goldberg } \\
1959 \\
n=50 \\
\end{array}$ & $\begin{array}{c}\text { Stein; } \\
\text { Tschudy } \\
1970 \\
n=46\end{array}$ & $\begin{array}{c}\text { Nordmann } \\
\text { et al. } \\
1999 \\
n=* \\
\end{array}$ & $\begin{array}{c}\text { De Siervi } \\
\text { et al. } \\
1999 \\
n=240 \\
\end{array}$ & $\begin{array}{c}\text { Presente } \\
\text { série } \\
n=37^{* \star}\end{array}$ \\
\hline Dor abdominal & 85 & 94 & 95 & 95 & 100 & 100 \\
\hline Vômitos & 59 & 88 & 43 & 90 & 11 & 40,5 \\
\hline Obstipação & 48 & 84 & 48 & 85 & 37 & 51,6 \\
\hline Diarréia & 9 & 12 & 5 & - & - & 9,7 \\
\hline Déficit motor & 42 & 68 & 60 & 12 & 59 & 58,7 \\
\hline $\begin{array}{l}\text { Manifestações } \\
\text { psiquiátricas }\end{array}$ & - & 58 & - & - & 18 & 14,2 \\
\hline $\begin{array}{l}\text { Alterações } \\
\text { sensitivas }\end{array}$ & 9 & 38 & 26 & - & - & 57,8 \\
\hline $\begin{array}{l}\text { Crises } \\
\text { convulsivas }\end{array}$ & 10 & 16 & 20 & 12 & 30 & 20,6 \\
\hline Hipertensão & 40 & 54 & 36 & 36 & - & 15,5 \\
\hline Taquicardia & 28 & 64 & 80 & 70 & 30 & 15,5 \\
\hline $\begin{array}{l}\text { Febre não } \\
\text { associada a } \\
\text { processo } \\
\text { infeccioso }\end{array}$ & 37 & 14 & - & - & - & 4,7 \\
\hline $\begin{array}{l}\text { Amaurose } \\
\text { transitória }\end{array}$ & - & - & - & - & - & 1,5 \\
\hline
\end{tabular}

Porcentagem relativa de sintomas e sinais presentes durante crise de PAI segundo diversas séries estudadas

n- número de pacientes estudados

* número de pacientes não indicado no artigo. Este trabalho refere-se a porfirias hepáticas agudas, e inclui casos de PAI, CPH, PV e D-ALA-D

** porcentagens calculadas sobre o número de crises (63)

BECKER e KRAMER ${ }^{15}$, referindo-se às séries de GOLDBERG $^{66}$ e de STEIN e TSCHUDY ${ }^{174}$, conclui que os sintomas e sinais clínicos mais freqüentes, em ordem decrescente, são: dor abdominal, obstipação, vômito, bexiga neurogênica, taquicardia, fraqueza muscular, e hipertensão. Nossa análise incluiu também outros dados, como alteração da cor da urina, diminuição do nível de consciência, alterações ventilatórias, quadros psiquiátricos e amaurose transitória. De modo geral, observa-se a mesma 
disposição estatística entre os dados do nosso estudo e os das demais séries estudadas, com freqüências bastante semelhantes às dos trabalhos de WALDENSTRÖM ${ }^{195}$, STEIN e TSCHUDY ${ }^{174}$, e DE SIERVI et al. ${ }^{42}$, particularmente.

Como verificamos, nem todas as crises de porfiria manifestam-se através de sinais neurológicos explícitos. No estudo conduzido por WALDENSTRÖM ${ }^{194}$, sintomas neurológicos, como alteração do nível de consciência, crises convulsivas e déficits motores e sensitivos, foram relatados em apenas 60 dos 143 casos $(41,9 \%)$ examinados.

Os sintomas abdominais, por outro lado, são a apresentação mais freqüente dos ataques de PAI, sendo às vezes a única manifestação desta. Quando ocorre juntamente com a neuropatia, precede-a quase sempre. Note-se que a taquicardia e a obstipação são sintomas também presentes ocasionalmente na Síndrome de Landry-Guillain-Barré-Strohl. ALBERS et al. ${ }^{3}$ observaram 11 quadros de tetraparesia entre 115 pacientes com PAl. $14,2 \%$ dos pacientes de STEIN e TSCHUDY ${ }^{174}$ com paresia motora de membros $(8,5 \%$ do total de pacientes) evoluíram com insuficiência ventilatória.

Há concordância entre a freqüência bastante alta com que os pacientes da presente série manifestaram dores abdominais como parte da crise porfírica, e a encontrada pelos autores que estudaram grandes séries de casos de PAl, com a ressalva de que o fato de $100 \%$ dos pacientes aqui avaliados terem apresentado dores abdominais pode significar que a suspeita diagnóstica seja por hábito feita fundamentalmente sobre este dado 
clínico, e quando este encontra-se ausente num paciente com porfiria, a hipótese pode equivocadamente ter sido afastada. Numa população de 240 pacientes argentinos este valor também foi de $100 \%$, observando-se que nesta última série em todas as vezes este quadro doloroso esteve presente como manifestação inicial da crise ${ }^{42}$.

Notamos que na maioria das vezes a duração da dor abdominal tem um padrão sub-agudo de evolução, o que poderia sugerir que a disfunção metabólica já estivesse em curso quando algum fator precipitante provocasse a descompensação do quadro, e que na fase inicial haveria um relativo equilíbrio graças a algum mecanismo compensatório fisiológico. Constatamos que muito freqüentemente a dor é do tipo cólica, como relatado por outros autores ${ }^{63,66}$. Geralmente a dor é de distribuição difusa pelo abdome, porém um considerável número de pacientes apresentam dor localizada em regiões específicas do abdome, mais freqüentemente no andar inferior do mesmo. Em 20,4\% dos pacientes observa-se dor na região lombar, mais comumente associada à abdominal, porém existindo também isoladamente, podendo ser confundida com quadros renais.

Observamos que parte dos pacientes refere dores abdominais cronicamente, às vezes desde a infância, com características semelhantes à da dor observada durante crise documentada de PAI. A ocorrência de dor abdominal num padrão de recorrência bastante alto, dando origem ao quadro que seria denominado "crônico", é relatado por alguns autores, e obviamente é um dado que, isoladamente, dificilmente levaria ao diagnóstico de porfiria, e que, neste caso, muitas vezes é valorizado apenas quando 
avaliado retrospectivamente ${ }^{22}$. Estes autores descreveram o fato de alguns pacientes com PAI apresentarem dor recorrente ou quase contínua, de localização variável (abdominal, mais freqüentemente, mas também torácica ou de membros), sendo que a maioria destes pacientes teve pelo menos um quadro agudo de exacerbação da dor, embora não necessariamente tenham desenvolvido déficit motor ou outro sintoma. Estas dores podem durar semanas, meses, ou mesmo anos, e podem também surgir e desaparecer ciclicamente nas mulheres, intimamente em relação com a menstruação. Estes autores observaram que os precursores PBG e ALA mantiveram-se elevados de forma quase contínua em todos estes pacientes.

A freqüência com que ocorrem alterações do ritmo intestinal durante uma crise varia de 53 a $96 \%$ nas diferentes séries, enquanto encontramos valor de $59,7 \%$, quando avaliados ambos os sexos conjuntamente. O sexo masculino menos freqüentemente apresenta mudança no ritmo intestinal, e, quando esta ocorre, mais comumente encontramos diarréia neste grupo, enquanto que o sexo feminino apresenta maior tendência à obstipação. Mais freqüentemente, no entanto, em ambos os sexos, observa-se obstipação e íleo paralítico, sendo a hipermotilidade intestinal e a diarréia considerados apenas como fenômenos temporários, e menos freqüentes, sugerindo que o acometimento do sistema nervoso parassimpático pode ser mais intenso que o do simpático. Na série estudada por RIDLEY ${ }^{153}$, a obstipação esteve presente em 24 dos 25 pacientes, às vezes alternada com episódios diarréicos. 
Na nossa casuística, 40,5\% das crises apresentaram-se com vômitos, enquanto na literatura observamos porcentagens maiores, destacando-se as séries de GOLDBERG ${ }^{66}$, com $88 \%$, e a de NORDMANN et al. ${ }^{137}$, com $90 \%$, embora esta última analise pacientes com todos os tipos de porfiria aguda. Por outro lado, as séries de WALDENSTRÖM ${ }^{195}$ e STEIN e TSCHUDY ${ }^{174}$, com $59 \%$ e $43 \%$, respectivamente, aproximam-se dos nossos resultados. $A$ presença deste sintoma, conjuntamente com o quadro doloroso abdominal, habitualmente dirige o diagnóstico para uma afecção nesta região. Por isso, a sua freqüência relativamente alta nos pacientes com porfiria deve ser ressaltada para que o diagnóstico de PAI seja incluído como diferencial entre os quadros obstrutivos e inflamatórios da região abdominal.

Muitas vezes não é observada alteração da cor da urina quando destes episódios dolorosos, porém a ausência deste sinal não invalida o diagnóstico de PAl, pois sabe-se que muitas vezes a urina só muda de cor após um ou dois dias de exposição à luz. Mesmo casos mais severos, com quantidades excessivas de precursores e porfirinas na urina, podem não apresentar mudança característica na coloração, inclusive após a acidificação e exposição à luz ${ }^{146}$. Apenas em $75 \%$ dos pacientes analisados por STEIN e TSCHUDY ${ }^{174}$ foi observada alteração na cor da urina, mesmo se especificamente questionados a respeito, enquanto que nossa casuística demonstra esta manifestação em $95,2 \%$ dos pacientes, não havendo diferença entre os sexos, o que pode novamente remeter à conclusão de que algumas vezes o diagnóstico de porfiria não é suspeitado na ausência deste parâmetro. 
STEIN e TSCHUDY ${ }^{174}$ observaram paresia flácida de membros em $60 \%$ de seus pacientes, valor este semelhante ao de nosso estudo $(58,7 \%$ das crises), e RIDLEY ${ }^{153}$ relata que do total de 25 pacientes estudados, 15 já haviam apresentado 18 ataques sem neuropatia periférica, previamente à crise em que ela esteve presente.

A maioria dos nossos pacientes apresentou déficit motor predominantemente proximal, em conformidade com os dados encontrados nas diversas séries aqui citadas. Além disso, encontramos dois pacientes nos quais o acometimento foi relativamente aleatório, em um deles predominando proximalmente nos membros inferiores e distalmente nos membros superiores, no outro observando-se o padrão inverso. O padrão de distribuição do déficit motor é descrito na literatura como imprevisível ${ }^{63}$, seja em relação ao número de membros afetados ou à sucessão em que este acometimento ocorre. $\mathrm{Na}$ nossa casuística podemos notar grande predominância de polineuropatia nos quatro membros, havendo apenas um caso no qual foi observada mononeurite do radial. GARCIN e LAPRESLE ${ }^{63}$ descrevem acometimento unicamente do extensor do $3^{\circ}$ dedo de uma mão em um de seus pacientes, demonstrando que o envolvimento apenas de um ramo de nervo periférico é possível na PAI, embora muito raro. RIDLEY e CAVANAGH $^{152}$ relataram um caso em que o déficit motor instalou-se no membro superior direito, especialmente na musculatura extensora, mas também no músculo serrátil anterior, que uma semana antes haviam sido particularmente muito exercitados, e cuja fraqueza foi precedida por quadro doloroso local, concomitantemente ao início de uma crise de porfiria, com 
dores abdominais e alteração da cor da urina. Os autores sugeriram que o aumento da demanda metabólica neuronal no local exercitado pode não ter encontrado oferta adequada de algumas substâncias, como por exemplo piridoxal fosfato, que hipoteticamente estaria já parcialmente depletado, e seria o suficiente para deflagrar o processo de "dying-back" no respectivo nervo periférico. Esta é uma observação isolada, e parece-nos que este caso guarda algumas semelhanças - no fator desencadeante (exercício), modo de instalação, musculatura acometida, e regressão espontânea após algumas semanas - com a amiotrofia neurálgica descrita por PARSONAGE e TURNER $^{140}$, sendo necessário que uma investigação mais ampla seja feita a respeito da relação entre exercício e território dos nervos acometidos na crise de porfiria. GARCIN e LAPRESLE ${ }^{63}$ sustentam que aproximadamente o dobro de pacientes tinham acometimento inicial da fraqueza nos membros superiores, em relação aos membros inferiores. Este dado não pôde ser obtido nesta casuística devido à falta de informações a este respeito num número considerável de pacientes. Em concordância com o maior acometimento proximal, observamos que uma parcela significativa dos pacientes apresentou alteração dos reflexos bicipitais e patelares, com relativa preservação dos aquileus.

Aproximadamente $60 \%$ das crises com neuropatia periférica apresentou-se, além da forma motora classicamente descrita, acompanhada de sintomas sensitivos proeminentes, como parestesias e disestesias, que muitas vezes causaram mais incômodos aos pacientes do que o déficit motor propriamente dito. Isto vai contra o conceito difundido de que a 
neuropatia encontrada na porfiria é puramente motora, e é importante na medida em que amplia o número de ocasiões nas quais a suspeita diagnóstica deve ser considerada. Não encontramos relatos de pacientes que inauguraram a neuropatia periférica através de sintomas sensitivos, progredindo posteriormente para acometimento motor.

A hipótese de que haveria comprometimento também da junção neuromuscular, sustentada por FELDMAN et al. ${ }^{54}$ não nos parece plausível, já que em nenhuma das grandes casuísticas encontramos dados compatíveis com manifestações clínicas e eletroneuromiográficas de síndrome miastênica.

STEIN e TSCHUDY ${ }^{174}$ relatam taquicardia em $80 \%$ dos seus doentes, chegando a utilizá-la como bom indicador de atividade da doença, enquanto que nos nossos pacientes raramente $(15,5 \%)$ foi observada taquicardia. Esta discrepância pode advir da possibilidade de que este sinal tenha caráter transitório em alguns pacientes, e, na ausência de monitorização contínua, este dado pode passar desapercebido. SAINT e CURNOW ${ }^{163}$, na avaliação de 17 pacientes, notaram que taquicardia sinusal estava presente em todos, na fase aguda da crise, o que, segundo o autor, é um dado importante, na ausência de febre, para o diagnóstico. Deve-se, porém, ressaltar que a taquicardia, por si só, da mesma forma, na presença de dor intensa, febre e agitação, não pode ser considerada como dado isolado, eventualmente decorrente também de neuropatia, e pensamos que estudos mais aprofundados sobre a condição do sistema neuro-vegetativo devam ser realizados. Sintomas e sinais autonômicos como hipo, hiperidrose, e 
alterações na distribuição topográfica da sudorese foram minuciosamente relatados por alguns autores. Estudos prospectivos para a análise desses sintomas são necessários para maior acurácia diagnóstica. STEIN e TSCHUDY $^{174}$ relataram hipotensão postural em dois pacientes como sintoma inicial da crise de PAl, o que não foi observado em nenhum caso da nossa série.

Crise epiléptica foi uma manifestação relativamente rara quando comparada às outras, ocorrendo em $20,6 \%$ das crises, porém concordante com a maior porcentagem observada na literatura ${ }^{174}: 20 \%$, generalizadas, enquanto outros autores encontraram freqüências ainda menores: WALDENSTRÖM $^{195}: 10 \%$; GOLDBERG ${ }^{66}: 16 \%$; NORDMANN et al. ${ }^{137}: 12 \%$.

As manifestações psiquiátricas estiveram presentes em aproximadamente $11 \%$ das crises apresentadas pelos pacientes do nosso estudo, com intensidades variáveis. GOLDBERG ${ }^{66}$ relatou predominância dos seguintes quadros: depressão, histeria e ansiedade, seguidos de alucinações e alterações de personalidade. Em uma das pacientes do presente estudo foi observada depressão crônica, com exacerbação durante as crises de porfiria, inclusive com tentativas de suicídio, o que já foi descrito na literatura em relação à PAI por MASON et al. ${ }^{116}, \mathrm{CROSS}^{36}$, e STEIN e TSCHUDY ${ }^{174}$. 16 entre 40 pacientes estudados por STEIN e TSCHUDY ${ }^{174}$ apresentaram alucinações ou confusão mental, em dois casos concomitantes à hiponatremia. PETERS et al. ${ }^{146}$ relatam a presença de quadros psiquiátricos em $58 \%$ de seus pacientes. Nossos dados mostram número bem menor de acometimento da esfera mental, quando avaliados 
ambos os sexos, elevando-se para $25 \%$ se considerado apenas o sexo masculino. Esta diferença entre as séries estudadas pode ser devida à seleção do grupo estudado, pois obviamente esta porcentagem eleva-se quando o paciente provém de unidades psiquiátricas, o que não ocorreu em nenhum dos nossos casos. Além disso, sintomas psiquiátricos de menor intensidade, como depressões leves ou insônia, podem ser atribuídos à própria condição do doente, sendo às vezes subestimados. Outra consideração refere-se à dificuldade em diagnosticar sintomas psiquiátricos num paciente com confusão mental.

A hiperatividade observada na criança deste estudo deve a princípio ser considerada como quadro coincidental, e não primariamente relacionada à crise de PAI, pois era condição já existente antes da manifestação porfírica.

A disfunção dos nervos cranianos é uma manifestação relativamente pouco comum, presente apenas quando há neuropatia motora de membros e, dentre os nervos mais freqüentemente acometidos, encontramos primeiramente aqueles que inervam a musculatura bulbar e em seguida o nervo facial. Em nenhum paciente foi observada paresia da musculatura ocular, extrínseca ou intrínseca. Estes dados diferem daqueles da literatura, quanto à preferência dos nervos atingidos, já que BAKER e WATSON ${ }^{10}$ observaram que as alterações patológicas mais freqüentemente são observadas nos núcleos do VII e do XII nervos cranianos, e no núcleo dorsal do $X$, em ordem decrescente. STEIN e TSCHUDY ${ }^{174}$ encontraram 
acometimento do VII nervo craniano em 15\%, da musculatura ocular em $10 \%$, e da musculatura bulbar também em $10 \%$.

Relatamos um caso com amaurose cortical, já que acometimentos de outras estruturas das vias óticas foram afastados através de exames adequados. HARLEY ${ }^{77}$, em 1890, foi provavelmente o primeiro autor a descrever amaurose transitória, com duração de três dias, em uma de suas pacientes, e, mais recentemente, STEIN e TSCHUDY ${ }^{174}$ também relataram dado semelhante na sua casuística, ressaltando-se que nestes dois casos a amaurose também foi apenas transitória, havendo recuperação da visão após a crise.

O fato da maioria dos sinais referentes ao SNC serem alteração do nível de consciência, quadros psiquiátricos e crises convulsivas reforça a idéia de que neste setor os distúrbios são meramente funcionais, pois estas manifestações isoladas em geral são decorrentes de distúrbios transitórios. A raridade com que nos deparamos com sinais focais, como amaurose e sinais de liberação piramidal, sugere que, ao contrário do SNP, aqui as lesões estruturais são a exceção. Ainda não é conhecido o mecanismo que determina a peculiaridade do acometimento nestes dois sistemas.

\subsubsection{FreqüÊnCIA e Gravidade das CRISeS}

Em relação à freqüência das crises, STEIN e TSCHUDY ${ }^{174}$ observaram que 19 entre 46 pacientes tinham apresentado menos de três crises durante toda sua vida, enquanto que 23 apresentaram crises mais constantemente, duas a três vezes ao ano. Estes dados são compatíveis 
com os nossos, pois encontramos $54 \%$ dos pacientes com menos de três crises, sendo $37,8 \%$ com apenas uma, e $35,1 \%$ dos pacientes enquadrandose no grupo com manifestações extremamente freqüentes, várias vezes ao ano.

Ressaltamos a existência de uma forma de apresentação relativamente freqüente entre os pacientes com PAI, mas pouco relatada e estudada: as manifestações crônicas da doença. Não se sabe se ela é representativa de um padrão genético diverso, porém sua presença indica que o distúrbio metabólico, e conseqüente indução da ALA-S, está constantemente presente, o que pode ter implicações terapêuticas, na evolução e no prognóstico da doença para determinados pacientes. É provável que haja relação com os diferentes perfis enzimáticos identificados através de reações imunológicas ${ }^{5}$.

Observamos que os pacientes com quadros graves raramente tinham previamente apresentado padrão de recorrência freqüente das crises, sendo estas mais raras ao longo da vida, porém de maior gravidade quando ocorrem, enquanto as crises leves são mais freqüentes entre os indivíduos com padrão de manifestação crônica, assim como entre aqueles que já apresentaram várias crises agudas. Estes dados podem ser indicadores de que a suspeita diagnóstica de PAI ocorre mais precocemente em pacientes com antecedentes de sintomas recorrentes sugestivos desta doença.

KAUPPINEN e MUSTAJOKI ${ }^{91}$ estudaram o comportamento das crises de 50 pacientes durante 23 anos, e observaram recorrência da crise em um terço dos pacientes que já haviam apresentado um primeiro episódio. Por 
outro lado, menos de $6 \%$ dos portadores até então assintomáticos, diagnosticados através de relação de parentesco com paciente afetado com confirmação genética do defeito enzimático, manifestaram sua primeira crise de PAI. WALDENSTRÖM e VAHLQUIST ${ }^{196}$ já haviam observado que a excreção de PBG é consideravelmente maior no grupo de pacientes com porfiria em atividade do que naqueles em fase latente, e KAUPPINEN e MUSTAJOKI ${ }^{91}$, em 1992, descreveram achados semelhantes, concluindo que o risco de apresentação de crises subseqüentes tem relação direta com a excreção urinária de PBG durante o período assintomático. Concluíram então que a probabilidade de manterem-se assintomáticos é maior no grupo de pacientes portadores, com doença latente, que habitualmente excretam níveis menores de PBG. Esta diferença na quantidade de precursor excretado provavelmente deve-se a diferenças no tipo de mutação genética.

Em relação à gravidade das crises agudas, notamos que há uma distribuição relativamente equalitária entre as de caráter leve, moderado e grave, com leve predomínio das de caráter moderado, não havendo diferença significativa entre os sexos. Nos quadros crônicos, o padrão observado é sempre leve, o que concorda com as constatações de KAUPPINEN e MUSTAJOKI ${ }^{91}$. Conclui-se, então, que as crises leves são extremamente mais freqüentes do que as graves, inclusive se observarmos os dois sexos separadamente. SAINT e CURNOW ${ }^{163}$ notaram que a evolução de pacientes do sexo feminino foi pior que a do sexo masculino, o que não concorda com a nossa casuística. 


\subsubsection{Fatores Precipitantes}

WALDENSTRÖM ${ }^{195}$ já havia notado a raridade da manifestação clínica da PAl antes da introdução de drogas porfirinogênicas, como barbitúricos e sulfonamidas, e CRIMLISK ${ }^{35}$ afirma que o uso mais difundido destas drogas e o maior consumo de álcool levaram a maior manifestação clínica do defeito genético subjacente. O fenômeno de interação entre fatores superimpostos e defeito genético é comum a todas as porfirias herdadas. $O$ termo doença "toxicogenética" foi introduzido recentemente ${ }^{130}$, e é adequado para a compreensão do mecanismo interativo entre fatores herdados, inerentes ao indivíduo, e o papel modulador que o ambiente exerce sobre a apresentação da doença. Os fatores precipitantes não são sempre de origem exógena, pois o fato de alguns pacientes ingerirem medicações reconhecidamente causadoras da crise de PAI, como barbitúricos, sem alterações dietéticas significativas, e não apresentarem manifestações clínicas, sugere ainda que outros fatores, possivelmente endógenos, possam estar envolvidos no mecanismo desencadeante de surtos, embora os endógenos sejam provavelmente responsáveis pelas formas menos severas da doença. Corroborando esta hipótese, há o fato que nas crianças portadoras do gene defeituoso, as drogas raramente são fatores desencadeantes. KAPPAS et al. ${ }^{89}$ relatam uso de fenilhidantoína e fenobarbital em uma paciente epiléptica, do sexo feminino, ainda na fase pré-puberal, na qual o diagnóstico foi feito através de estudo genético, e esta paciente nunca apresentou sintomas clínicos ou elevação urinária de PBG. 
Uma das principais incógnitas a respeito da PAI refere-se ao fato de apenas uma pequena porcentagem de portadores do defeito genético desenvolverem a doença, mesmo quando expostos a fatores reconhecidamente desencadeantes de crises. Notou-se que nos pacientes nos quais havia manifestação clínica coexistia a deficiência de uma enzima hepática, a $5 \alpha$-redutase, e que esta anormalidade estava ausente nos indivíduos portadores do gene nos quais a PAl sempre manteve-se no seu estado latente ${ }^{89}$. Além disso, sabe-se que esta redução favorece a formação compensatória dos metabólitos dos esteróides de configuração $5 \beta$, que são conhecidos como potentes indutores da ALA-S, o que aumentaria a suscetibilidade à manifestação do quadro clínico ${ }^{4}$. Talvez outras alterações genéticas, além do defeito na URO-S, sejam fatores decisivos para que haja ou não manifestação de sintomas clínicos nestes pacientes. ELDER ${ }^{51}$ sugere que fatores herdados definidos em outros loci genéticos provavelmente também sejam decisivos para a manifestação ou não dos sintomas nos portadores. Não há relação direta entre a excreção de PBG e o grau de deficiência de $5 \alpha$-redutase, indicando que este defeito não é a única explicação em todos os pacientes para a expressão clínica do defeito enzimático fundamental ${ }^{4}$.

Outra questão a ser respondida na PAI refere-se ao fato de somente alguns pacientes desenvolverem durante a crise neuropatia periférica, ou apresentarem evolução menos favorável que outros. Pela estatística de RIDLEY $^{153}$, a administração de barbitúricos seria o fator diferencial para que houvesse neuropatia, o que vai ao encontro dos trabalhos e conclusões de 
WALDENSTRÖM ${ }^{194}$ e GOLDBERG ${ }^{66}$. RIDLEY ${ }^{153}$ vai além e chega a afirmar que a insônia e o cansaço são os dois fatores de risco mais importantes em uma fase inicial de uma crise de PAI, já que levam freqüentemente o paciente a fazer uso de barbitúricos, desencadeando assim a neuropatia periférica da PAI, concluindo que os ataques de porfiria por ela complicados são quase sempre induzidos por $\operatorname{drogas}^{154}$. É possível que a heterogeneidade observada nos aspectos genéticos seja refletida na forma de apresentação clínica, determinando que alguns pacientes tenham manifestações mais graves, ou maior suscetibilidade à ação de fatores exógenos, tornando o seu quadro clínico mais severo. Seria necessária uma confrontação entre as diversas mutações encontradas e os respectivos quadros clínicos para que esta hipótese fosse testada, embora tenhamos observado anteriormente que o mesmo paciente apresentou crises de gravidade diversa em vários casos, inferindo-se que fatores exógenos são determinantes da gravidade em alguns casos.

$\mathrm{Na}$ nossa série observamos que a multiplicidade de fatores precipitantes e as medicações foram os aspectos que mais se correlacionaram com o desenvolvimento de crises graves e com neuropatia periférica. DE SIERVI et al. $^{42}$ também observaram que os ataques freqüentemente são provocados pelos efeitos simultâneos e cumulativos de múltiplos agentes desencadeantes. Os anti-epilépticos foram as medicações com maior participação no desencadeamento de crises graves, seguidos pela butilescopolamina e pelos antibióticos. Os fatores endógenos não foram isoladamente precipitantes de nenhuma das crises graves. Pode-se supor 
que a indução enzimática da ALA-S mantenha-se por períodos mais prolongados quando estimulada por drogas exógenas, com indução do citocromo $\mathrm{P}_{450}$, assim como quando há interação conjunta de mais de um fator precipitante da crise. Nas crises leves e sem neuropatia periférica foi maior o número de fatores precipitantes não identificados que nas severas, sugerindo que talvez estes fatores sejam de origem metabólica ou hormonal endógena. Neste grupo em geral os agentes desencadeantes da crise foram únicos, e freqüentemente estes fatores foram identificados como irregularidades menstruais, jejum e mesmo estresse. O papel do estresse ainda não está claro, porém pode-se imaginar que ocorra aumento dos níveis de cortisol, pela alteração na produção de hormônios da supra-renal. Se considerarmos que o processo infeccioso viral de vias aéreas superiores é uma entidade que em si mesma não teria papel no desencadeamento de crises, e que provavelmente a sua ação deu-se através de mecanismos indiretos, como redução da ingestão calórica e aumento do estresse, a participação de mecanismos puramente endógenos está presente em 33,3\% das crises leves. Somando-se os fatores não identificados $(28,5 \%)$ a estes endógenos $(33,3 \%)$, obtemos o valor de $61,8 \%$. ORTEGA et al. ${ }^{139}$ descreveram, em 25 pacientes com porfiria, uso de drogas - habitualmente duas ou mais - em mais de $50 \%$ das crises como fator desencadeante; gestação em $30 \%$ das pacientes do sexo feminino, embora algumas destas não tenham apresentado episódio de porfiria em gestações subseqüentes, e, em menor proporção; cirurgias e exercícios intensos. Estresse emocional foi listado como fator precipitante por três pacientes: em dois como fator 
isolado, e em um associado a outros fatores, concordando com GARCIN e LAPRESLE $^{63}$, que também o citam. Em 10 dos 25 pacientes de ORTEGA et al. ${ }^{139}$ não foi identificado qualquer fator causal. Entre as mulheres com PAI existe um grupo cujos sintomas clínicos são precipitados pelo ciclo menstrual ou pela gravidez ${ }^{38,209}$, e em nossa casuística encontramos oito crises cujas manifestações foram temporalmente relacionadas a estes fatos, sendo cinco delas concomitantes com outros fatores, como processo infeccioso, uso de medicações e procedimentos cirúrgicos, dificultando a avaliação da real influência que os hormônios podem exercer no desencadeamento de crises. Galactorréia também foi observada em algumas pacientes, o que atualmente é relacionado nas crises de PAI à disfunção hipotalâmica. A gestação pode se apresentar como conjunção de múltiplos fatores desencadeantes da crise de porfiria, como num caso descrito por SHENHAV et al. ${ }^{172}$ : ocorrência de alterações hormonais, com elevação de estradiol, hiperemese, levando ao jejum, e uso de drogas antieméticas, como metoclopramida. KOSTRZEWSKA e GREGOR ${ }^{96}$ afirmam que em $20 \%$ das pacientes de sua série as crises ocorreram no período prémenstrual, não deixando claro, porém, se algum outro fator precipitante concomitante foi identificado.

A reação a determinada droga com porfirinogenicidade conhecida não é sempre previsível, pois nem todos os pacientes com PAl terão efeitos adversos com o uso da mesma substância. RATNAIKE e BLAKE ${ }^{150}$ sugerem que a administração de drogas porfirinogênicas, quando necessária, ou de efeito desconhecido, seja monitorada através dos níveis urinários de PBG. É 
interessante notar que alguns autores relatam uso de drogas reconhecidamente porfirinogênicas, como furosemida, sulfoniluréias e teofilina, sem qualquer efeito sobre o desencadeamento de crises entre seus pacientes $^{91}$. Em relação às bebidas alcoólicas, observaram que apenas $40 \%$ dos pacientes relataram sintomas sugestivos de porfiria após o seu consumo, e que estes foram leves na maioria das vezes, concluindo que, quando ingerido de forma moderada, raramente desencadeia crises sérias, enquanto que o consumo exagerado é considerado mais arriscado. Os anticoncepcionais orais também foram prescritos a suas pacientes, sob supervisão constante, e menos de $5 \%$ delas apresentaram episódio de PAI. Como estes autores incluíram não só pacientes com a doença, mas também portadores assintomáticos entre seus pacientes estudados, sugerem que a restrição absoluta de fatores potencialmente precipitantes talvez seja desnecessária, sendo esta recomendação válida apenas para os portadores na fase latente da doença. Esta permissividade não se estende àqueles com tendência a ataques freqüentes, concluindo que estes últimos seriam mais vulneráveis aos fatores desencadeantes, restando ainda conhecer o motivo pelo qual tal fato ocorre.

$\mathrm{Na}$ nossa casuística não observamos contato com solventes ou outras substâncias químicas como fatores desencadeantes de crises, em contraste com PETERS ${ }^{144}$, que identificou o contato com estes compostos em $50 \%$ de seus pacientes.

O fato dos agentes precipitantes aumentarem a indução hepática da ALA-S e a produção dos precursores das porfirinas não ajuda a diferenciar 
entre a hipótese que implica a deficiência de heme e aquela neurotóxica, a menos que possa ser demonstrado que os fatores precipitantes atuam só no fígado. Se assim for, obviamente a teoria tóxica seria favorecida. Se atuam tanto no fígado como sistema nervoso, aí causando depleção de heme, as duas hipótese seriam favorecidas, pois haveria falta de heme no sistema nervoso, e indução de ALA-S hepática, com elevação nos níveis dos precursores. Para sustentar que o ataque é conseqüência da redução na quantidade de heme no sistema nervoso pelos fatores precipitantes, seria necessário provar que ele resultaria do aumento do bloqueio na síntese de heme, do aumento do "turnover" de heme, ou aumento da ligação do heme com substâncias não essenciais, o que ainda não é corroborado pelos estudos disponíveis.

\subsubsection{Diagnóstico}

Analisando-se os dados obtidos na nossa série, observamos que o fato de $100 \%$ dos pacientes apresentarem dor abdominal, na maioria dos casos acentuada, e quase a mesma proporção, urina avermelhada, é provavelmente indicador de que a suspeita diagnóstica de PAI só ocorre quando estes sintomas e sinais são proeminentes, e que eventualmente um quadro de neuropatia periférica em que a dor abdominal ou obstipação não sejam tão intensos pode equivocadamente ser atribuído a outra doença que não a PAI.

Em relação aos quadros crônicos, ou cíclicos, de recorrência bastante alta, especialmente nas mulheres pode haver dificuldade em suspeitar-se do 
diagnóstico, pois muitas vezes os sintomas são evocadores da síndrome de tensão pré-menstrual, com dor abdominal em cólica e alteração do humor, devendo-se recorrer à dosagem dos precursores para que haja maior certeza do diagnóstico. A dosagem de PBG pode ser útil em pacientes com dores abdominais crônicas de origem não esclarecida, cujos exames subsidiários pertinentes sejam normais.

Os sintomas manifestos na crise de PAI são inespecíficos, o que naturalmente amplia a quantidade de doenças a serem incluídas no rol do diagnóstico diferencial. Além disso, a variedade dos sintomas e sinais e a intensidade relativa com que cada um se manifesta são geralmente fatores que aumentam a dificuldade de identificação desta afecção. Quando apenas um dos sintomas da tríade clássica (dor abdominal, quadro psiquiátrico e manifestações neurológicas) está presente, ou quando apresentam-se separados por um intervalo de tempo maior, em geral há retardo no diagnóstico de porfiria, ou então a suspeita não ocorre.

Por outro lado, existe ainda a dificuldade em atribuir determinado sintoma à $\mathrm{PAl}$, em paciente com diagnóstico já previamente estabelecido, quando o quadro clínico apresenta-se incompleto, ou sem manifestações características que sugiram fortemente o diagnóstico. Um dos dilemas encontrados é a atribuição de uma dor abdominal à própria crise de PAI, ou a um processo inflamatório abdominal, como por exemplo uma apendicite. Como exemplo, tomemos a paciente LCD, que apresenta-se freqüentemente com episódios de dores em cólica, na região lombar, bilateralmente, raras vezes com alteração na cor da urina : o exame ultrassonográfico é normal, e 
a excreção dos precursores das porfirinas encontra-se persistentemente elevada. Dado o conhecimento do fato de que estes muitas vezes encontram-se elevados nos períodos intercríticos, e mesmo nos portadores que nunca manifestaram a doença, pode-se eventualmente questionar se o sintoma realmente corresponde a uma crise de PAI, dúvida esta reforçada pelo fato de muitos dos sintomas e sinais serem bastante inespecíficos, e comuns a várias outras doenças.

Outro problema que se apresenta é o do diagnóstico de epilepsia num paciente com PAl, principalmente em crianças - pois nestas a manifestação da PAl é mais rara que no adulto -, particularmente pela possibilidade de uso de drogas desencadeantes da crise porfírica ${ }^{31}$. CRIMLISK ${ }^{35}$ sugere que a confirmação de que a porfiria está etiologicamente relacionada ao quadro clínico do paciente requer a demonstração da elevação dos níveis de precursores na urina concomitantemente à ocorrência dos sintomas. Se estes encontram-se em níveis normais por ocasião de um sintoma ou sinal suspeito, provavelmente estes não podem ser atribuídos à PAI. Assim sendo, as dosagens laboratoriais são extremamente importantes para caracterizar uma crise e diferenciá-la, se possível, de outras doenças coincidentes. $\mathrm{O}$ algoritmo diagnóstico proposto por HINDMARSH ${ }^{82}$ sugere a seqüência de exames laboratoriais a serem realizados diante de um paciente com dor abdominal, com ou sem lesões cutâneas, quadro neurológico ou psiquiátrico, isolada ou conjuntamente, no qual suspeita-se que este sintoma possa ser atribuído à PAI (Figura 13): 


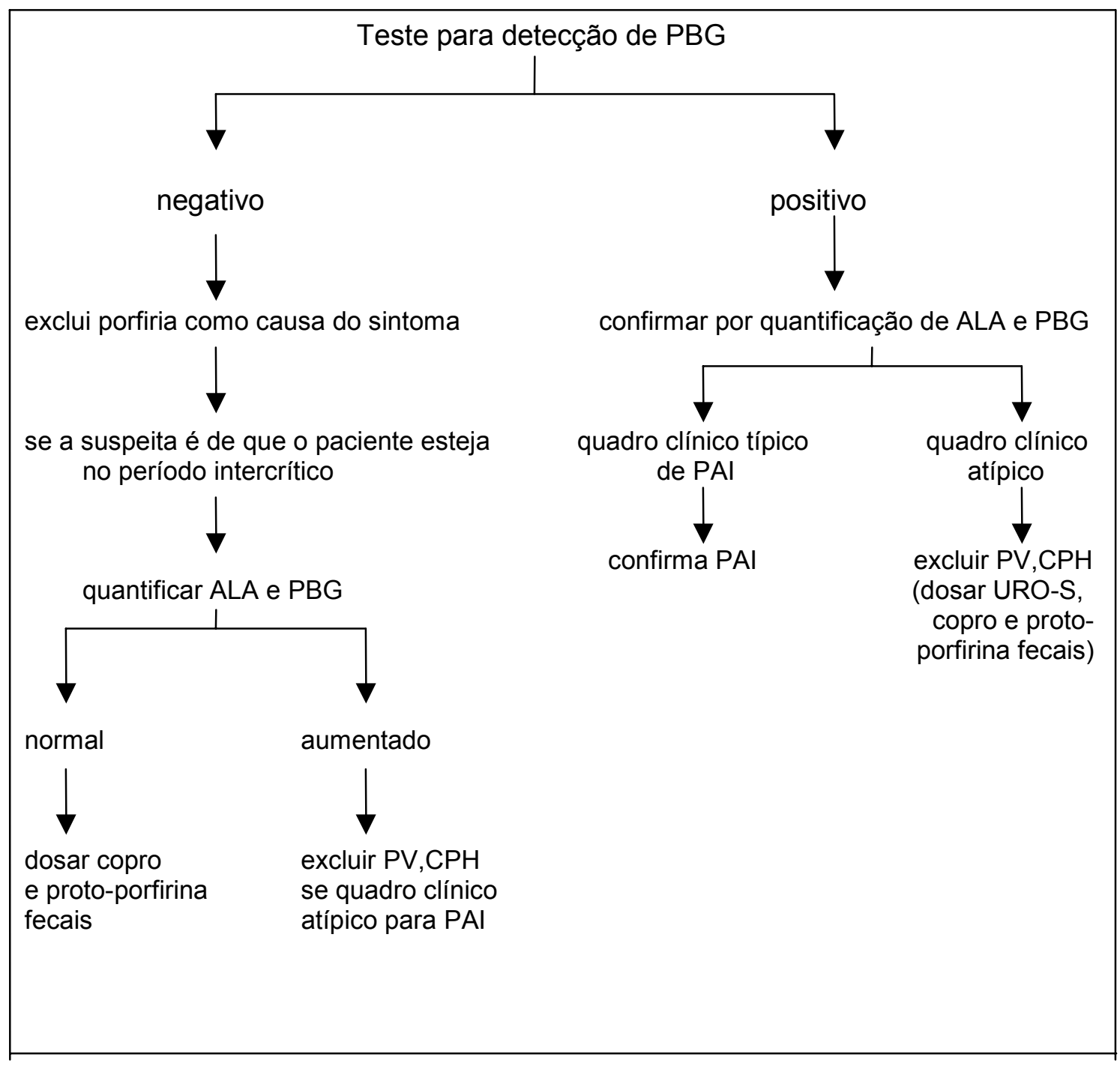

Figura 13- Algoritmo para diagnóstico de PAI. Esquema simplificado da seqüência de exames laboratoriais diante da suspeita de PAl e exclusão de outros tipos de porfirias em vista de manifestações abdominais, neurológicas ou psiquiátricas, acompanhadas ou não de lesões cutâneas.

Modificado de Hindmarsh, J.T. The porphyrias: recent advances. Clin. Chem. v. 32 , p. 1261,1986

Segundo BECKER e KRAMER ${ }^{15}$, haveria fundamentalmente duas condições nas quais o ALA é excretado em grandes quantidades na urina, além da PAl: a intoxicação por chumbo a tirosinemia hereditária. $\mathrm{Na}$ primeira, observamos em comum com a porfiria dor abdominal, obstipação, taquicardia, hipertensão arterial sistêmica, déficits motores, e encefalopatia. A grande semelhança entre os quadros de intoxicação pelo chumbo e de 
porfiria aguda intermitente sugerem que a etiopatogenia destas duas afecções tenha algo em comum. Bioquimicamente, isto verifica-se na grande excreção urinária de ALA, enquanto que as pesquisas genéticas realizadas indicam que talvez exista correlação entre dois dos alelos codificadores da enzima URO-S e uma maior suscetibilidade à intoxicação pelo $\mathrm{Pb}$, havendo necessidade de estudos mais aprofundados a este respeito ${ }^{85}$. Estas doenças podem ser diferenciadas pelas dosagens de chumbo sérico e da enzima deficitária, respectivamente. Na tirosinemia hereditária, a excreção urinária de PBG e de porfirinas é normal, em contraste com a PAI. Além destas afecções, a D-ALA-D também deve ser considerada como causa de eliminação de grandes quantidades de ALA na urina.

CRIMLISK $^{35}$ sugere que o diagnóstico de PAI deve ser considerado quando houver: 1) eventos psiquiátricos episódicos associados a: sintomas abdominais recorrentes inexplicados, alteração do nível de consciência ou confusão mental, histórico familiar de morte inexplicada ou de quadro psiquiátrico, ou que sejam temporalmente relacionados à menstruação ou induzidos pelo álcool; 2) diagnóstico psiquiátrico de: psicose resistente ao tratamento, desordem esquizoafetiva, psicose cíclica, distúrbio de conversão ou de somatisação, e síndrome da fadiga crônica; 3) diagnóstico diferencial das seguintes alterações neurológicas: encefalopatias, neuropatias motoras e sensitivo-motoras nas quais o quadro motor predomine, epilepsia refratária e enxaqueca. Poderíamos acrescentar a esta relação os pacientes submetidos a múltiplas intervenções exploratórias abdominais, sem achados cirúrgicos consistentes suficientes para explicar o quadro clínico. 
WATSON ${ }^{197}$ já havia descrito uma paciente submetida a 10 laparotomias até o momento do diagnóstico de porfiria, aos 30 anos de idade.

Em relação aos nossos resultados eletroneuromiográficos, dois foram realizados no mesmo serviço, e apenas um deles foi compatível com o descrito na literatura ${ }^{3,58}$, ou seja, demonstrou acometimento axonal com predomínio proximal nos quatro membros. O outro exame eletroneuromiográfico, normal, referia-se a uma paciente com tetraparesia discreta (força muscular grau IV), com quadro sensitivo caracterizado por parestesias nos quatro membros. Provavelmente as fibras de menor calibre foram as mais acometidas, já que o exame eletroneuromiográfico avalia apenas as fibras mais grossas. Não foi realizada biópsia de nervo nesta paciente. A terceira eletroneuromiografia, realizada em outro serviço, demonstrou padrão compatível com polimiosite, ou seja, sinais de desnervação abundantes, predominando na musculatura proximal dos quatro membros, com potenciais de amplitudes reduzidas. Não há relato neste exame quanto à presença de padrão de recrutamento paradoxal, o que pode nos levar a crer que ocorreu interpretação equívoca dos dados, já que a biópsia muscular foi compatível com acometimento neurogênico primário, resultado este de acordo com o diagnóstico de PAI, comprovado na paciente. Em nenhum caso avaliado eletroneuromiograficamente houve redução da velocidade de condução, motora ou sensitiva, ou alongamento dos tempos de latências, o que concorda com o observado por vários autores, pois se as velocidades de condução são normais, o distúrbio é primariamente axonal, e não desmielinizante. Isto reforça o conceito de que 
a lesão neuropatológica primária é axonal, o que não foi universalmente aceito no princípio dos estudos sobre esta doença.

Existem ainda dúvidas a respeito do mecanismo de lesão do nervo periférico. Como notaram CAVANAGH e MELLICK ${ }^{30}$, a degeneração parece ser do tipo "dying-back", embora o processo não se encontre restrito às fibras mais longas, e as fibras que inervam a musculatura proximal possam estar tão ou mais afetadas que as mais distais. O padrão de acometimento "dying-back" refletiria uma agressão metabólica difusa, onde as regiões mais distais seriam sempre mais ou as únicas a serem acometidas. RIDLEY ${ }^{154}$ sugere que os neurônios que inervam os músculos proximais, relacionados a unidades motoras maiores, sejam mais vulneráveis a alguns distúrbios metabólicos. Além disso, a especificidade da atividade exercida pelo grupo muscular também pode exercer alguma influência no grau de alteração observado, tomando-se como exemplo o acometimento mais acentuado dos músculos anti-gravitacionais ${ }^{153}$.

É altamente recomendável a detecção de portadores na família do paciente acometido, já que as crises podem ser prevenidas evitando-se fatores ou substâncias, como medicações, que habitualmente desencadeiam crises. Este objetivo é atualmente melhor atingido através de diagnóstico molecular $^{170}$. WALDENSTRÖM ${ }^{195}$, em 1957, já havia obtido redução considerável no número de óbitos pela doença, de 19 para 2, em duas décadas sucessivas, em uma família numerosa por ele estudada, pela simples identificação genotípica de seus membros. 


\subsubsection{Tratamento, Evolução e Prognóstico}

Na série estudada por KAUPPINEN e MUSTAJOKI ${ }^{91}$, menos de $14 \%$ dos episódios de PAI necessitaram de internação, embora mais de metade dos pacientes tenha relatado sintomas leves sugestivos de porfiria. Reconhece-se que sintomas de menor gravidade são mais freqüentes do que os mais graves, embora talvez a freqüência destes sintomas seja superestimada, pois em várias ocasiões eles podem ser atribuídos a outras condições que não a PAl, como por exemplo cólicas menstruais.

Um aspecto a ser realçado é a baixa taxa de mortalidade entre os pacientes com PAI nos pacientes aqui estudados (8,1\%), quando comparados a outros estudos. STEIN e TSCHUDY ${ }^{174}$ referem 10\%, enquanto que GOLDBERG ${ }^{66}, 24 \%$, e RIDLEY ${ }^{153}, 34,4 \%$. Numa série mais recente, DE SIERVI et al. ${ }^{42}$ em 20 anos, relatam $15 \%$ de mortalidade. JEANS et al. ${ }^{87}$, numa revisão de 50 anos, estudando a evolução de 136 pacientes que necessitaram de internação, relatam mortalidade de $20 \%$ no episódio inicial de $\mathrm{PAl}$, e $38 \%$ nos subseqüentes, avaliando que a mortalidade na população com PAI sintomática é três vezes a encontrada na população controle. A maior parte das mortes foi devida à própria crise porfírica, e cinco pacientes cometeram suicídio. Além disso, observaram também maior tempo de sobrevida no grupo de pacientes diagnosticados após 1971, ano em que a hematina tornou-se disponível. Esta redução significativa ao longo dos anos deve-se sem dúvida ao aprimoramento no diagnóstico, tornando-o precoce e ao melhor conhecimento de fatores 
desencadeantes das crises e da profilaxia necessária nos portadores. A efetividade do tratamento em si, com melhores condições de suporte ventilatório, e a evolução observada na condução da terapêutica na crise, realçando-se a importância do aumento do aporte de carboidratos, eventualmente utilizando-se hematina e, quando possível, heme arginato, também foram fundamentais na melhora do prognóstico. A associação de aporte de altas quantidades de glicose e hematina mostrou-se mais eficaz do que o uso de cada uma delas separadamente ${ }^{96}$. Profilaticamente, podese evitar a recorrência dos ataques com maior ingestão de carboidratos, e, especificamente nas mulheres, com terapias hormonais supressoras da ovulação. Provavelmente, a futura ampliação da disponibilidade do diagnóstico molecular da doença conduzirá a um menor número de crises nos pacientes, já que a detecção precoce do portador fará com que os fatores precipitantes sejam evitados, conforme foi demonstrado na literatura por KAUPPINEN e MUSTAJOKI ${ }^{91}$.

Em relação à associação de PAl com outras afecções, que também são fatores determinantes na sobrevida, observou-se na literatura maior incidência de hepatocarcinoma, e na casuística de KAUPPINEN e MUSTAJOKI $^{91}$, foi causa de morte em $8,3 \%$ dos pacientes. A insuficiência renal crônica e a hipertensão arterial sistêmica também foram observadas com maior freqüência na PAl do que na população geral. Em relação à hipertensão, notou-se que, em mulheres que haviam apresentado ao menos uma crise de PAI, ela manifestou-se mais freqüente e precocemente que no grupo controle ${ }^{96}$. Estes dados não foram obtidos na nossa série, sendo 
necessário acompanhamento a longo prazo de um número significativo de doentes e comparação com grupo controle.

A quantificação do PBG excretado na urina parece ter implicações importantes no prognóstico do paciente, na medida em que, segundo os autores acima citados, a recorrência de crises tem relação direta com os níveis de precursores urinários, o que significa que os portadores do defeito genético, sintomáticos ou não, que eliminam pequenas quantidades de PBG, provavelmente terão menos crises do que aqueles nos quais a excreção de PBG é maior. Desta forma, delineia-se certa previsibilidade na ocorrência das crises em determinados indivíduos, o que pode ter implicações importantes quando da necessidade de usar-se ou não determinada medicação a princípio contra-indicada, ou de optar por um procedimento cirúrgico. Resta saber se a quantidade de precursor excretado teria relação com a gravidade da crise.

Notamos que $17,1 \%$ das crises por nós analisadas receberam algum tipo de tratamento específico, que visasse atuar na fisiopatologia da doença, como a hematina e o EDTA. Não é possível realizar com estes dados uma avaliação crítica a respeito da eficácia dos tratamentos instituídos, visto que não dispomos de dados a respeito do tratamento de todos os pacientes. É curioso notar que o EDTA tem o efeito de induzir a atividade da ALA-S ${ }^{89}$, o que seria contrário à ação terapêutica desejada em crises de PAl. Não há relatos na literatura de tratamento de crises de PAl com outros agentes quelantes, como o mesilato de deferoxamina, específico do ferro, ou com outros anti-oxidantes, como a $n$-acetil-cisteína. 


\subsubsection{DOENÇAS ASSOCIADAS}

Não encontramos neste estudo nenhuma doença diretamente relacionada à PAI. Algumas destas condições, porém, indiretamente, podem atuar como facilitadoras da crise, seja pela própria natureza da doença ou pelo tratamento da mesma, como endometriose, abortamento habitual, irregularidade menstrual, amenorréia, cistites de repetição, e epilepsia. Em três pacientes observamos distúrbios psiquiátricos, como hiperatividade (na criança), claustrofobia, e depressão. Na paciente com distúrbio depressivo, encontra-se alguma dificuldade em caracterizar o quadro como causa ou como conseqüência da PAI, assim como na paciente com abortamento habitual. A conduta ideal seria a dosagem dos precursores na urina durante estes episódios, para que fosse estabelecido se estes podem ser considerados como sintomas das crises de porfiria, ou apenas como fatores coadjuvantes. Hipertensão arterial sistêmica foi encontrada em $8,1 \%$ dos pacientes. Não há nenhum paciente com diabete melito, o que corrobora uma observação interessante feita por ANDERSSON et al. ${ }^{6}$, a respeito de uma suposta melhora ou fim das crises de PAl que seria observada quando o paciente torna-se diabético, observada em 16 de seus pacientes, explicada pela característica peculiar do metabolismo destes doentes em relação aos carboidratos. 
6. CONCLUSÕES 
1. A PAI manifestou-se mais freqüentemente no sexo feminino, e este grupo também teve maior número de crises por paciente. A maioria dos surtos agudos, assim como a primeira crise, ocorreu na terceira década de vida.

2. Os aspectos clínicos mais freqüentemente observados na PAI, nesta ordem, são: dor abdominal, alteração da cor da urina, mudança do ritmo intestinal, déficit motor ou sensitivo-motor, vômitos, alteração do nível de consciência ou confusão mental, insuficiência respiratória, crises convulsivas, hipertensão e taquicardia, e quadros psiquiátricos.

3. A tríade clássica dor abdominal, alterações neurológicas e psiquiátricas ocorreu apenas em $9,5 \%$ das crises. Ainda mais raramente a apresentação destas três manifestações foi concomitante, sendo de pouco auxílio diagnóstico em fases precoces do surto.

4. A neuropatia periférica foi aguda, nos quatro membros, sensitiva e motora, de predomínio motor e proximal, e de padrão axonal. É relativamente específica, comportando poucos diagnósticos diferenciais.

5. As formas crônicas foram identificadas em $35,1 \%$ dos pacientes, cujas manifestações clínicas foram sempre de menor gravidade, como dor abdominal, alteração da cor da urina, e, menos freqüentemente, por quadros psiquiátricos, como depressão. 
7. ANEXO 
ANEXO A- EFEITO DAS DROGAS EM RELAÇÃO ÀS CRISES DE PAI

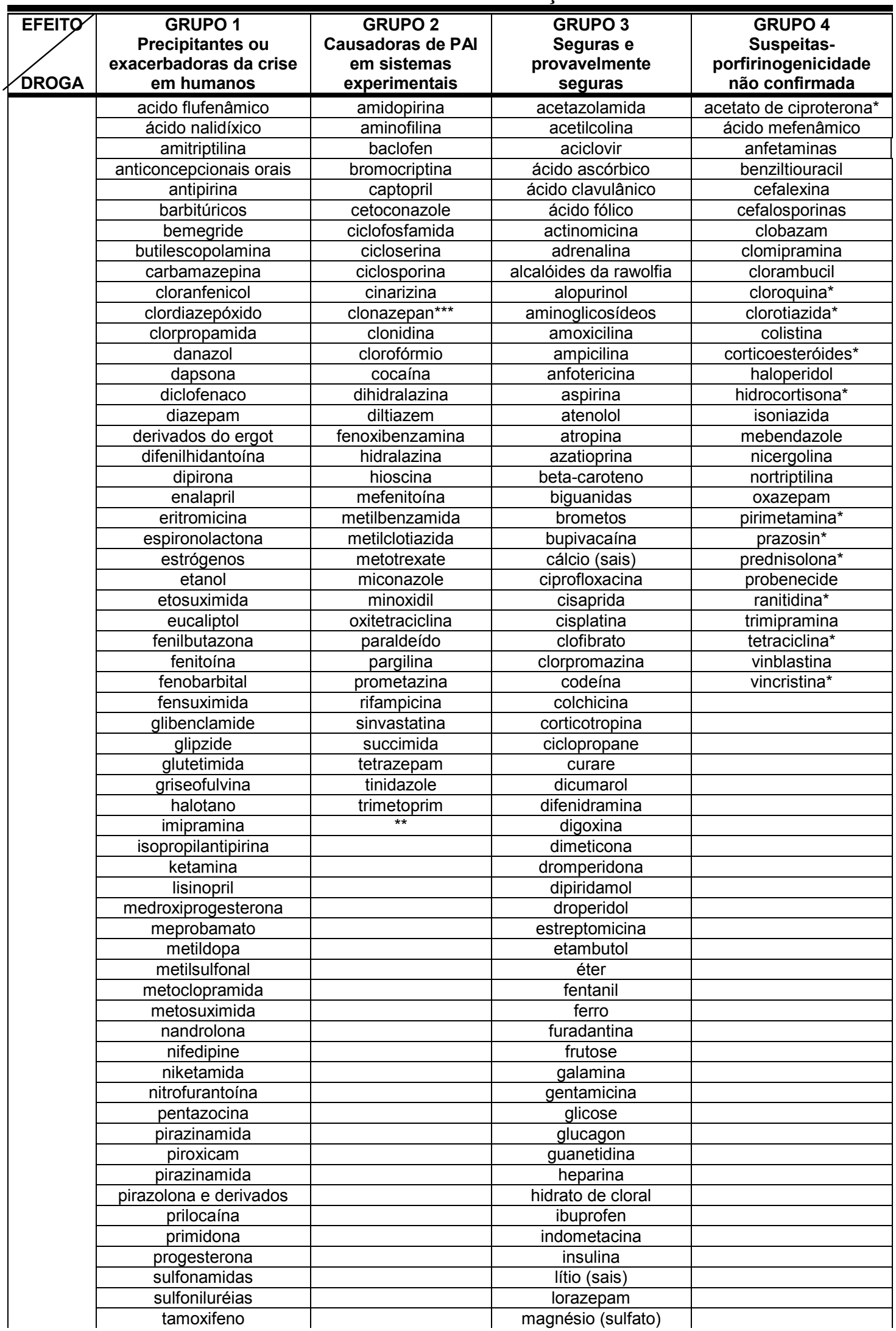




\begin{tabular}{|c|c|c|c|c|}
\hline EFEITQ & $\begin{array}{c}\text { GRUPO 1 } \\
\text { Precipitantes ou } \\
\text { exacerbadoras da crise } \\
\text { em humanos }\end{array}$ & $\begin{array}{c}\text { GRUPO 2 } \\
\text { Causadoras de PAI } \\
\text { em sistemas } \\
\text { experimentais }\end{array}$ & $\begin{array}{c}\text { GRUPO 3 } \\
\text { Seguras e } \\
\text { provavelmente } \\
\text { seguras }\end{array}$ & $\begin{array}{c}\text { GRUPO 4 } \\
\text { Suspeitas- } \\
\text { porfirinogenicidade } \\
\text { não confirmada }\end{array}$ \\
\hline & teofilina e derivados & & meperidina & \\
\hline & tiopentona & & metadona & \\
\hline & tolbutamida & & metformim & \\
\hline & troxidone & & mianserin & \\
\hline & valproato & & $\begin{array}{c}\text { monofosfato de } \\
\text { adenosina }\end{array}$ & \\
\hline & verapamil & & morfina e derivados & \\
\hline & vibramicina & & nadolol & \\
\hline & & & neostigmine & \\
\hline & & & norfloxacina & \\
\hline & & & oxitocina & \\
\hline & & & óxido nitroso & \\
\hline & & & paracetamol & \\
\hline & & & penicilina & \\
\hline & & & pizotifeno & \\
\hline & & & procaína & \\
\hline & & & promazina & \\
\hline & & & propiltiouracil & \\
\hline & & & propoxifeno & \\
\hline & & & propranolol & \\
\hline & & & prostigmina & \\
\hline & & & quinidina & \\
\hline & & & quinina & \\
\hline & & & reserpina & \\
\hline & & & salbutamol & \\
\hline & & & sorbitol & \\
\hline & & & succinilcolina & \\
\hline & & & triazolam & \\
\hline & & & trifluoperazina & \\
\hline & & & vancomicina & \\
\hline & & & vitaminas $a, b, c, d, e$ & \\
\hline & & & warfarin & \\
\hline & & & zidovudina & \\
\hline & & & $\begin{array}{c}\text { zinco (preparações } \\
\text { tópicas) }\end{array}$ & \\
\hline
\end{tabular}

* Relatos conflitantes de porfirinogenicidade experimental; na maioria das vezes não precipitantes, ocasionalmente positivas. Nenhuma destas drogas foi relacionada a ataques de porfiria em humanos

** Todas as drogas que induzem o citocromo $\mathrm{P}_{450}$ ou que aumentam o "turnover" do heme hepático

${ }^{* * *}$ Em altas doses

Modificado de MOORE, M.R.; HIFT, J.R. Drugs in the acute porphyrias-toxicogenetic diseases. Cell. Mol. Biol. v. 43, p. 89-94, 1997 


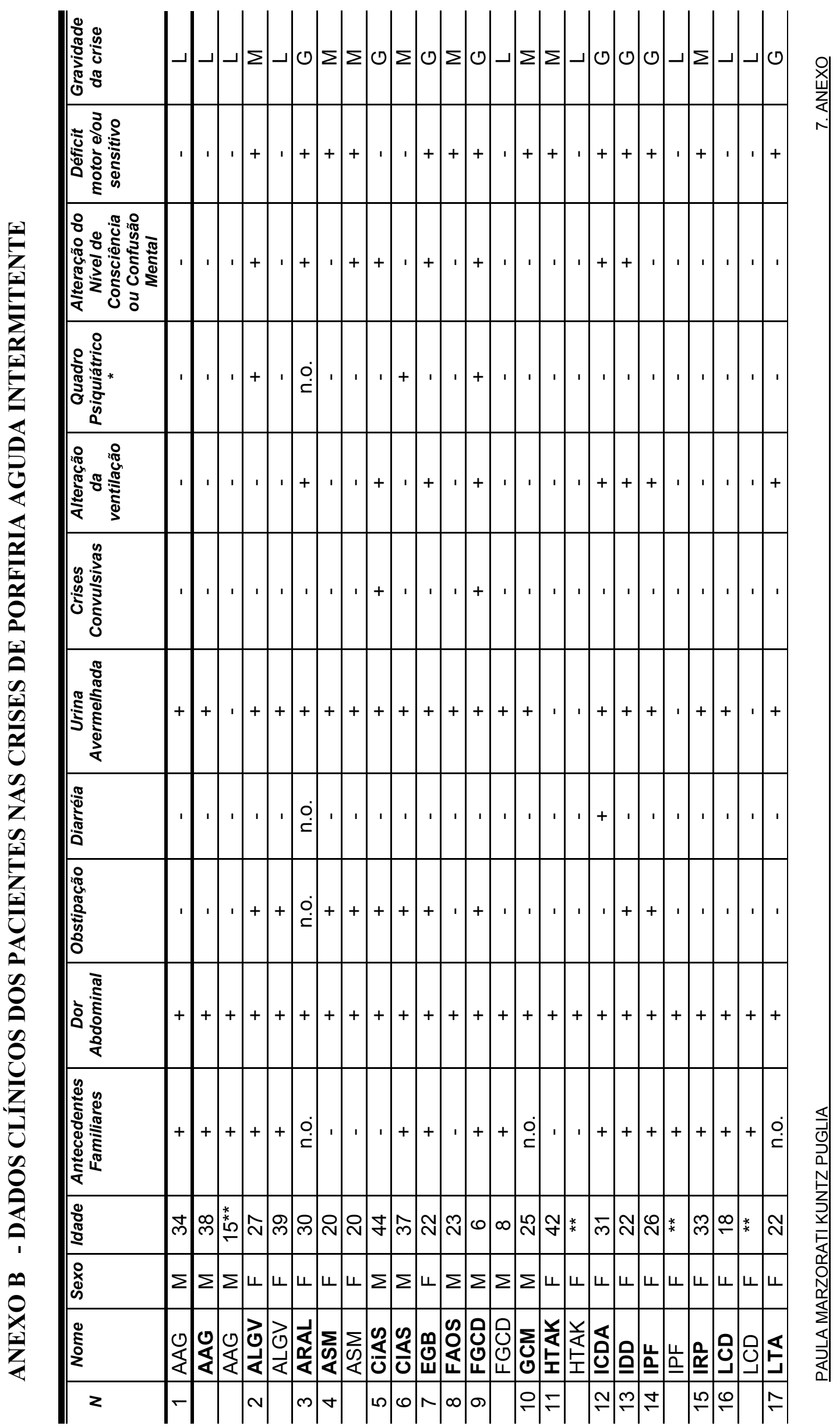




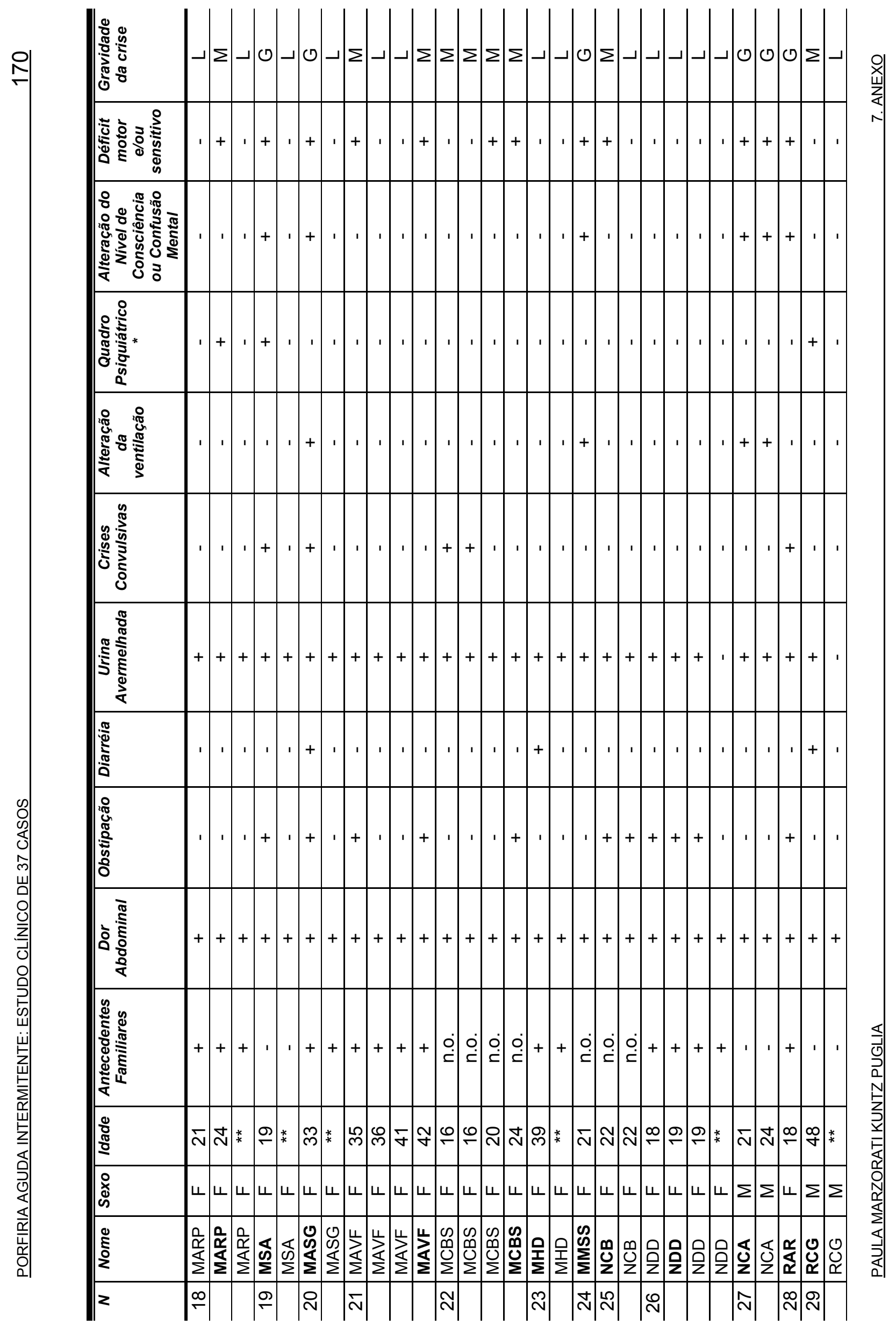




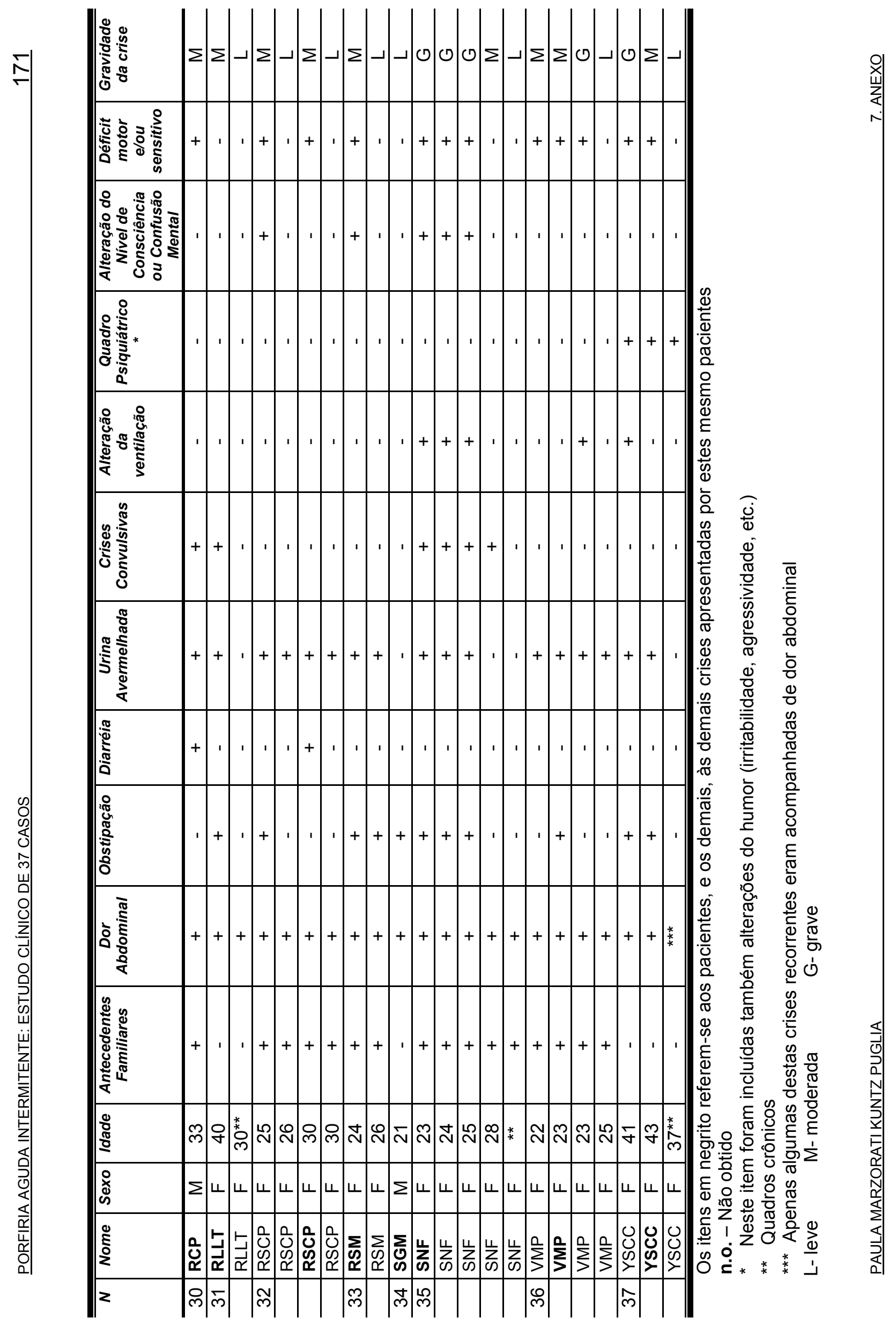




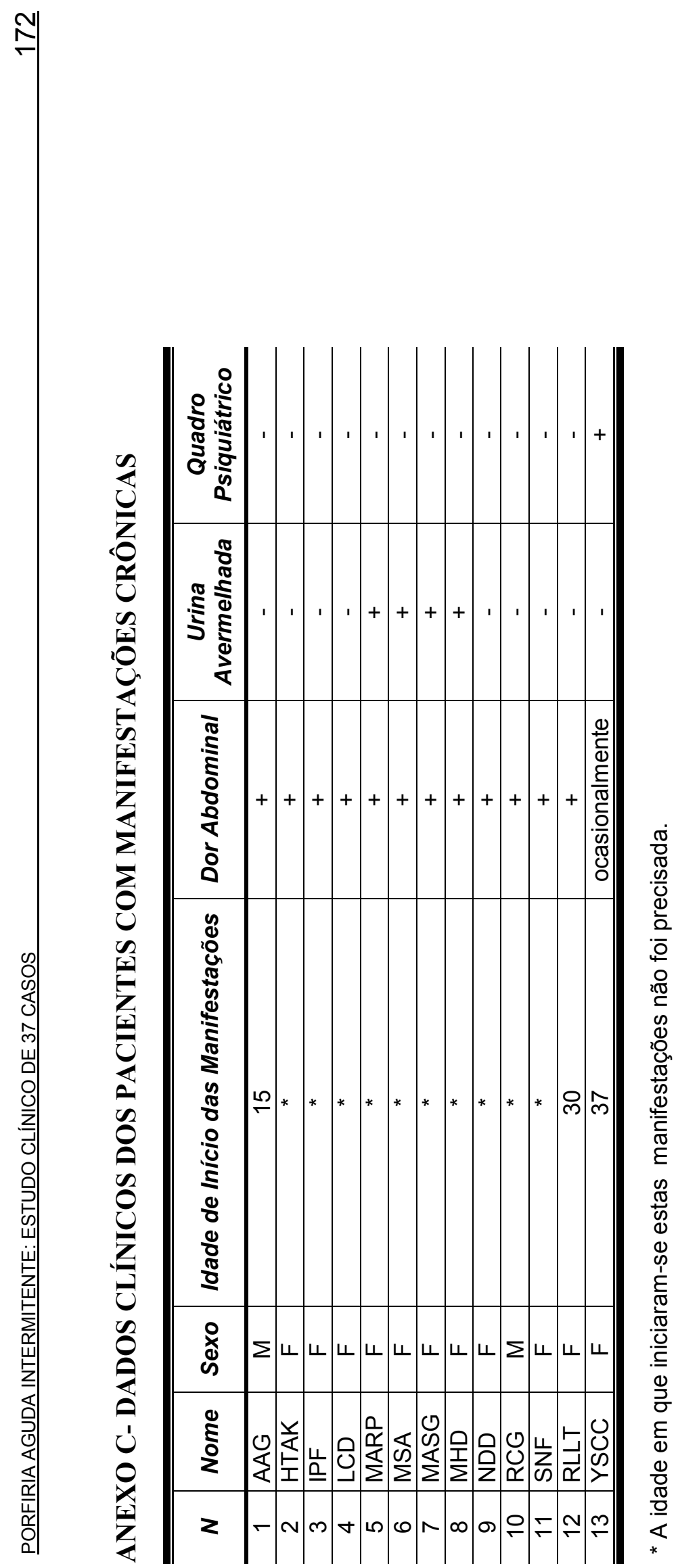




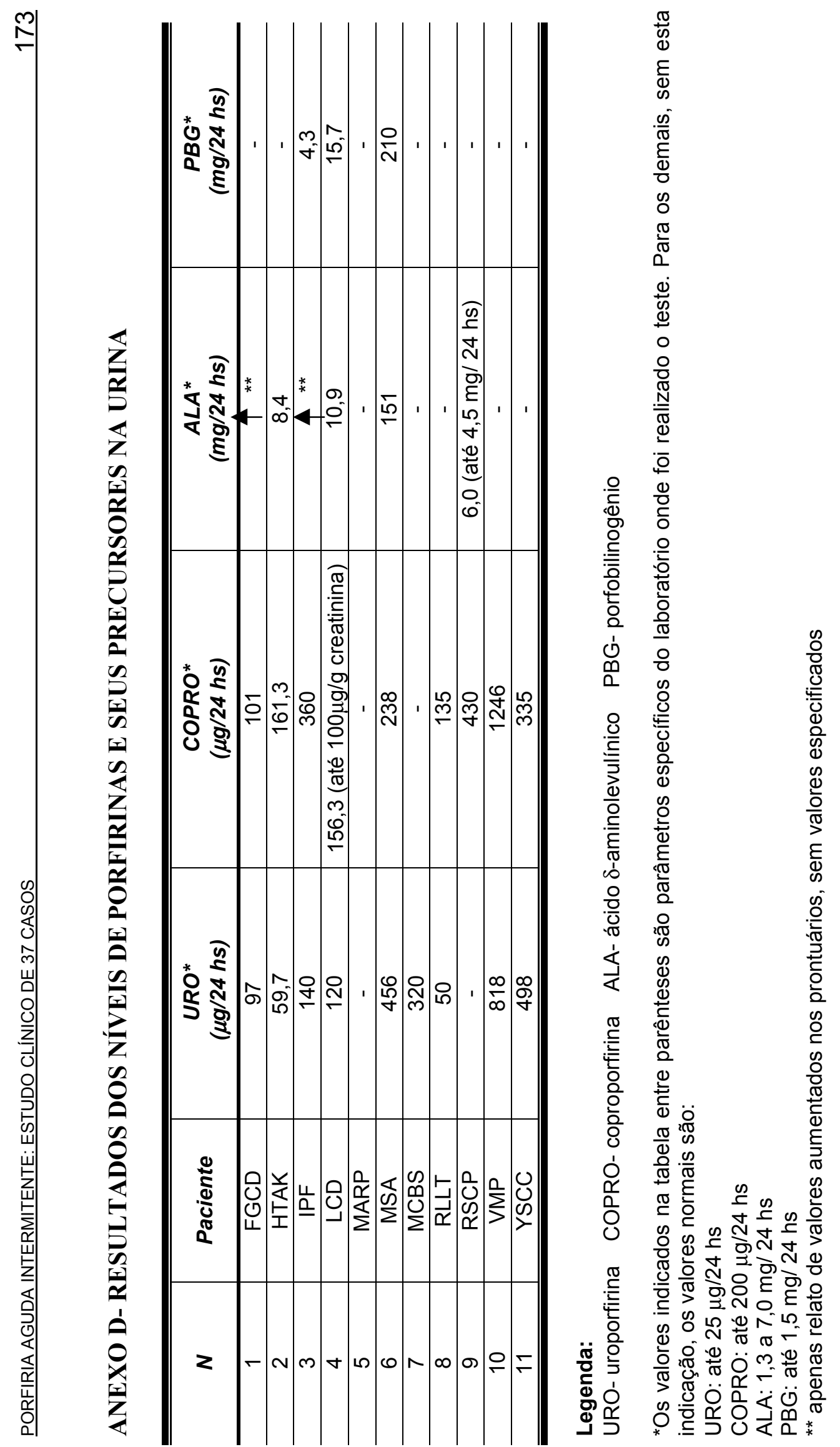









\section{ANEXO F- PROTOCOLO: PORFIRIA AGUDA INTERMITENTE}

1) Número da ficha:

2) Nome:

3) Registro:

4) Sexo:

5) Idade:

Data da Alta:

Naturalidade:

Profissão:

6) Quantos episódios prévios semelhantes ao atual ou cujos quadros clínicos podem ser atribuídos à PAI (data dos episódios)

7) Quadro clínico dos episódios anteriores (número da ficha):

8) Antecedente familiar conhecido de porfiria: $\mathrm{S} \_$____ Número

9) Outras doenças:

10) Cirurgias anteriores e relativas aos episódios de porfiria:

11) Fatores precipitantes nos episódios (jejum, cirurgia, medicamentos, estresse, outros):

12) Quadro clínico do episódio atual:

a) Pródromo? S_ N Q N $\quad \mathrm{N}$ _

b) Dor abdominal (característica, duração e localização):

c) Mudança da cor da urina? $\mathrm{S}$

d) Obstipação: $\mathrm{S} \quad \mathrm{N} \quad$ Diarréia: $\mathrm{S}$

e) Crises convulsivas: $S_{-} \quad \mathrm{N} \quad$ Generalizada_ Focal

f) Alteração do padrão de sono ou pesadelos?

g) Alteração do nível de consciência:

h) Quadro psiquiátrico:

i) Neuropatia periférica: $\mathrm{S}$

4 membros membros inferiores mononeurite membros superiores

Motora Sensitivo-motora

Sensitiva

Predomínio: Proximal Distal

Descrição:

13) Exame neurológico:

a) Reflexos profundos:

Direita: Bicipital: abolido

Esquerda: Bicipital: abolido

Direita: Patelar: abolido

Esquerda: Patelar: abolido

Direita: Aquileu: abolido

Esquerda: Aquileu: abolido

b) Cutâneo plantar:

Direita: flexão_ extensão___ Esquerda: flexão

$\begin{array}{ll}\text { presente_ } & \text { hipoativo } \\ \text { presente_ } & \text { hipoativo }\end{array}$

presente_ hipoativo

presente_ hipoativo

presente_ hipoativo

presente_ hipoativo

c) Sensibilidade superficial (localização):

Hipoestesia

Parestesia

d) Sensibilidade profunda: Normal

e) Nervos Cranianos (descrição) 
f) Bexiga neurogênica: 14) Eletroneuromiografia:

$S$

-

Descrição:

15) Exames Complementares:

a) Reação Watson-Schwartz: positiva

b) Dosagem ALA:

c) Dosagem PBG:

d) Dosagem URO:

e) Dosagem COPRO:

f) Dosagem $\mathrm{Na}$ e K:

g) Glicemia:

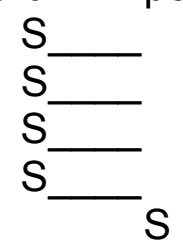

h) Dosagem de hemoglobina e leucócitos: Valor

i) Líquor $\mathrm{S} \quad \mathrm{N} \quad$ células

j) Ressonância Magnética de encéfalo

I) Estudo Genético

m) Outros

16) Tratamento da Crise:

a) Dieta rica em carboidratos $S$

b) Infusão de glicose hipertônica $S$

c) Beta-bloqueador

d) Neuroléptico

e) Codeína

f) Hematina

g) EDTA



Valor negativa
Valor
Valor
Valor
Valor
Valor

h) Outros

17) Evolução:
a) Melhora
total
parcial

b) Piora

c) Óbito

d) Seqüela

$\mathrm{N}$

$\mathrm{N}$

$\mathrm{N}$

$\mathrm{N}$

N

$\mathrm{N}$

$\mathrm{N}$ proteína

$\mathrm{S}$

$S$

$S$

$\mathrm{S}$
N 
8. REFERÊNCIAS BIBLIOGRÁFICAS 
1. ADAMS, R.D.; DENNY-BROWN, D.; PEARSON, C.M. Spinal and neural muscular atrophies. In Diseases of muscle. A study in pathology. $1^{\text {a. }}$ ed., Londres, Cassell and Co. Ltd., 1953, cap. 10, p. $433-5$

2. ADAMS, R.D.; VICTOR, M.; ROPPER, A.H. The inherited metabolic diseases of the nervous system. In Principles of Neurology. $6^{\text {a }}$ ed., New York, McGraw-Hill Co., 1997, cap. 37, p. 953

3. ALBERS, J.W.; ROBERTSON, W.C.; DAUBE, J.R. Electrodiagnostic findings in acute porphyric neuropathy. Muscle Nerve v. 1, p. 2926,1978

4. ANDERSON, K.E.; BRADLOW, H.L.; SASSA, S.; KAPPAS, A. Relationship of the $5 \alpha$-reductive metabolism of steroid hormones to clinical expression of the genetic defect in acute intermittent porphyria. Am. J. Med. v. 66, p. 644-50, 1979

5. ANDERSON, P.M.; REDDY, R.M.; ANDERSON, K.E.; DESNICK, R.J. Characterization of the PBG-deaminase deficiency in acute intermittent porphyria. I. Immunological evidence for heterogeneity of the genetic defect. J. Clin. Invest. v. 68, p. 1-12, 1981

6. ANDERSSON, C.; BYLESJÖ, I.; LITHNER, F. Effects of diabetes mellitus in patients with acute intermittent porphyria. J. Intern. Med. v. 245, p. 193-7, 1999

7. ANZIL, A.P.; DOZIC, S. Peripheral nerve changes in porphyric neuropathy: findings in a sural nerve biopsy. Acta Neuropathol. v.42, p.121-6, 1978 
8. ASSIS, J.L.; JULIÃO, Fo․; CARVALHO F 으, E.T. Porfiria aguda intermitente: estudo de seis casos. Rev. Paul. Med. v. 64, p. 4156,1964

9. BADAWY, A.A.; EVANS, M. Alcohol addiction, porphyria, and mental disorders. Lancet v. 2, p. 374-5, 1972

10. BAKER, A.B.; WATSON, C.J. The central nervous system in porphyria. J. Neuropathol. Exp. Neurol. v. 4, p. 68-76, 1945

11. BARCLAY, N. Acute intermittent porphyria in childhood: a neglected diagnosis? Arch. Dis. Child. v. 49, p. 404-5, 1974

12. BEATTIE, A.D.; GOLDBERG, A. Acute intermittent porphyria: Natural history and prognosis. In Doss $\mathrm{M}$, ed. Porphyrins and Human Disease. Basel, Switzerland, S Karger, 1976, p. 245, apud KAPPAS et al., 1983

13. BECHARA, E.J.H. Oxidative stress in acute intermittent porphyria and lead poisoning may be triggered by 5 -aminolevulinic acid. Braz. J. Med. Biol. Res. v. 29, p. 841-51, 1996

14. BECHARA, E.J.H.; MEDEIROS, M.H.G.; MONTEIRO, H.P.; HERMES-LIMA, M.; PEREIRA, B.; DEMASI, M.; COSTA, C.A.; ABDALLA, D.S.P.; ONUKI, J.; WENDEL, C.M.A.; DI MASCIO, P. A free radical hypothesis of lead posioning and inborn porphyrias associated with 5-aminolevulinic acid overload. Química Nova v. 16 , p. $297-304,1993$

15. BECKER, D.M.; KRAMER, S. The neurological manifestations of porphyria: a review. Medicine v. 56, p. 411-23, 1977 
16. BERLIN, L.; COTTON, R. Gastro-intestinal manifestations of porphyria Amer. J. Digest. Dis. v. 17, p.110-4, 1950

17. BERMÚDEZ-MORETTI, M.; CORREA-GARCIA, S.; RAMOS, E.; BATTLE, A. Delta-aminolevulinic acid uptake is mediated by the gamma-aminobutyric acid-specific permease UGA 4. Cell. Mol. Biol. v.42, p. 519-23, 1996

18. BIEMPICA, L.; KOSOWER, N.; MA, M.H.; GOLDFISCHER, S. Hepatic porphyrias. Arch. Pathol. v. 98, p. 336-43, 1974

19. BLACK, K.S.; MIRSKY, P.; KALINA, P.; GREENBERG, R.W.; DREHOLB, K.E.; SAPAN, M.; MEIKLE, E. Angiographic demonstration of reversible cerebral vasospasm in porphyric encephalopathy. AJNR v. 16, p. 1650-52, 1995

20. BLOM, H; ANDERSSON, C.; OLOFSSON, B.O.; BJERLE, P.; WIKLUND, U.; LITHNER, F. Assessment of autonomic nerve function in acute intermittent porphyria: A study based on spectral analysis of heart rate variability. J. Int. Med. v. 240, p.73-9, 1996

21. BLOOMER, J.R. The hepatic porphyrias: pathogenesis, manifestations, and management. Gastroenterology v.71, p. 689701,1976

22. BONKOVSKY, H.L.; SCHADY, W. Neurologic manifestation of acute porphyria. Semin. Liver Dis. v.2, 108-24, 1982

23. BONKOVSKY, H.L.; TSCHUDY, D.P.; COLLINS, A.; DOHERTY, J.; BOSSENMAIER, I.; CARDINAL, R.; WATSON, C.J. Repression of 
the overproduction of porphyrin precursors in acute intermittent porphyria by intravenous infusions of hematin. Proc. Natl. Acad. Sci. v. 68 , p. $2725-9,1971$

24. BONT, A.; STECK, A.J.; MEYER, U.A. Die akuten hepatischen Porphyrien und ihre neurologischen Syndrome. Schweiz Med. Wschr. v. 126, p. 3-14, 1996

25. BOSCH, E.P.; PIERACH, C.A.; BOSSENMAIER, I.; CARDINAL, R.; THORSON, M. Effect of hematin in porphyric neuropathy. Neurology v.27, p.1053-6, 1977

26. BRENNAN, M.J.W.; CANTRILL, R.C. $\delta$-Aminolaevulinic acid is a potent agonist for GABA autoreceptors. Nature v. 280, p. 514-5, 1979

27. BYLESJÖ, I.; FORGSGREN, L.; LITHNER, F.; BOMAN, K. Epidemiology and clinical characteristics of seizures in patients with acute intermittent porphyria. Epilepsia v.37, p. 230-5, 1996

28. CAMPBELL, K. A case of hematoporphyrinuria. J. Ment. Sci. v. 44, p. 305-313, 1898, apud YEUNG-LAIWAH et al., 1987, p. 377

29. CARNEY, M.W.P. Hepatic porphyria with mental symptoms - Four missed cases. Lancet v. 2, p. 100-1, 1972

30. CAVANAGH, J.B.; MELLICK, R.S. On the nature of peripheral nerve lesions associated with acute intermittent porphyria. J. Neurol. Neurosur. Psychiat. v. 28, p.320-7, 1965 
31. ChAIX, Y.; GENCOURT, C.; GROUTEAU, E.; CARRIËRE, J.P. Porphyrie aigüe intermittente et épilepsie chez un même enfant: difficultés diagnostiques et thérapeutiques. Arch. Pédiatr. v. 4, p. 971-4, 1997

32. CHAUDHRY, M.R. Meningism, pericarditis/myocarditis unrecognised manifestations of acute porphyria. JPMA v. 36, p. 239-43, 1986

33. COHEN, P.H.; HADLER, N.M.; STARKENBURG, R. Acute intermittent porphyria presenting as acute muscle pain, fever, and weakness. Arthritis \& Rheumatism v. 40, p. 586-7, 1997

34. COSTA, C.A.; TRIVELATO, G.C.; PINTO, A.M.P.; BECHARA, E.J.H. Correlation between plasma 5 -aminolevulinic acid concentrations and indicators of oxidative stress in lead-exposed workers. Clin. Chem. v. 43, p. 1196-202, 1997

35. CRIMLISK, H.L. The little imitator-porphyria: a neuropsychiatric disorder. J. Neurol. Neurosurg. Psychiatr. v. 62, p.319-28, 1997

36. CROSS, T.N. Porphyria - a deceptive syndrome. Am. J. Psychiatry v. 112, p. 1010-4, 1956

37. DANIELL, W.E.; STOCKBRIDGE, H.L.; LABBE, R.F.; WOODS, J.S.; ANDERSON, K.E.; BISSEL, D.M.; BLOOMER, J.R.; ELLEFSON, R.D.; MOORE, M.R.; PIERACH, C.A.; SCHREIBER, W.E.; TEFFERI, A.; FRANKLIN, G.M. Environmental chemical exposures and disturbances of heme synthesis. Environ. Health Perspect. v. 105, p.37-53, 1997 
38. DE BLOCK, C.E.M.; LEEUW, I.H.; GAAL, L.F.V. Premenstrual attacks of acute intermittent porphyria: hormonal and metabolic aspects- a case report. Eur. J. Endocrinol. v. 141, p. 50-4, 1999

39. DE FRANCISCO, M.; SAVINO, P.J.; SCHATZ, N.J. Optic atrophy in acute intermittent porphyria. Am. J. Ophtalmol. v. 87, p. 221-4, 1979

40. DE MATTEIS, F.; MARKS, G.S. Cytochrome $P_{450}$ and its interactions with the heme biosynthetic pathway. Can. J. Physiol. Pharmacol. v. 74, p. $1-8,1996$

41. DEMASI, M.; PENATTI, C.A.A.; DELUCIA, R; BECHARA, E.J.H. The prooxidant effect of 5-aminolevulinic acid in the brain tissue of rats: Implications in neuropsychiatric manifestations in porphyrias. Free Radic. Biol. Med. v. 20, p.291-9, 1996

42. DE SIERVI, A.; ROSSETTI, M.V.; PARERA, V.E.; MENDEZ, M.; VARELA, L.S.; BATLLE, A.M.C. Acute intermittent porphyria: Biochemical and clinical analysis in the argentinean population. Clin. Chem. Acta v. 288, p. 63-71, 1999

43. DESNICK, RJ; OSTASIEWICZ, LT; TISHLER, PA; MUSTAJOKI, P. Acute intermittent porphyria: characterization of a novel mutation in the structural gene for porphobilinogen deaminase. Demonstration of noncatalytic enzyme intermediates stabilized by bound substrate. J. Clin. Invest. v. 76, p. 865-74, 1985

44. DHAR, G.J.; BOSSENMAIER, I.; CARDINAL, R.; PETRYKA, Z.J.; WATSON, C.J. Transitory renal failure following rapid PAULA MARZORATI KUNTZ PUGLIA 8. REFERÊNCIAS BIBLIOGRÁFICAS 
administration of a relatively large amount of hematin in a patient with acute intermittent porphyria in clinical remission. Acta Med. Scand. v. 203, p. 437-43, 1978

45. DIXON, B. Encephalopathy due to hyponatremia in acute intermittent porphyria. J. R. Soc. Med. v. 90, p. 500-1, 1997

46. DOUKI, T.; ONUKI, J.; MEDEIROS, M.H.G.; BECHARA, E.J.H.; CADET, J.; DIREITO MASCIO, P. DNA alkylation by 4,5dioxovaleric acid, the final oxidation product of 5 -aminolevulinic acid. Chem. Res. Toxicol. v. 11, p. 150-7, 1998

47. EALES, L. Acute porphyria: The precipitating and aggravating factors. S. Afr. J. Lab. Clin. Med. v. 17, p. 120-5, 1971

48. EALES, L.; LEVEY, M.J.; SWEENEY, G.D. The place of screening tests and quantitative investigations in the diagnosis of the porphyrias with particular reference to variegate and symptomatic porphyria. S. Afr. Med. J. v. 40, p. 63-71, 1966

49. EALES, L.; LINDER, G.C. Porphyria-the acute attack. An analysis of 80 cases. S. Afr. Med. J. v. 36, p. 284-92, 1962

50. ELDER, G.H. Hepatic porphyrias in children. J. Inher. Metab. Dis. v. 20, p. 237-46, 1997

51. ELDER, G.H. Update on enzyme and molecular defects in porphyria. Photodermatol. Photoimmunol. Photomed. v. 14, p. 66-9, 1998 
52. ERBSLÖH, W. Zur pathologie und pathologischen Anatomie der Toxischen Polyneuritis nach Sulfonalgebrauch. Dtsch. Z. Nervenkr. v.23, p.197-204, 1903

53. ESTROV, Y.; SCAGLIA, F.; BODAMER, A.F. Psychiatric symptoms of inherited metabolic disease. J. Inher. Metab. Dis. v. 23, p. 2-6, 2000

54. FELDMAN, D.S.; LEVERE, R.D.; LIEBERMAN, J.S.; CARDINAL, R.A.; WATSON, C.J. Presynaptic neuromuscular inhibition by porphobilinogen and porphobilin. Proc. Natl. Acad. Sci. v. 68, p. 383-6, 1971

55. FELSHER, B.F.; REDEKER, A.G. Acute intermittent porphyria: Effect of diet and griseofulvin. Medicine v. 46, p. 217-23, 1967

56. FERRARO-HERRERA, A.S.; KERN, H.B.; NAGLER, W. Autonomic disfunction as the presenting feature of Guillain-Barré Syndrome. Arch. Phys. Med. Rehabil. v. 78, p. 777-9, 1997

57. FISCHER, H. Über das Kotporphyrin. Ztschr. Physiol. Chem. v.96, p.148-182, 1915, apud WATSON, 1966, p.127

58. FLÜGEL, K.A.; DRUSCHKY, K.F. Electromyogram and nerve conduction in patients with acute intermittent porphyria. J. Neurol. v. 214 , p. $267-79,1977$

59. FRANKE K.; FIKENTSCHE, R. Die Bedeutung der quantitativen porphyrin bestimmung mit der Lumineszenzmessung für die prufung der Leberfuktion und für Ernährungsfragen. München. 
Med. Wochenschr. v. 82, p. 171-2, 1935, apud MOORE, 1998, p. 215

60. FRÈRE, T.; ROY-PEAUD, F.; RIPAULT, M-P; DUMAS, P.; SILVAIN, C.; POURRAT, O.; BEAUCHANT, M. Porphyrie aiguë intermittente associée à un hyperaldostéronisme et à un syndrome de sécrétion inappropriée d'hormone anti-diurétique. Gastroenterol. Clin. Biol. v. 22 , p. $727-31,1998$

61. FRESSINAUD, C. Porphyries. In BOUCHE, P.; VALLAT, J-M., ed. Neuropathies Périphériques. $1^{\mathrm{a}}$ ed., Paris, Doin,1992, p. 607-18

62. GALBRAITH, R.A.; KAPPAS, A. Tin porphyrins decrease urinary excretion of haem pathway intermediates in patients with acute intermittent porphyria. Mol. Aspects Med. v.11, p. 61, 1990

63. GARCIN, R.; LAPRESLE, J. Manifestations nerveuses de la porphyrie. Semin. Hôp. Paris, v.26, p. 3404-23, 1950

64. GAZZANIGA, V. Uroporphyria: Some notes on its ancient historical background. Am. J. Nephrol. v. 19, p. 159-62, 1999

65. GIBSON, J.B.; GOLDBERG, A. The neuropathology of acute porphyria. J. Path. Bact. v. 71, p. 495 - 510, 1956

66. GOLDBERG, A. Acute intermittent porphyria. A study of 50 cases. Quart. J. Med. v. 110, p.183-209, 1959

67. GOLDBERG, A. The porphyrias. Historical perspective. Clin. Dermatol. v. 16, p. 189-93, 1998 
68. GOLDBERG, A.; RIMINGTON, C. Fate of porphobilinogen in the rat. Relation to acute porphyria in man. Lancet v.267, p.172-3, 1954

69. GRANDCHAMP, B. Acute intermittent porphyria. Semin. Liver Dis. v. 18, p.17-24, 1998

70. GRANICK, S.; BEALE, S.I. Hemes, chlorophylls, and related compounds: biosynthesis and metabolic regulation. Adv. Enzymol. v. 46, p. 33-203, 1978

71. GRANICK, S.; GILDER, H. Distribution, structure and properties of the tetrapyrroles. Advanc. Enzymol. v. 7, p. 305-68, 1947

72. GRANICK, S.; URATA, G. Increase in activity of $\delta$-amino-levulinic-acid synthetase in liver mitochondria induced by feeding of 3,5dicarbethoxy-1,4-dihydrocollidine. J. Biol. Chem. v. 238, p. 821-7, 1963

73. GROß, U.; JACOB, K., FRANK, M.; DOSS, M.O. Haem precursors and porphobilinogen deaminase in erythrocytes and lymphocytes of patients with acute intermittent porphyria. Cell. Mol. Biol. v. 43, p. 29-35, 1997

74. GROß, U.; SASSA, S.; JACOB, K.; DEYBACH, J-C.; NORDMANN, Y.; FRANK, M.; DOSS, M.O. 5-Aminolevulinic acid dehydratase deficiency porphyria: a twenty-year clinical and biochemical followup. Clin. Chem. v. 44, p. 1892-6, 1998

75. GÜNTHER, H. Die Bedeutung der hämatoporphyrinurie in Physiologie und Pathologie. Ergeb. Allg. Path. Anat. v.20, p. 608-764, 1922 
76. HARDING, A.E. Molecular diagnosis of peripheral neuropathies. Baillières Clin. Neurol. v.4, p. 383-400, 1995

77. HARLEY, V. Two fatal cases of an unusual form of nerve disturbance, associated with dark-red urine, probably due to defective tissue oxidation. Brit. Med. J. v. 2, p. 1169-70, 1890

78. HARPER, C.; BUTTERWORTH, R. Nutritional and metabolic disorders. In GRAHAN, D. I.; LANTOS, P. L., ed. Greenfield's Neuropathology, $6^{\text {a }}$ ed., New York , Arnold, 1997, cap.10, p. 641

79. HELLMAN, E.S.; TSCHUDY, D.P.; BARTTER, F.C. Abnormal electrolyte and water metabolism in acute intermittent porphyria. Amer. J. Med. v. 32, p. 734-45, 1962

80. HERMES-LIMA, M.; CASTILHO, R.F.; VALLE, V.G.R.; BECHARA, E.J.H.; VERCESI, A.E. Calcium-dependent mitochondrial oxidative damage promoted by 5-aminolevulinic acid. Biochimica et Biophysica Acta v. 1180, p. 201-6, 1992

81. HIERONS, R. Acute intermittent porphyria. Postgrad. Med. J. v. 43, p. $605-8,1967$

82. HINDMARSH, J.T. The porphyrias: recent advances. Clin. Chem. v. 32 , p. $1255-63,1986$

83. HINDMARSH, J.T.; OLIVERAS, L.; GREENWAY, D.C. Plasma porphyrins in the porphyrias. Clin. Chem. v.45, p. 1070-6, 1999 
84. HODGSON, G.W.; PONNAMPERUMA, C. Prebiotic porphyrin genesis: Porphyrins from electric discharge in methane, ammonia, and water vapour. Proc. Natl. Acad. Sci. v. 59, p. 22-8, 1968

85. JAFFE, E.K.; VOLIN, M.; BRONSON-MULINS, C.R.; DUNBRACK, R.L.; KERVINEM, J.; MARTINS, J.; QUINLAN, J.F.; SAZINSKY, M.H.; STEINHOUSE, E.M.; YUNY, A.T. An artificial gene for human porphobilinogen synthase allows comparison of an allelic variation implicated in susceptibility to lead poisoning. J. Biol. Chem. v. 275, p. 2619-26, 2000

86. JAMISON, K.R.; WYATT, R.J. Vincent van Gogh's illness. BMJ v. 304, p. 577, 1992

87. JEANS, J.B.; SAVIK, K.; GROSS, C.R.; WEIMER, M.K.; BOSSENMAIER, I.C.; PIERACH, C.A.; BLOOMER, J.R. Mortality in patients with acute intermittent porphyria requiring hospitalisation: a United States case series. American Journal of Medical Genetics v. 65, p. 269-73, 1996

88. KAADA, B.; ROMSLO, I. Use of transcutaneous nerve stimulation in the attacks of acute intermittent porphyria. Int. J. Biochem. v. 17, p. $235-40,1985$

89. KAPPAS, A.; SASSA, S.; ANDERSON, K.E. The porphyrias. In SCRIVER, C.R.; BEAUDET, A.L.; SLY, W.S.; VALLE, D., ed: The metabolic basis of inherited diseases. $5^{\mathrm{a}}$ ed., New York, McGraw Hill, 1983, v. 2, p. 1301-84

90. KAUPPINEN, R. Management of acute porphyrias. Photodermatol. Photoimmunol. Photomed. v.14, p.48-51, 1998 
91. KAUPPINEN, R.; MUSTAJOKI, P. Prognosis of acute intermittent porphyria: occurrence of acute attacks, precipitating factors, and associated diseases. Medicine v. 71, p.1-13, 1992

92. KAUPPINEN, R.; MUSTAJOKI, S., PIHLAJA, H.; PELTONEN, I.; MUSTAJOKI, P. Acute intermittent porphyria in Finland: 19 mutations in the porphobilinogen deaminase gene. Hum. Mol. Genet. v. 4235, p. 215-22, 1995

93. KING, P.H.; BRAGDON, A.C. MRI reveals multiple reversible cerebral lesions in an attack of acute intermittent porphyria. Neurology $\mathrm{v}$. 41, p.1300-2, 1991

94. KLÜVER, H. Porphyrin in relation to the development of the central nervous system. In Proceedings of the First International Neurochemistry Symposium, Magdalen College, Oxford, Academic Press, 1954, p. 137-44, apud TSCHUDY, D.P. et al., 1975, p. 856

95. KNUDSEN, K.B.; SPARBERG, M.; LECOCQ, F. Porphyria precipitated by fasting. New Engl. J. Med. v. 277, p. 350-1, 1967

96. KOSTRZEWSKA, E.; GREGOR, A. Acute hepatic porphyrias. Detection, prophylaxis and treatment. Mater. Med. Pol. v. 28, p. 57, 1996

97. KRAMER, S.; BECKER, D.; VILJOEN, D. Significance of the porphyrin precursors delta-aminolaevulinic acid (ALA) and porphobilinogen (PBG) in the acute attack of porphyria. S. Afr. Med. J. v. 47, p. 1735-8, 1973 
98. KUPFERSCHMIDT, H.; BONT, A.; SCHNORF, H.; LANDIS, T.; WALTER, E.; PETER, J.; KRÄHENBÜHL, S.; MEIER, P.J. Transient cortical blindness and bioccipital brain lesions in two patients with acute intermittent porphyria. Ann. Intern. Med. v. 123 , p. $598-600,1995$

99. LACAZ, P.S.; CAFÉ, A.C.; MOREIRA, M.B.S.; MARTINS, C.F. Porfirias: considerações sobre um caso de porfiria aguda intermitente. J. Bras. Neurol. v. 10, p. 17-75, 1958

100. LAI, C.W.; HUNG, T.; LIN, W.S.J. Blindness of cerebral origin in acute intermittent porphyria. Arch. Neurol. v. 34, p. 310-2, 1977

101. LAMON, J.M.; WITH, T.K.; REDEKER, A.G. The Hoesch test: bedside screening for urinary porphobilinogen in patients with suspected porphyria. Clin. Chem. v. 20, p. 1438-40, 1974

102. LAMON, J.M.; TSCHUDY, D.P. Acute intermittent porphyria. Drugtheraphy v.8 p.115-24, 1978

103. LEVY, J.A.; FANCI, J.L.; DUCHÊNE, G.H; FARIA, J.L.; SARAIVA, S. Porfiria aguda intermitente. Estudo anátomo-patológico de um caso. Arq. Neuro-Psiq. v.16 p.145-50, 1958

104. LINDBERG, R.L.P.; MARTINI, R.; BAUMGARTNER, M.; ERNE, B.; BORG, J.; ZIELASEK, J.; RICKER, K.; STECK, A.; TOYKA, K.V.; MEYER, U.A. Motor neuropathy in porphobilinogen deaminasedeficient mice imitates the peripheral neuropathy of human acute porphyria. J. Clin. Invest. v.103, p. 1127-34, 1999 
105. LINET, M.S.; GRIDLEY, G.; NYRÉN, O.; MELLEMKJAER, L.; OLSEN, J.H.; KEEHN, S.; ADAMI, O.; FRAUMENI Jr., J.F. Primary liver cancer, other malignancies, and mortality risks following porphyria: a cohort study in Denmark and Sweden. American Journal of Epidemiology. v. 149, p. 1010-5, 1999

106. LIP, G.Y.H.; McCOLL, K.E.L.; GOLDBERG, A.; MOORE, M.R. Smoking and recurrent attacks of acute intermittent porphyria. BMJ v. 302, p. 507-8, 1991

107. LITHNER, F. Could attacks of abdominal pain in cases of acute intermittent porphyria be due to intestinal angina? J. Intern. Med. v. 247 , p. $407-9,2000$

108. LOFTUS, L.S.; ARNOLD, W.N. Vincent van Gogh's illness: Acute intermittent porphyria? BMJ v. 303, p. 1589-91, 1991

109. LUNDIN, G.; LEE, J-S.; THUNELL, S.; ANVRET, M. Genetic investigation of the porphobilinogen deaminase gene in Swedish acute intermittent porphyria families. Hum. Genet. v. 100, p. 63-6, 1997

110. MACALPINE, I.; HUNTER, R. The "insanity" of King George III: a classic case of porphyria. Br. Med. J. v. 1, p. 65-71, 1966

111. MAGNUSSEN, C.R.; DOHERTY, J.M.; HESS, R.A.; TSCHUDY, D.P. Grand mal seizures and acute intermittent porphyria. The problem of differential diagnosis and treatment. Neurology v. 25, p. 11215,1975

112. MARCHIORI, P.E.; ASSIS, J.L.; SCAFF, M.; SERRO-AZUL, L.G.; MORAES, E.C.F.; BACHESCHI, L.A.; YASSUDA, N. Tratamento 
da porfiria aguda intermitente com hematina. Registro de caso. Rev. Bras. de Pesquisas Med. e Biol. v.12: p.325-333, 1979

113. MARCHIORI, P.E.; SCAFF, M.; MORAES, E.C.F.; BACHESCHI, L.A.; ASSIS, J.L. Porfirias-considerações a respeito de 26 casos. Rev. Hosp. Clín. Fac. Med. S. Paulo v. 37, p. 101-7, 1982

114. MARKS, G.S.; McCLUSKEY, S.A.; MACKIE, J.E., RIDDICK, D.S.; JAMES, C.A. Interaction of chemicals with cytochrome $P_{450}$ : Implications on the porphyrinogenicity of drugs. Clin. Biochem. v. 22, p. 169-75, 1989

115. MARVER, H.S.; COLLINS, A.; TSCHUDY, D.P.; RECHCIGL, M., Jr. $\delta$ Aminolevulinic acid synthetase. II. Induction in rat liver. J. Biol. Chem. v. 241, p. 4323-9, 1966

116. MASON, V.R.; COURVILLE, C.; ZISKIND, E. The porphyrins in human disease. Medicine (Baltimore) v.12, p. 355-439, 1933

117. MAUZERALL, D.; GRANICK, S. The occurrence and determination of $\delta$ - aminolevulinic acid and porphobilinogen in urine. J. Biol. Chem. v. 219, p. 435-46, 1956

118. MAXWELL, J.D.; MEYER, U.A. Effect of lead on hepatic $\delta$ aminolevulinic acid for drug sensitivity in acute intermittent porphyria. Europ. J. Clin. Invest., v. 6, p. 373-9, 1976

119. McCOLL, K.E.L.; MOORE, M.R.; THOMPSON, G.G., GOLDBERG, A. Treatment with haematin in acute hepatic porphyria. QJM v. 198, p. $161-74,1981$ 
120. McENEANEY, D.; HAWKINS, S.; TRIMBLE, E.; SMYE, M. Porphyric neuropathy: a rare and often neglected differential diagnosis of Guillain-Barré syndrome. J. Neurol. Sci. v. 114, p. 231-3, 1993

121. MEDEIROS, M.H.G.; MARCHIORI, P.E.; BECHARA, E.J.H. Superoxide dismutase, glutathione peroxidase, and catalase activities in the erythrocytes of patients with acute intermittent porphyria. Clin. Chem. v.28, p. 242-3, 1982

122. MEISLER, M.; WANNER, L.; EDDY, R.E.; SHOWS, T.B. The UPS locus encoding uroporphyrinogen I synthase is located on human chromossome 11. Biochem. Biophys. Res. Commun. v. 95, p. $170-6,1980$

123. MEYER, U.A.; SCHMID, R. Intermittent acute porphyria: the enzymatic defect. Res. Publ. Assoc. Nerv. Ment. Dis. v. 53, p. 211-24, 1974

124. MEYER, U.A.; SCHUURMANS, M.M.; LINDBERG, R.L.P. Acute porphyrias: pathogenesis of neurological manifestations. Semin. Liver Dis. v. 18, p. 43-52, 1998

125. MEYER, U.A.; STRAND, J.; DOSS, M.; REES, A.C.; MARVER, H.S. Intermittent acute porphyria: demonstration of a genetic defect in porphobilinogen metabolism. N. Engl. J. Med. v. 286, p. 1277-82, 1972

126. MINDER, E.I. Measurement of 5-aminolaevulinic acid by reversed phase HPLC and fluorescence detection. Clin. Chim. Acta v. 161, p. 11-8, 1986 
127. MONTEIRO, H.P.; ABDALLA, D.S.P.; FALJONI-ALÁRIO, A.; BECHARA, E.J.H. Generation of active oxygen species during coupled autoxidation of oxyhemoglobin and $\delta$-aminolevulinic acid. Biochim. Biophys. Acta v. 881, p. 100-6, 1986

128. MOORE, M.R. The biochemistry of heme synthesis in porphyria and in the porphyrinurias. Clin. Dermatol. v. 16, p.203-23, 1998

129. MOORE, M.R.; GRAHAM, D.J.M. Monopyrroles in porphyria, psychosis and lead exposure. Int. J. Biochem. v.12, p.827-32, 1980

130. MOORE, M.R.; HIFT, J.R. Drugs in the acute porphyrias-toxicogenetic diseases. Cell. Mol. Biol. v. 43, p. 89-94, 1997

131. MOORE, M.R.; McCOLL, K.E.L.; GOLDBERG, A. The effects of alcohol on porphyrin biosynthesis and metabolism. Clin. Bioch. Alcohol v. 1, p. 161-87, 1984

132. MUSTAJOKI, P.; KAUPPINEN, R.; LANNFELT, L.; LILIUS, L.; KOISTINEN, J. Frequency of low erytrocyte porphobilinogen deaminase activity in Finland. J. Intern. Med. v. 231, p. 389-95, 1992

133. MUSTAJOKI, P.; NORDMANN, Y. Early administration of heme arginate for acute porphyric attacks. Arch. Intern. Med. v. 153, p. 2004-8, 1993

134. MUSTAJOKI, P.; SEPPÄLÄINEN, A.M. Neuropathy in latent hereditary hepatic porphyria. Brit. Med. J. v. 2, p. 310-2, 1975 
135. NAMBA, H.; NARAHARA, K.; TSUJI, K.; YOKOYAMA, Y.; SEINO, Y. Assignment of human PBG deaminase to 11q24.1-q24.2 by in situ hybridization and gene dosage studies. Cytogenet. Cell. Genet. v. 57, p. $105-8,1991$

136. NORDMANN, Y.; DEYBACH, J.C. Porphyries hépatiques: médicaments autorisés et interdits. Presse Med. v. 16, p. 327-30, 1987

137. NORDMANN, Y.; PUY, H.; DEYBACH, J.C. Les porphyries hépatiques. Rev. Méd. Interne v. 20, p. 333-40, 1999

138. ORRENIUS, S.; BURKITT, M.J.; KASS, G.E.N.; DYPBUKT, J.M.; NICOTERA, P. Calcium ions and oxidative cell injury. Ann. Neurol. v. 32, S33-42, 1992

139. ORTEGA, X.M.; FERNANDEZ, C.W.; IBARRA, T.L.; NAVARRO, N.M.; ARMAS-MERINO R. Crisis porfirica. Experiencia com 30 episodios. Medicina (Buenos Aires) v. 59, p. 23-7, 1999

140. PARSONAGE, M.J.; TURNER, J.W.A. Neuralgic amyotrphy - the shoulder-girdle syndrome. Lancet v. 1, p. 973-8, 1948

141. PATIENCE, D.A.; BLACKWOOD, D.H.R.; McCOLL, K.E.L.; MOORE, M.R. Acute intermittent porphyria and mental illness - a family study. Acta Psych. Scand. v. 89, p.262-7, 1994

142. PERLROTH, M.G.; TSCHUDY, D.P.; HARVEY, S.M.; BERARD,C.W.; ZEIGEL, R.F.; RECHCIGL, M.; COLLINS, A. Acute intermittent porphyria: new morphologic changes and biochemical findings. Am. J. Med. v. 41, p. 149-62, 1966 
143. PERLROTH, M.G.; TSCHUDY, D.P.; WAXMAN, A.; ODELL, W.D. Abnormalities of growth hormone regulation in acute intermittent porphyria. Metabolism v. 1, p. 87-90, 1967

144. PETERS, H.A. Acute hepatic porphyria. In JOHNSON, R.T.; GRIFFIN, J.W. Current Therapy In Neurologic Disease, $4^{\text {a }}$. ed., Missouri, Mosbi Year Book, 1993, p. 317-22

145. PETERS, H.A.; CRIPPS, D.J.; GOCMEN, A.; BRYAN, G.; ERTÜRK, E.; MORRIS, C. Turkish epidemic hexachlorobenzene porphyria. A 30-year study. Ann. NY Acad. Sci. v. 514, p.183-90, 1987

146. PETERS, H.A.; CRIPPS, D.J.; REESE, H.H. Porphyria: theories of etiology and management. Int. Rev. Neurobiol. v. 16, p. 301-55, 1974

147. PUY, H.; AQUARON, R.; LAMORIL, J.; ROBRÉAU, A.M.; NORDMANN, Y.; DEYBACH, J.C. Acute intermittent porphyria: rapid molecular diagnosis. Cell. Mol. Biol. v. 43, p. 37-45, 1997

148. PUY, H.; DEYBACH, J.C.; BOGDAN, A.; CALLEBERT, J.; BAUMGARTNER, M.; VOISIN, P.; NORDMANN, Y.; TOUITOU, Y. Increased $\delta$-aminolevulinic acid and decreased pineal melatonin production. A common event in acute porphyria studies in the rat. J. Clin. Invest. v. 97, p. 104-10, 1996

149. PUY, H.; DEYBACH, J.C.; LAMORIL, J.; ROBRÉAU, A.M.; da SILVA, V.; GOUYA, L.; GRANDCHAMP, B.; NORDMANN, Y. Molecular epidemiology and diagnosis of PBG deaminase gene defects in 
acute intermittent porphyria. Am. J. Hum. Genet v. 60, p. 137383, 1997

150. RATNAIKE, S.; BLAKE, D. The diagnosis and follow-up of porphyria. Pathology v. 27, p. 142-53, 1995

151. RANKING, J.E.; PARDINGTON, G.L. Two cases of haematoporphyrin in the urine. Lancet v. 2, p. 607-9, 1890

152. RIDLEY, A. ; CAVANAGH, J.B. Exercise as a factor in the neuropathy of porphyria. Lancet v. 2, p. 87-8, 1972

153. RIDLEY, A. The neuropathy of acute intermittent porphyria. Q. J. Med. v. 38, p. $307-33,1969$

154. RIDLEY, A. Porphyric neuropathy. In DYCK, P.J.; THOMAS, P.K.; GRIFFIN, J.W.; LOW, P.A.; PODUSLO, J.F., ed. In Peripheral Neuropathy. $2^{\text {a }}$ ed. Philadelphia, WB Saunders, 1984, v. 2, p.1704-16

155. RIMINGTON, C. Patterns of porphyrin excretion and their interpretation. S. Afr. J. Lab. Clin. Med. v. 9, p. 255-61, 1963

156. RIMINGTON, C. Was Hippocrates the first to describe a case of acute porphyria? Int. J. Biochem. v. 10, p. 1351-2, 1993

157. ROCHA, M.E.M.; BANDY, B.; COSTA, C.A.; BARROS, M.P.B.; PINTO, A.M.P.; BECHARA, E.J.H. Iron mobilization by succinilacetone methyl ester in rats. A model study for hereditary tyrosinemia and porphyrias characterized by 5- aminolevulinic acid overload. Free Rad. Res. v. 32, p. 343-53, 2000 
158. ROCHA, M.E.M.; FERREIRA, A.M.D.C.; BECHARA, E.J.H. Roles of phosphate and an enoyl radical in ferritin iron mobilization by 5 aminolevulinic acid. Free Rad. Biol. \& Med. v. 29, 2000. No prelo

159. ROSE, J.A.; HELLMAN, E.S.; TSCHUDY, D.P. Effect of diet on the induction of experimental porphyria. Metabolism v. 10, p. 514-21, 1961

160. ROSIPAL, R.; PUY, H.; LAMORIL, J.; MARTASEK, P.; NORDMANN, Y.; DEYBACH, J.C. Molecular analysis of porphobilinogen (PBG) deaminase gene mutations in acute intermittent porphyria: first study in patients of Slavic origin. Scand. J. Clin. Lab. Invest. v. 57 , p. $217-24,1997$

161. ROSSI, E. Increased fecal porphyrins in acute intermittent porphyria. Clin. Chem. v. 45, p. 281-3, 1999

162. SACHS, P. Ein Fall von akuter Porphyrie mit hochgrädiger Muskelatrophie. Klin. Wschr. v.10, p. 1123-25, 1931

163. SAINT, E.G.; CURNOW, D.H. Porphyria in western Australia. Lancet v.1, p. 133-6, 1962

164. SALGADO, P.E.T. Controle e diagnóstico laboratorial da intoxicação pelo chumbo. São Paulo, 1976. Dissertação (Mestrado). Faculdade de Ciências Farmacêuticas da Universidade de São Paulo

165. SANO, S.; RIMINGTON, C. Excretions of various porphyrins and their corresponding porphyrinogens by rabbits after intravenous injections. Biochem. J. v. 86, p. 203-12, 1963 
166. SASSA, S.; KAPPAS, A. Molecular aspects of inherited porphyrias. J. Intern. Med. v. 247, p. 169-178, 2000

167. SASSA, S.; SOLISH, G.; LEVERE, R.D.; KAPPAS, A. Expression of the gene defect of acute intermittent porphyria in cultured human skin fibroblasts and amniotic cells: prenatal diagnosis of the porphyric trait. J. Exp. Med. v. 142, p. 722-31, 1975

168. SCHMID, R.; SCHWARTZ, S.; WATSON, C.J. Porphyrin content of bone marrow and liver in the various forms of porphyria. A.M.A. Arch. Intern. Med. v. 93, p. 167-90, 1954

169. SCHOENFELD, N.; SZTERN, M.; MAMET, R. Yeast, creatinine and false diagnosis of porphyria. Cell. Mol. Biol. v. 43 , p.81-8, 1997

170. SCHREIBER, W.E. A molecular view of the neurologic porphyrias. Clin. Lab. Med. v. 17, p. 73-83, 1997

171. SCHREIBER, W.E.; JAMANI, A.; PUDEK, M.R. Screening tests for porphobilinogen are insensitive: The problem and its solution. Am. J. Clin. Pathol. v. 92, p. 644-9, 1989

172. SHENHAV, S.; GEMER, O.; SASSOON, E.; SEGAL, S. Acute intermittent porphyria precipitated by hyperemesis and metoclopramide treatment in pregnancy. Acta. Obstet. Gynecol. Scand. v. 76 , p. $484-5,1997$

173. SINNOTT, J.L. The laboratory investigation of the porphyrin disorders. A review. Med. Lab. Sci. v. 33, p. 133-53, 1976 
174. STEIN, J.A.; TSCHUDY, D.P. Acute intermittent porphyria. A clinical and biochemical study of 46 patients. Medicine v. 49, p.1-16, 1970

175. STOKVIS, B.J. Over twee zeldzame kleurstoffen in urine van zieken. Need. Tidj. Geneesk. v.13, p. 409-17, 1889, apud SUAREZ, J.I. et al., 1997, p. 1678

176. STRIK, W.K. The psychiatric illness of Vincent van Gogh. Nervenartz v. 68, p. $401-9,1997$

177. SUAREZ, J.I.; COHEN, M.L.; LARKIN, J.; KERNICH, M.S.N.; HRICIK, D.E.; DAROFF, R.B. Acute intermittent porphyria: Clinicopathological correlation. Report of a case and review of the literature. Neurology v.48, p. 1678-83, 1997

178. SUSA, S.; DAIMON, M.; MORITA, Y.; KITAGAWA, M.; HIRATA, A.; MANAKA, H.; SASAKI, H.; KATO, K. Acute intermittent porphyria with central pontine myelinolysis and cortical laminar necrosis. Neuroradiology v. 41, p. 835-9, 1999

179. SZE, GORDON. Cortical lesions in acute intermittent porphyria. Ann. Intern. Med. v. 125, p. 422-3, 1996

180. SWEENEY, V.P.; PATHAK, M.A.; ASBURY, A.K. Acute intermittent porphyria. Increased ALA synthetase activity during an acute attack. Brain v. 93, p. 369-80, 1970

181. TADDEINI, L.; WATSON, C.J. The clinical porphyrias. Sem. Hemat. v. 5, p. 335-69, 1968 
182. THOMAS, P.K. The morfological basis for alterations in nerve conduction in peripheral neuropathy. Proc. R. Soc. Med. v. 64, p. 295-8, 1971

183. THUNELL, S.; ANDERSSON, D.; HARPER, P.; HENRICHSON, A.; FLODERUS, Y.; LINDH, U. Effects of administration of antioxidants in acute intermittent porphyria. Eur. J. Clin. Chem. Biochem. v. 35, p.427-33, 1997

184. TISHLER, P.V. The effect of the therapeutic drugs and other pharmacologic agents on activity of porphobilinogen deaminase, the enzyme that is deficient in intermittent acute porphyria. Life Sciences v. 65 , p. 207-14, 1999

185. TISHLER, P.V.; WOODWARD, B.; O'CONNOR, J.; HOLBROOK, D.A.; SEIDMAN, L.J.; HALLETT, M.; KNIGHTON, D.J. High prevalence of acute intermittent porphyria in a psychiatric patient population. Am. J. Psychiatry v. 142, p. 1430-6, 1985

186. TOMOKUNI, K.; OGATA, M. Simple method for determination of urinary $\delta$ - aminolevulinic acid as an index of lead exposure. Clin. Chem. v. 18, p.1534-6, 1972

187. TSCHUDY, D.P. Porphyrin metabolism and the porphyrias. In BONDY, K.P.; ROSENBERG, L.E. Duncan's Diseases of Metabolism. $7^{\text {a }}$. ed., Philadelphia, Saunders, 1974 , p. $775-824$

188. TSCHUDY, D.P.; PERLROTH, M.G.; MARVER, H.S.; COLLINS, A.; HUNTER, G.W., Jr., RECHCIGL, M., Jr. Acute intermittent porphyria: the first "overproduction disease" localised to a specific enzyme. Proc. Natl. Acad. Sci. v. 53, p. 841-7, 1965 
189. TSCHUDY, D.P.; VALSAMIS, M.; MAGNUSSEN, C.R. Clinical and selected research aspects. Ann. Int. Med. v. 83, p. 851-64, 1975

190. TSCHUDY, D.P.; WELLAND, F.H.; COLLINS, A.; HUNTER, G.W., Jr. The effect of carbohydrate feeding on the induction of $\delta$ aminolevulinic acid synthetase. Metabolism v. 13, p. 396-406, 1964

191. VLIET, A. V.; BAST, A. Effect of oxidative stress on receptors and signal transmission. Chem. Biol. Interactions v. 85 , p. 95-116, 1992

192. VOSWINCKEL, P. A constant source of surprises: Acute porphyria. Two cases reported by Hippocrates and Sigmund Freud. Hist. Psychiatry v. 1, p. 159-68, 1990

193. WALDENSTRÖM, J. Studien über porphyrie. Acta Med. Scandinav. supl. 82 , p. $67-151,1937$

194. WALDENSTRÖM, J. Neurological symptoms caused by so-called acute porphyria. Acta Psychiatr. Neurol. v. 14, 375-9, 1939

195. WALDENSTRÖM, J. The porphyrias as inborn errors of metabolism. Amer. J. Med. v. 22, p. 758-73, 1957

196. WALDENSTRÖM, J.; VAHLQUIST, B. Studies on the excretion of porphobilinogen in patients with so-called acute porphyria. Acta Med. Scandinav. v. 117, p. 1-14, 1944

197. WATSON, C.J. Porphyria. Adv. Intern. Med. v. 6, p. 235-99, 1954 
198. WATSON, C.J: Pursuit of the purple. JAMA v. 197, p. 126-32, 1966

199. WATSON, C.J.; DHAR, G.J.; BOSSENMAIER, I.; CARDINAL, R.; PETRYKA, Z.J. Effect of hematin in acute porphyric relapse. Ann. Intern. Med. v. 79, p. 80-92, 1973

200. WATSON, C.J.; RUNGE, W.; BOSSENMAIER, I. Increased urinary porphobilinogen and uroporphyrin after administration of stilboestrol in a case of latent porphyria. Metabolism v. 11, p. 1129-33, 1962

201. WATSON, C.J.; SCHWARTZ, S. A simple test for urinary porphobilinogen. Proc. Soc. Exper. Biol. Med. v. 67, p. 393-4, 1941.

202. WELLAND, F.H.; HELLMAN, E.S.; COLLINS, A.; HUNTER, G.W., Jr.; TSCHUDY, D.P. Factors affecting the excretion of porphyrin precursors by patients with acute intermittent porphyria. II. The effect of ethinyl estradiol. Metabolism v. 13, p. 251-8, 1964

203. WELLAND, F.H.; HELLMAN, E.S.; GADDIS, E.M.; COLLINS, A.; HUNTER, G.W., Jr.; TSCHUDY, D.P. Factors affecting the excretion of porphyrin precursors by patients with acute intermittent porphyria. I. The effect of diet. Metabolism v. 13, p. 232-50, 1964

204. WHATLEY, S.D.; ROBERTS, A.G.; ELDER, G.H. De novo mutation and sporadic presentation of acute intermittent porphyria. Lancet v. 346, p. $1007-8,1995$ 
205. WINDEBANK, A.J.; BONKOVSKY, H.L. Porphyric neuropathy. In DYCK, P.J., THOMAS, P.K., GRIFFIN, J.W., LOW, P.A., PODUSLO, J.F., ed. Peripheral Neuropathy. $3^{\text {a }}$ ed. Philadelphia, WB Saunders, 1993, v. 2, p. 1161-8

206. YEUNG-LAIWAH, A.C.Y.; MACPHEE, G.J.A.; BOYLE, P.; MOORE, M.R.; GOLDBERG, A. Autonomic neuropathy in acute intermittent porphyria. J. Neurol. Neurosurg. Psychiatr. v. 48, p. 1025-30, 1985

207. YEUNG-LAIWAH, A.C.Y.; MOORE, M.R.; GOLDBERG, A. Pathogenesis of acute porphyria. Q.J. Med. (New Series) v. 63, p. 377-92, 1987

208. YOO, H-W; WARNER, C.A.; CHEN, C.H.; DESNICK, R.J. Hydroxymethylbilane synthase: Complete genomic sequence and amplifiable polymorphisms in the human gene. Genomics v. 15, p. 21-9, 1993

209. ZIMMERMAN, T.S.; MCMILLIN, J.M.; WATSON, C.J. Onset of manifestations of hepatic porphyria in relation to the influence of female sex hormones. Arch. Int. Med. v. 118, p. 229-40, 1966 
De acordo com:

UNIVERSIDADE DE SÃO PAULO. Faculdade de Medicina. Serviço de Biblioteca e Documentação. Estrutura e apresentação de dissertações e teses. Elaborado por Anneliese Carneiro da Cunha. São Paulo, Serviço de Biblioteca e Documentação, 1996.

Abreviaturas dos títulos dos periódicos de acordo com LIST OF JOURNALS INDEXED IN INDEX MEDICUS. 